\title{
Summertime calcium carbonate undersaturation in shelf waters of the western Arctic Ocean - how biological processes exacerbate the impact of ocean acidification
}

\author{
N. R. Bates ${ }^{1}$, M. I. Orchowska ${ }^{2}$, R. Garley ${ }^{1}$, and J. T. Mathis ${ }^{3}$ \\ ${ }^{1}$ Bermuda Institute of Ocean Sciences, St. Georges, Bermuda \\ ${ }^{2}$ Institute of Oceanology, Polish Academy of Sciences, Sopot, Poland \\ ${ }^{3}$ National Oceanic and Atmospheric Administration, Pacific Marine Environmental Lab, Seattle, WA, USA \\ Correspondence to: N. R. Bates (nick.bates@bios.edu)
}

Received: 24 August 2012 - Published in Biogeosciences Discuss.: 16 October 2012

Revised: 24 June 2013 - Accepted: 24 June 2013 - Published: 6 August 2013

\begin{abstract}
The Arctic Ocean accounts for only $4 \%$ of the global ocean area, but it contributes significantly to the global carbon cycle. Recent observations of seawater $\mathrm{CO}_{2}-$ carbonate chemistry in shelf waters of the western Arctic Ocean, primarily in the Chukchi Sea, from 2009 to 2011 indicate that bottom waters are seasonally undersaturated with respect to calcium carbonate $\left(\mathrm{CaCO}_{3}\right)$ minerals, particularly aragonite. Nearly $40 \%$ of sampled bottom waters on the shelf have saturation states less than one for aragonite (i.e., $\Omega_{\text {aragonite }}<1.0$ ), thereby exposing the benthos to potentially corrosive water for $\mathrm{CaCO}_{3}$-secreting organisms, while $80 \%$ of bottom waters present had $\Omega_{\text {aragonite }}$ values less than 1.5. Our observations indicate seasonal reduction of saturation states $(\Omega)$ for calcite $\left(\Omega_{\text {calcite }}\right)$ and aragonite $\left(\Omega_{\text {aragonite }}\right)$ in the subsurface in the western Arctic by as much as 0.8 and 0.5 , respectively. Such data indicate that bottom waters of the western Arctic shelves were already potentially corrosive for biogenic and sedimentary $\mathrm{CaCO}_{3}$ for several months each year. Seasonal changes in $\Omega$ are imparted by a variety of factors such as phytoplankton photosynthesis, respiration/remineralization of organic matter and air-sea gas exchange of $\mathrm{CO}_{2}$. Combined, these processes either increase or enhance in surface and subsurface waters, respectively. These seasonal physical and biological processes also act to mitigate or enhance the impact of Anthropocene ocean acidification (OA) on $\Omega$ in surface and subsurface waters, respectively. Future monitoring of the western Arctic shelves is warranted to assess the present and future impact of ocean acidification and seasonal physico-biogeochemical processes on $\Omega$ values and Arctic marine ecosystems.
\end{abstract}

\section{Introduction}

The release of anthropogenic carbon dioxide $\left(\mathrm{CO}_{2}\right)$ to the atmosphere and its uptake by the global ocean have significant implications for ocean chemistry and marine organisms and ecosystems. While the global ocean remains generally mildly alkaline at present, the uptake of anthropogenic $\mathrm{CO}_{2}$ from the atmosphere into the ocean changes the chemical equilibria of the $\mathrm{CO}_{2}$-carbonate system of seawater, resulting in gradual acidification of seawater in a process termed ocean acidification (OA; Caldeira and Wickett 2003, 2005; Doney et al., 2009; Feely et al., 2009). As the $\mathrm{CO}_{2}$ content of seawater increases in response to uptake of anthropogenic $\mathrm{CO}_{2}$, readjustment of seawater $\mathrm{CO}_{2}$-carbonate equilibria results in the reduction of $\mathrm{pH}$, carbonate ion concentration $\left[\mathrm{CO}_{3}^{2-}\right]$ and saturation state $(\Omega)$ of calcium carbonate $\left(\mathrm{CaCO}_{3}\right)$ minerals such as calcite (i.e., $\left.\Omega_{\text {calcite }}\right)$ and aragonite (i.e., $\Omega_{\text {aragonite }}$ ). Such changes have been observed in the open ocean over the past thirty years, with the $\mathrm{CO}_{2}$ partial pressure $\left(\mathrm{pCO}_{2}\right)$ of surface seawater increasing by $>30 \%$, while $\mathrm{pH}$ has decreased by $\sim 0.1$ along with $\left[\mathrm{CO}_{3}^{2-}\right]$ and $\Omega$ values for $\mathrm{CaCO}_{3}$ minerals (Bates and Peters, 2007; SantanaCasiano et al., 2007; Dore et al., 2009; Gonzalez-Davila et al., 2010; Olafsson et al., 2009; Byrne et al., 2010; Bates et al., 2012). In the open ocean of the North Pacific Ocean, uptake of anthropogenic $\mathrm{CO}_{2}$ has been shown to reduce the saturation state of $\mathrm{CaCO}_{3}$ minerals, with the result that the lysocline depth (where $\Omega=1$ ) has shoaled by up to $100 \mathrm{~m}$ (Feely et al., 2004). In the coastal ocean, upwelling of $\mathrm{CO}_{2}$ rich subsurface waters has also been shown to bring low-pH 
and $-\Omega$ waters onto adjacent shelves (e.g., Feely et al., 2008; Fassbender et al., 2011; Mathis et al., 2012).

Assessment of the future impact of ocean acidification on seawater $\mathrm{CO}_{2}$-carbonate chemistry such as $\mathrm{pH}$ and $\Omega$ values for $\mathrm{CaCO}_{3}$ minerals, and its implication for calcifying marine organisms and ecosystems, remains highly uncertain at present. A growing number of experimental and field ocean acidification studies show a variety of responses of marine organisms to increased $p \mathrm{CO}_{2}$ and reduced $\mathrm{pH} / \Omega /\left[\mathrm{CO}_{3}^{2-}\right]$ conditions, especially amongst those taxa such as hard corals, echinoderms, bivalves and mollusks that secrete biogenic $\mathrm{CaCO}_{3}$ as shells, skeletons or framework structures (e.g., Buddemeier et al., 2004; Fabry et al., 2008; Doney et al., 2009; Smith, 2009; Büdenbender et al., 2011; Ries, 2011). There is much variability in response to OA even within individual taxa depending on life stage and other physico-biogeochemical factors such as light and nutrient concentrations (e.g., Andersson et al., 2011; Ries, 2011). Seawater with low pH (e.g., <7.7-7.9 in typical seawater) and $\mathrm{CaCO}_{3}$ saturation states less than one (i.e., $\Omega<1$ ) is potentially corrosive to biogenic and sedimentary forms of $\mathrm{CaCO}_{3}$ such as calcite, high-Mg calcite and aragonite. Ocean acidification thus increases the potential for dissolution of $\mathrm{CaCO}_{3}$ (Andersson et al., 2010) particularly in shallow shelf environments where dissolution of calcareous sediments can alter the buffer capacity of waters overlying such sediments. However, despite the emergence of ocean acidification as a potential problem of global significance, integrated studies of the interaction and feedbacks between ocean acidification, seawater $\mathrm{CO}_{2}$-carbonate chemistry, and natural/anthropogenically influenced physico-biogeochemical processes are in their infancy, particularly in the coastal ocean.

The Arctic Ocean - including the deep central basin and surrounding shallow shelf seas - has been identified as potentially vulnerable to the impacts of ocean acidification (e.g., Orr et al., 2005; Yamamoto-Kawai et al., 2009; Steinacher et al., 2009; Bates and Mathis, 2009; Anderson et al., 2011). Recent observations, syntheses and model studies indicate that naturally low temperatures, $\mathrm{pH}$ and $\Omega$ values of surface waters in the Arctic Ocean are conducive to earlier onset of ocean acidification this century - especially given anticipated further release of anthropogenic $\mathrm{CO}_{2}$ to the atmosphere and its uptake by the global ocean (Solomon et al., 2007) - when compared to other open-ocean and coastal waters (e.g., Orr et al., 2005; Steinacher et al., 2009). The impact of ocean acidification on the Arctic Ocean is also likely to be highly synergistic with environmental changes associated with warming, rapid sea-ice loss, changes in seaice meltwater/freshwater inputs to the Arctic, and increased coastal erosion (e.g., ACIA, 2005; Serreze and Francis, 2006; Maslanik et al., 2007; McGuire et al., 2006, 2009; Arrigo et al., 2008; Pabi et al., 2008; Wang and Overland, 2009).

Assessment of the present and future impact of ocean acidification in the Arctic Ocean is complicated by contradictory responses and feedbacks in response to change in the physical properties (e.g., circulation, warming, sea-ice loss) and biogeochemical processes (e.g., nutrient supply, rates of primary production and respiration, ecological changes) within the region (Bates and Mathis, 2009). Field expeditions are difficult to conduct in the Arctic, but, nonetheless, there is growing evidence that low $\mathrm{pH}$ and $\Omega(<1)$ conditions exist in the Arctic Ocean at present. In the Arctic Ocean, waters that are undersaturated with respect to $\mathrm{CaCO}_{3}$ minerals (i.e., low $\Omega$ values $<1$ ) have been observed in the subsurface halocline layer of the central basin waters for both calcite and aragonite (Jutterström and Anderson, 2005; Yamamoto-Kawai et al., 2009; Chierici and Fransson, 2009). Similarly, low $\Omega$ values $(<1)$ for both calcite and aragonite, and reduced buffering capacity of surface waters due to sea-ice melt water, have also been observed in the central basin during summertime (Yamamoto-Kawai et al., 2009). On the surrounding polar shelves, low- $\Omega$ waters that are potentially corrosive to $\mathrm{CaCO}_{3}$ (i.e., $\Omega<1$ ) have been seasonally observed in several regions (during the sea-ice-free summertime), including (1) slope waters of the northern Chukchi Sea (e.g., Bates et al., 2009) and Beaufort Sea (Mathis et al., 2012); (2) in outflow waters of the Arctic in the Canadian Arctic Archipelago (Azetsu-Scott et al., 2010); and (3) as far south as the Bering Sea shelf (Mathis et al., 2009, 2011a, b).

In this study, we assess the present state of $\mathrm{CaCO}_{3}$ saturation states, expressed as $\Omega_{\text {calcite }}$ and $\Omega_{\text {aragonite }}$ values, for surface and subsurface waters across the western Arctic Ocean (Fig. 1). This includes the following regions: (1) the Pacific Ocean-influenced "inflow" shelf of the Chukchi Sea (Carmack and Wassmann, 2006); (2) "interior" shelves of the eastern East Siberian Sea (ESS) and western Beaufort Sea that are highly influenced by internal processes such as river freshwater inputs; and (3) the southern region of the deep Canada Basin (Fig. 1). We use data collected as part of the recent RUSALCA (Russian-American Long-Term Census of the Arctic) and ICESCAPE (Impacts of Climate on the EcoSystems and Chemistry of the Arctic Pacific Environment) expeditions to the western Arctic Ocean from 2009 to 2011. These data are used to assess whether shelf bottom waters of the western Arctic are potentially seasonally corrosive to $\mathrm{CaCO}_{3}$ minerals. In the period of 2002-2004, repeat seasonal observations during the Shelf-Basin Interactions (SBI) project showed that $\mathrm{pH}$ values were lower than 8.0 and values for $\Omega_{\text {aragonite }}$ were $<1$ in subsurface waters on the northern slope of the Chukchi Sea but not across the shelf region (Bates et al., 2009). Here, we examine using seawater $\mathrm{CO}_{2}-$ carbonate data whether bottom waters with low $\mathrm{pH}$ and $\Omega$ are present across much of the shelf areas of the western Arctic Ocean, thereby providing an assessment of the present-day seasonal exposure of the seafloor benthos to bottom waters that are corrosive for $\mathrm{CaCO}_{3}$ shells and skeletons.

Furthermore, we examine the interactions and feedbacks between seawater $\mathrm{CO}_{2}$-carbonate chemistry and physical, biological and chemical processes in the western Arctic Ocean. 


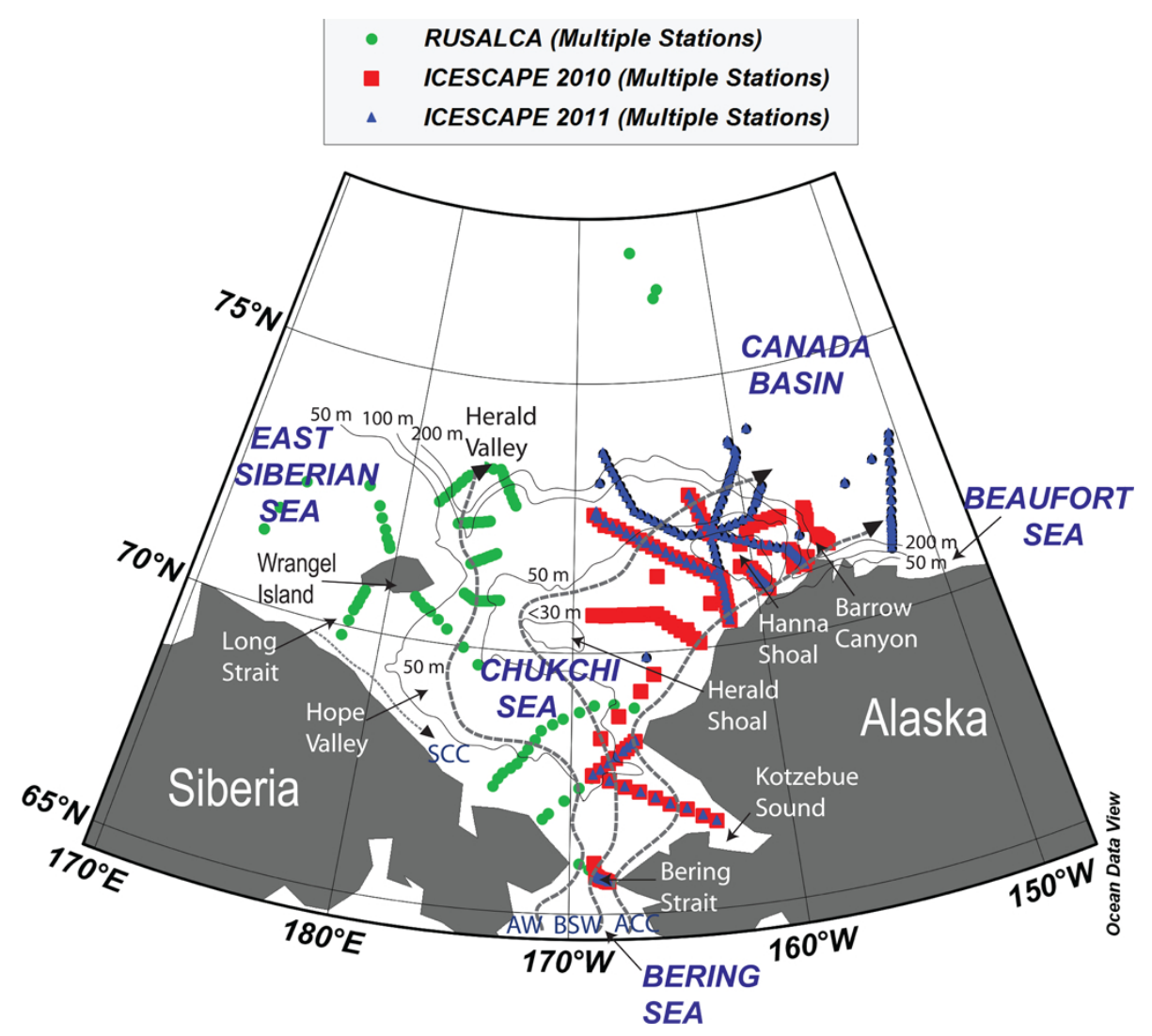

Fig. 1. Map of the western Arctic Ocean showing the stations occupied during the cruises according to the cruise year: RUSALCA 2009 (4-29 September 2009; green); ICESCAPE 2010 (18 June to 16 July 2010; red symbol) and ICESCAPE 2011(28 June to 24 July 2011; blue symbol). Approximate streamlines (bold dashed lines) of Alaskan Coastal Current (ACC), Bering Shelf Water (BSW) and Anadyr Water (AW) are shown. The intermittent flow of the Siberian Coastal Current (SCC) through Long Strait into the Chukchi Sea is also shown.

While many studies have examined the impact of physical processes (e.g., warming/cooling, circulation) and the biological pump (e.g., production, respiration, calcification) on dissolved inorganic carbon (DIC), total alkalinity (TA) and $p \mathrm{CO}_{2}$, particularly in coastal environments, there have been far fewer studies of impacts on $\mathrm{pH}$ and $\mathrm{CaCO}_{3}$ saturation states. The Chukchi Sea has rare characteristics for a coastal shelf sea. Physiogeographically, it is an inflow shelf (sensu Carmack and Wassmann, 2006) with a primarily unidirectional water flow northward towards the pole. It is highly influenced by seasonal sea-ice cover and river freshwater inputs and has high nutrient supply and rates of primary production during the seasonally sea-ice-free period. In this region, multiple physico-biogeochemical processes significantly impact seawater $\mathrm{CO}_{2}$-carbonate chemistry (e.g., $p \mathrm{CO}_{2}, \mathrm{pH}$ and $\Omega$ ) and include the following: marine ecosystem photosynthesis and respiration (or net community production that includes primary production and remineralization of organic carbon), air-sea $\mathrm{CO}_{2}$ gas exchange, warming and sea-ice loss, and changes in the inputs of terrestrial freshwater and organic carbon. When integrated, these processes act to either mitigate or enhance the impact of an- thropogenic ocean acidification - resulting from uptake of anthropogenic $\mathrm{CO}_{2}$ from the atmosphere - in surface and subsurface waters, respectively, of the Arctic Ocean.

\section{Methods}

\subsection{Sampling}

Several thousand seawater carbonate chemistry samples were collected in total from three summertime cruises from 2009 to 2011 in the western Arctic Ocean from multiple CTDhydrocast stations across the shelves of the Chukchi Sea (including Bering Strait), eastern East Siberian Sea, western Beaufort Sea, and deep Canada Basin (Fig. 1). The shipboard expeditions included the following cruises: (1) RUSALCA 2009 (4-29 September 2009); (2) ICESCAPE 2010 (18 June to 16 July 2010); and (3) ICESCAPE 2011 (28 June to 24 July 2011). At each CTD-hydrocast station, seawater samples were collected for TA and DIC, as well as complementary data (e.g., temperature, salinity, inorganic nutrients). Samples for TA and DIC were collected according to Dickson et al. (2007). 


\subsection{Sample analyses}

Samples from the RUSALCA 2009 cruise were analyzed at the Bermuda Institute of Ocean Sciences (BIOS), while ICESCAPE cruise samples were analyzed on board (TA in 2010; TA and DIC in 2011). Replicate samples from the ICESCAPE cruises were also analyzed at BIOS. TA and DIC analyses followed methods described by Dickson et al. (2007). The TA of seawater samples was determined by a highly precise $\left(<1-1.5 \mu \mathrm{mol} \mathrm{kg}^{-1} ; \sim 0.05-\right.$ $0.07 \%$ ) potentiometric titration (e.g., Bates et al., 1996; Dickson et al., 2007) using a VINDTA instrument (Versatile Instrument for Determination of Titration Alkalinity; manufactured by Marianda Co, Kiel, Germany). The DIC of seawater samples was determined using a standard highprecision $\left(<0.6 \mu \mathrm{mol} \mathrm{kg}{ }^{-1} ; \sim 0.05 \%\right)$ coulometric method using a VINDTA 3C system (Bates et al., 1996; Marianda Co, Germany) where a known volume of sample is acidified, converted to $\mathrm{CO}_{2}$, with evolved $\mathrm{CO}_{2}$ extracted from the seawater sample using an inert gas (i.e., ultra-highpurity nitrogen), and detected coulometrically (Dickson et al., 2007). On the ICESCAPE 2011 cruise, a small-volume $(\sim 1 \mathrm{~mL}$ sample size) DIC analyzer was used to analyze replicate DIC samples with a precision of $\sim 1-1.5 \mu \mathrm{mol} \mathrm{kg}-1$ $(\sim 0.05 \%)$, with the instrument based on non-dispersive infrared (NDIR) detection (AIRICA; Marianda Co, Germany). Both TA and DIC measurements were routinely calibrated using seawater Certified Reference Material (CRM; supplied by A. G. Dickson, Scripps Institute of Oceanography), and compared to well-characterized Sargasso Sea surface and deep water (Bates et al., 2012). Such CRM analyses provided quality assurance for these observations (Dickson et al., 2007) and ensured that the accuracy of TA and DIC compared to CRM's was within $0.1 \%\left(2 \mu \mathrm{mol} \mathrm{kg}{ }^{-1}\right)$.

\subsection{Data computations and visualization}

Seawater $\mathrm{CO}_{2}$-carbonate system parameters, including $p \mathrm{CO}_{2}(\mu \mathrm{atm}), \Omega_{\text {aragonite }}$ and $\Omega_{\text {calcite }}$ and $\mathrm{pH}$ (total scale), were computed using $\mathrm{CO} 2$ calc software (Robbins et al., 2011 ) and salinity $(S)$, temperature $(T)$, TA and DIC data. The carbonic acid dissociation constants $p K_{1}$ and $p K_{2}$ (Mehrbach et al., 1973, as refit by Dickson and Millero, 1997) were used for these computations. We estimated the calculation error range for $\Omega_{\text {aragonite }}$ and $\Omega_{\text {calcite }}$ to be \pm 0.02 (assuming a DIC and TA analytical error of $\pm 2 \mu \mathrm{mol} \mathrm{kg}{ }^{-1}$ ). The DIC/TA pair was also used to calculate $p \mathrm{CO}_{2}, \mathrm{pH}$, $\Omega_{\text {aragonite }}$ and $\Omega_{\text {calcite }}$ for the 2002-2004 SBI data reported by Bates et al (2009). A total of 2103 samples provided $p \mathrm{CO}_{2}$, $\mathrm{pH}, \Omega_{\text {aragonite }}$ and $\Omega_{\text {calcite }}$ values, with 1657 from the shelf (i.e., seafloor less than $100 \mathrm{~m}$ deep), 186 from slope waters (i.e., seafloor between $100 \mathrm{~m}$ and $200 \mathrm{~m}$ deep), and 260 from basin waters (i.e., seafloor from $200 \mathrm{~m}$ to $>3000 \mathrm{~m}$ deep). Of these, 389 were surface samples and 352 bottom-water sam- ples (i.e., closest water to the seafloor in water depths less than $200 \mathrm{~m}$ ).

Ocean Data View 4 (ODV; Schlitzer, 2011) software was used to visualize the physical and seawater $\mathrm{CO}_{2}$-carbonate chemistry data from the three cruises. Both composite scatter and contour plots of 2009-2011 data are shown in addition to cruise data from individual years. Surface data reported in the paper represented the uppermost Niskin sampler tripped at each CTD-hydrocast station, and reflect conditions in the upper part of the mixed layer $(\sim 0-10 \mathrm{~m}$ deep). The bottom-water data represent samples typically within $5 \mathrm{~m}$ of the seafloor (deepest Niskin sampler tripped at each CTD-hydrocast station) at shelf and slope stations with water depths less than $200 \mathrm{~m}$. On the western Arctic shelves, the bottom water was typically sampled at depths of $\sim 40-70 \mathrm{~m}$, although deeper samples up to $\sim 180 \mathrm{~m}$ were shown in the slope waters north of the Chukchi Sea shelf (Fig. 1). Data from the 2002-2004 Shelf-Basin Interactions project in the Chukchi Sea (e.g., Bates et al., 2005a, b; Bates, 2006) were also examined for comparison. Sea ice data were retrieved from the National Snow and Ice Data Center (Cavalieri et al., 1996, updated yearly; http://nsidc.org/data/seaice/index).

\section{Results}

\subsection{General observations from the 2009-2011 RUSALCA/ICESCAPE expeditions}

The physical and biochemical conditions of the western Arctic Ocean are strongly influenced by northward transport of Pacific Ocean water through Bering Strait (Cooper et al., 1997; Woodgate and Aagaard, 2005; Woodgate et al., 2005) and freshwater runoff from Arctic rivers onto the shelves (e.g., Anderson et al., 2011). The inflow of Pacific Ocean water $\left(\sim 1 \mathrm{~Sv}\right.$ during summer; $\left.1 \mathrm{~Sv}=10^{6} \mathrm{~m}^{3} \mathrm{~s}^{-1}\right)$ from the Bering Sea into the Chukchi Sea through Bering Strait is comprised of three different water sources associated with the Alaskan Coastal Current (ACC), Bering Sea water (BSW) and Anadyr Current (AW) waters (Fig. 1). Outflow of shelf water from the Chukchi Sea shelf predominantly occurs through submarine canyons such as Herald Valley and Barrow Canyon (Fig. 1), partly into the Canada Basin and partly eastward along the narrow Beaufort Sea shelf. There is also an episodic inflow (up to $0.1 \mathrm{~Sv}$ ) into the Chukchi Sea from the East Siberian Sea shelf through Long Strait between Wrangel Island and the Siberian coast with the Siberian Coastal Current (SCC; Weingartner, 1999). The residence time of shelf water present on the Chukchi Sea shelf is typically less than 6 months (computed from mean northward flow through Bering Strait of $1 \mathrm{~Sv}$ divided by volume of the Chukchi Sea shelf of $\sim 2.5 \times 10^{13} \mathrm{~m}^{3}$ ).

During the 2009-2011 RUSALCA/ICESCAPE expeditions, shelf water temperatures varied from -1.8 to $+7.5^{\circ} \mathrm{C}$, while salinity ranged from $\sim 24$ to 33.5 (mostly 

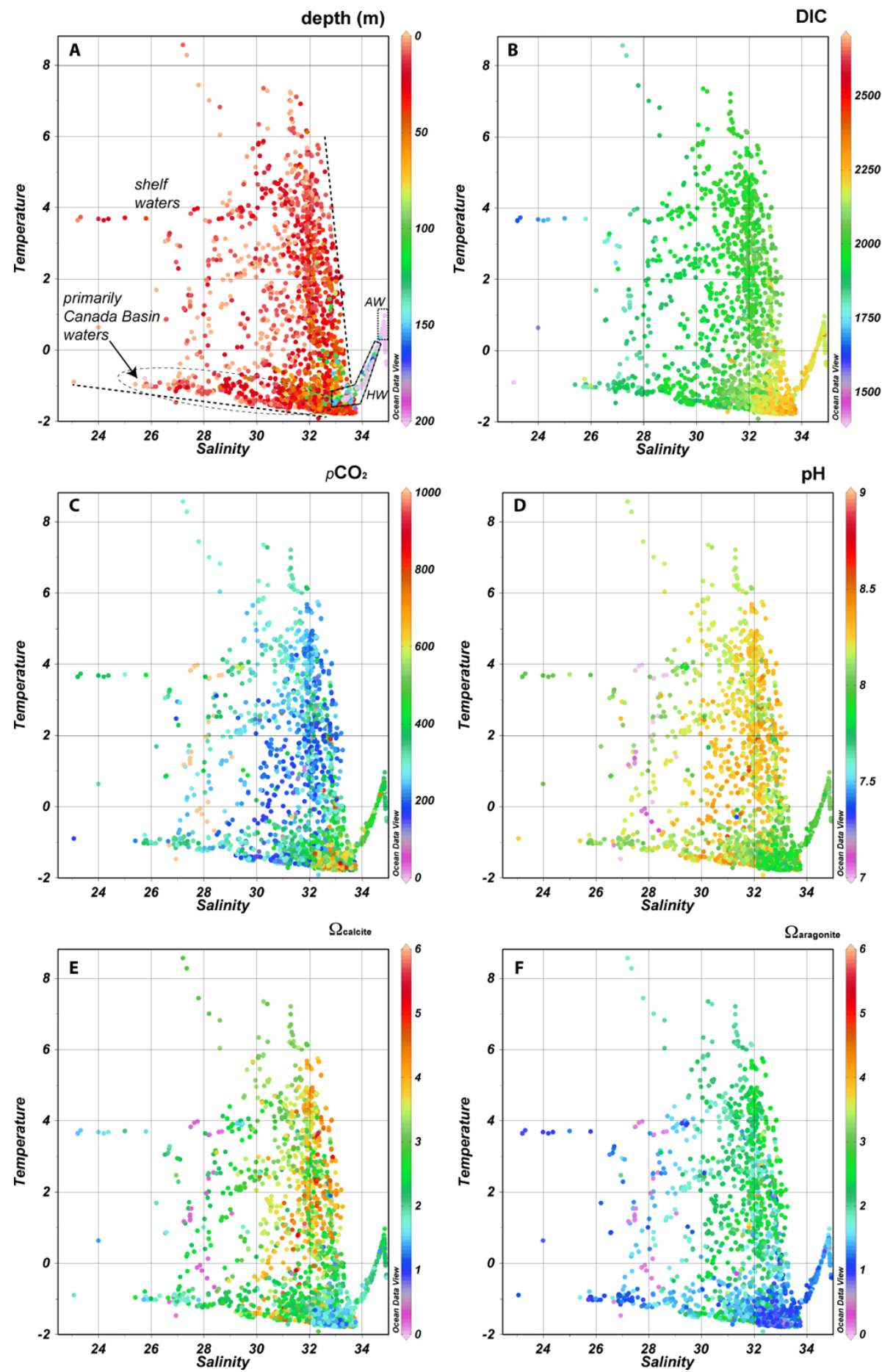

Fig. 2. Summertime scatter plots of depth and seawater $\mathrm{CO}_{2}$-carbonate chemistry superimposed on temperature versus salinity compiled for years 2009-2011 in the western Arctic Ocean. The panels include (A) depth (m) - samples within the bold dashed line represent shelf waters; samples from depths greater than $200 \mathrm{~m}$ are denoted as a uniform color (purple) and represent offshelf samples in the Canada Basin including halocline waters (HW) and Atlantic water (AW; Bates et al., 2005a). The approximate distribution of Canada Basin waters are shown within the light dashed line; (B) dissolved inorganic carbon (DIC; $\left.\mu \mathrm{mol} \mathrm{kg}{ }^{-1}\right) ;(\mathbf{C}) p \mathrm{CO}_{2}(\mu \mathrm{atm}) ;(\mathbf{D}) \mathrm{pH} ;(\mathbf{E}) \Omega_{\text {calcite }}$; and (F) $\Omega_{\text {aragonite }}$ The TS diagram shows the envelope of surface water in the western Arctic $\left(T:-1.5\right.$ to $7.5^{\circ} \mathrm{C} ; S: 24$ to 33$)$, while subsurface waters on the Chukchi Sea were more confined with regard to physical properties $\left(T:-1.5\right.$ to $\left.+1{ }^{\circ} \mathrm{C} ; S: 32-34\right)$. All panels also show the seawater $\mathrm{CO}_{2}$-carbonate chemistry properties of the Atlantic Water (AW; Emery, 2003) observed in the Canada Basin (temperature: 0.5 to $1^{\circ} \mathrm{C}$; salinity: 34.7 to 34.9 ). 


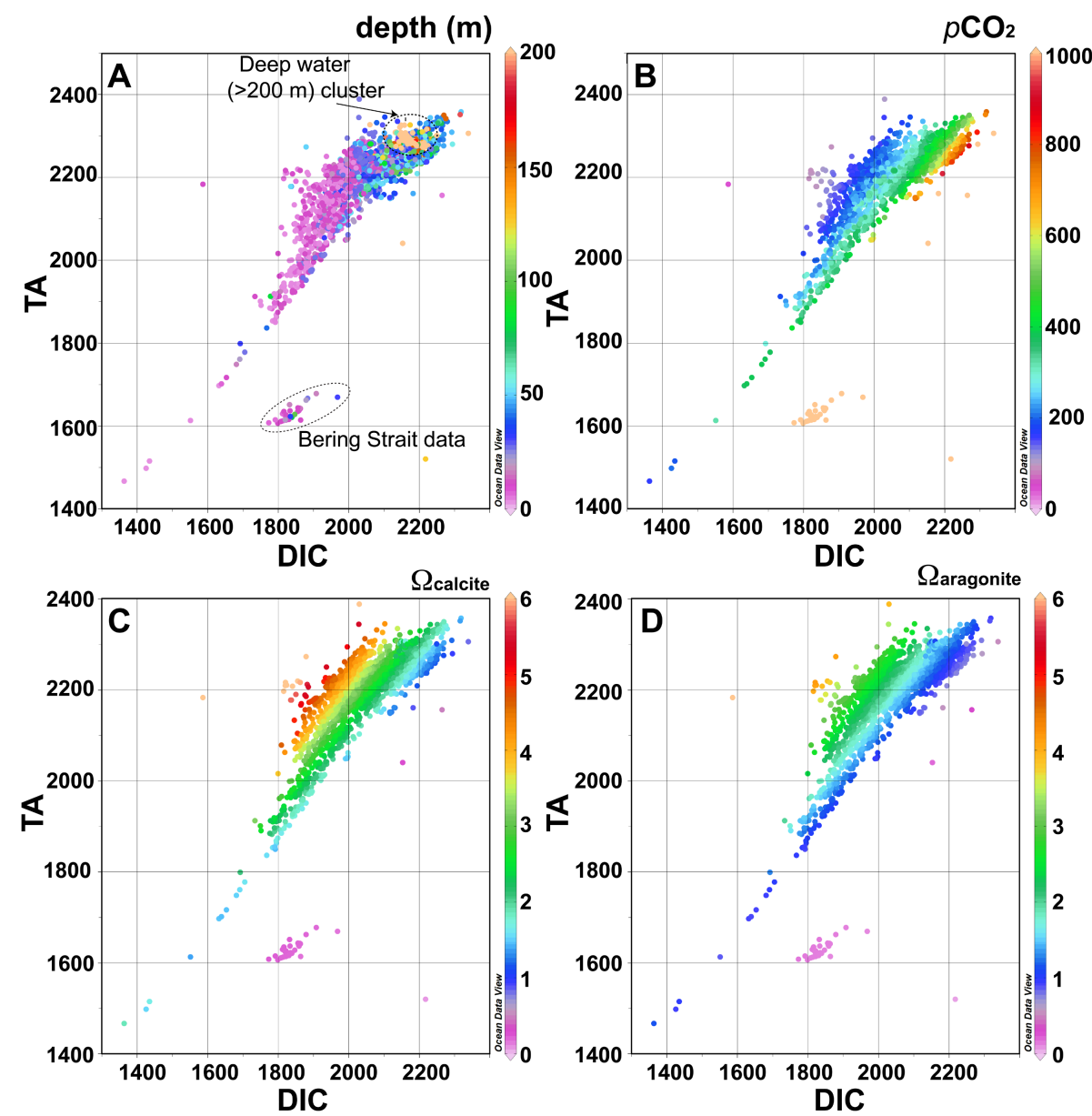

Fig. 3. Summertime scatter plots of depth, $p \mathrm{CO}_{2}, \Omega_{\text {calcite, }}$ and $\Omega_{\text {aragonite }}$ superimposed on DIC versus TA compiled for years $2009-2011$ in the western Arctic Ocean (primarily Chukchi Sea but also eastern East Siberian Sea and western Beaufort Sea). The panels include (A) depth (m) - samples from depths greater than $200 \mathrm{~m}$ are denoted as a uniform color and represent offshelf samples in the Canada Basin; (B) $p \mathrm{CO}_{2}$ ( $\mu$ atm); (D) pH; (C) $\Omega_{\text {calcite }}$; and (D) $\Omega_{\text {aragonite }}$.

from $\sim 27$ to 33; Fig. 2). Waters of the halocline and deeper layers of the Canada Basin had low temperatures $\left(\sim-1.8^{\circ} \mathrm{C}\right.$ in halocline waters to $\sim+1.8^{\circ} \mathrm{C}$ in Atlantic layer water) and were saltier than shelf waters ( $>33.5-34.5$; Fig. 2a), similar to earlier observations in the western Arctic (e.g., observations from the SBI project 2002-2004; Bates et al., 2005a; Bates, 2006).

\subsection{Seawater $\mathrm{CO}_{2}$-carbonate chemistry variability across the western Arctic}

Seawater $\mathrm{CO}_{2}$-carbonate chemistry was also highly variable across this region. Seawater TA and DIC concentrations from the three expeditions generally varied between 1400 and $2300 \mu \mathrm{mol} \mathrm{kg}^{-1}$ (Fig. 2b; DIC only shown in the paper). Surface water values typically ranged from 1850 to $2250 \mu \mathrm{mol} \mathrm{kg}-1$ for TA and 1800 to $2200 \mu \mathrm{mol} \mathrm{kg}$ for DIC with higher values across the Chukchi Sea shelf compared to the eastern East Siberian Sea, western Beaufort
Sea and offshore in the Canada Basin (Fig. 2a). The lowest TA and DIC concentrations were generally observed in Long Strait close to the coast of Siberia. These waters originate in the East Siberian Sea shelf and are carried eastward into the Chukchi Sea with the Siberian Coastal Current (Weingartner, 1999). The low TA and DIC contents of the SSC waters result from considerable freshwater input from river runoff into the East Siberian Sea shelf and sea-ice melt (Semiletov et al., 2004). Low TA and DIC concentrations were also observed on the western Beaufort Sea shelf, and likely reflect surface waters diluted with Mackenzie River freshwater outflowing onto the shelf and into the Canada Basin (Macdonald et al., 2002). Subsurface values on the shelves and in the halocline of the Canada Basin ranged between 2150 and $2300 \mu \mathrm{mol} \mathrm{kg}^{-1}$ for TA and 2050 and $2250 \mu \mathrm{mol} \mathrm{kg}-1$ for DIC (Fig. 3a). 

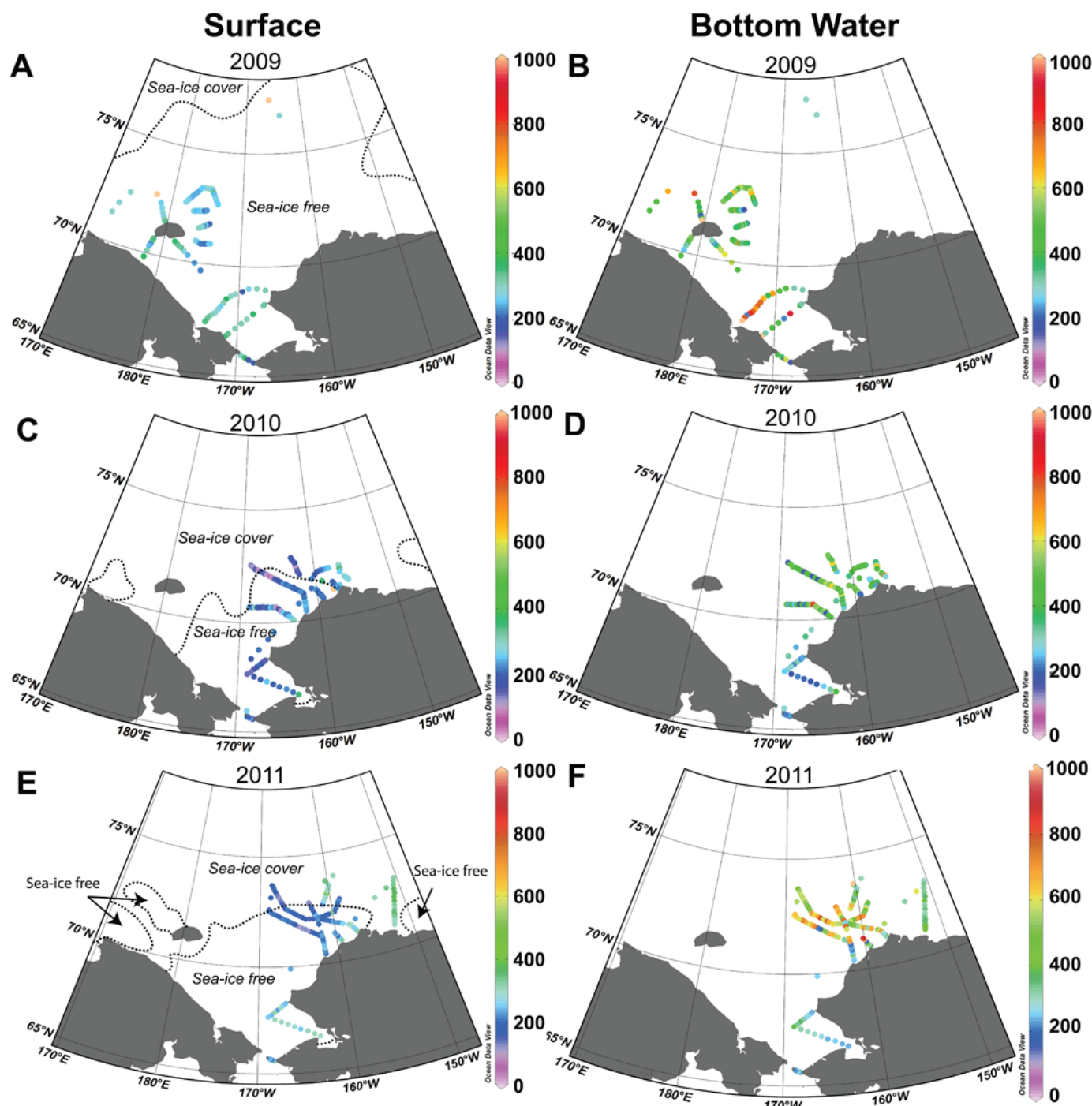

Surface

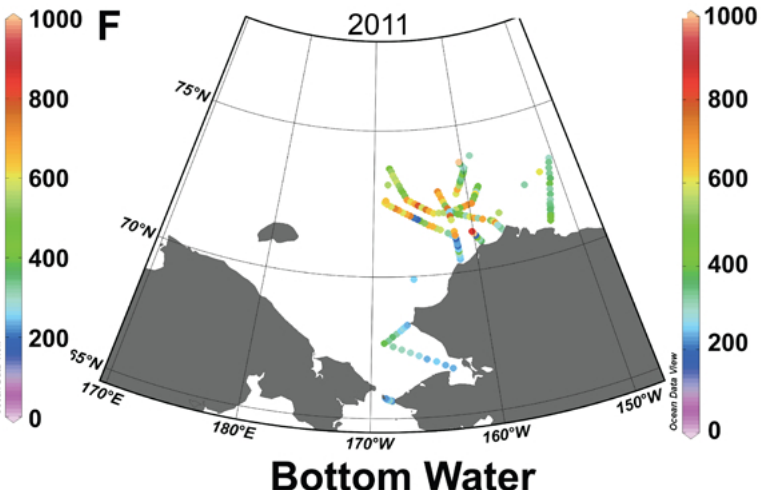

Fig. 4. Summertime surface and bottom-water maps of seawater $p \mathrm{CO}_{2}$ ( $\mu$ atm) for individual years in 2009,2010 and 2011 in the western Arctic Ocean (primarily Chukchi Sea but also eastern East Siberian Sea and western Beaufort Sea). Surface seawater $p \mathrm{CO}_{2}$ data are plotted in $(\mathbf{A}),(\mathbf{C})$ and $(\mathbf{E})$, while bottom-water seawater $p \mathrm{CO}_{2}$ data are plotted in panels $(\mathbf{B})$, (D) and (F). Sea ice data were retrieved from the National Snow and Ice Data Center (Cavalieri et al., 1996, updated yearly; http://nsidc.org/data/).

\subsection{Surface $p \mathrm{CO}_{2}$ and $\mathrm{pH}$ variability}

Seawater $p \mathrm{CO}_{2}$ and $\mathrm{pH}$ conditions across the western Arctic were highly variable, ranging from $<100$ to $>900 \mu$ atm and 7 to 8.5 , respectively (Figs. 2c, d, 3 b and 4). Surface waters had $p \mathrm{CO}_{2}$ values $(\sim 150-300 \mu \mathrm{atm})$ typically lower than atmospheric values $(\sim 390-395 \mu \mathrm{atm})$ across much of the Chukchi Sea in the period of 2009-2011 (Fig. 4a, c, e). The lowest seawater $p \mathrm{CO}_{2}$ values were observed close to Herald Valley in the westernmost Chukchi Sea in 2009 (Fig. 4a: $<200 \mu \mathrm{atm})$ and across the Chukchi Sea in 2010 and 2011 (Fig. 4 c, e: $<200 \mu \mathrm{atm})$. Even lower seawater $p \mathrm{CO}_{2}$ concentrations $(<80 \mu \mathrm{atm})$ were observed in the region of the under-sea-ice phytoplankton bloom observed in the Chukchi Sea shelf in 2010 and 2011 (Arrigo et al., 2012; Fig. 4c, e) west of Hanna Shoals (Fig. 1). These values represent some of the lowest seawater $p \mathrm{CO}_{2}$ values observed anywhere in the global ocean. Seawater $\mathrm{pH}$ ranged from 8.2 to 8.4 in most surface waters (Fig. 2d). The exceptions were waters with high $p \mathrm{CO}_{2}(>600 \mu \mathrm{atm})$ and low $\mathrm{pH}$ (7 to 7.5) observed in the East Siberian Sea north of Wrangel Island and in the Siberian Coastal Current outflowing from the East Siberian Sea into the Chukchi Sea through Long Strait in 2009 (Figs. 2c, d and 3b). Similarly high $p \mathrm{CO}_{2}$ has been observed in the Siberian Coastal Current previously (Fransson et al., 2009). This finding is not surprising given the 

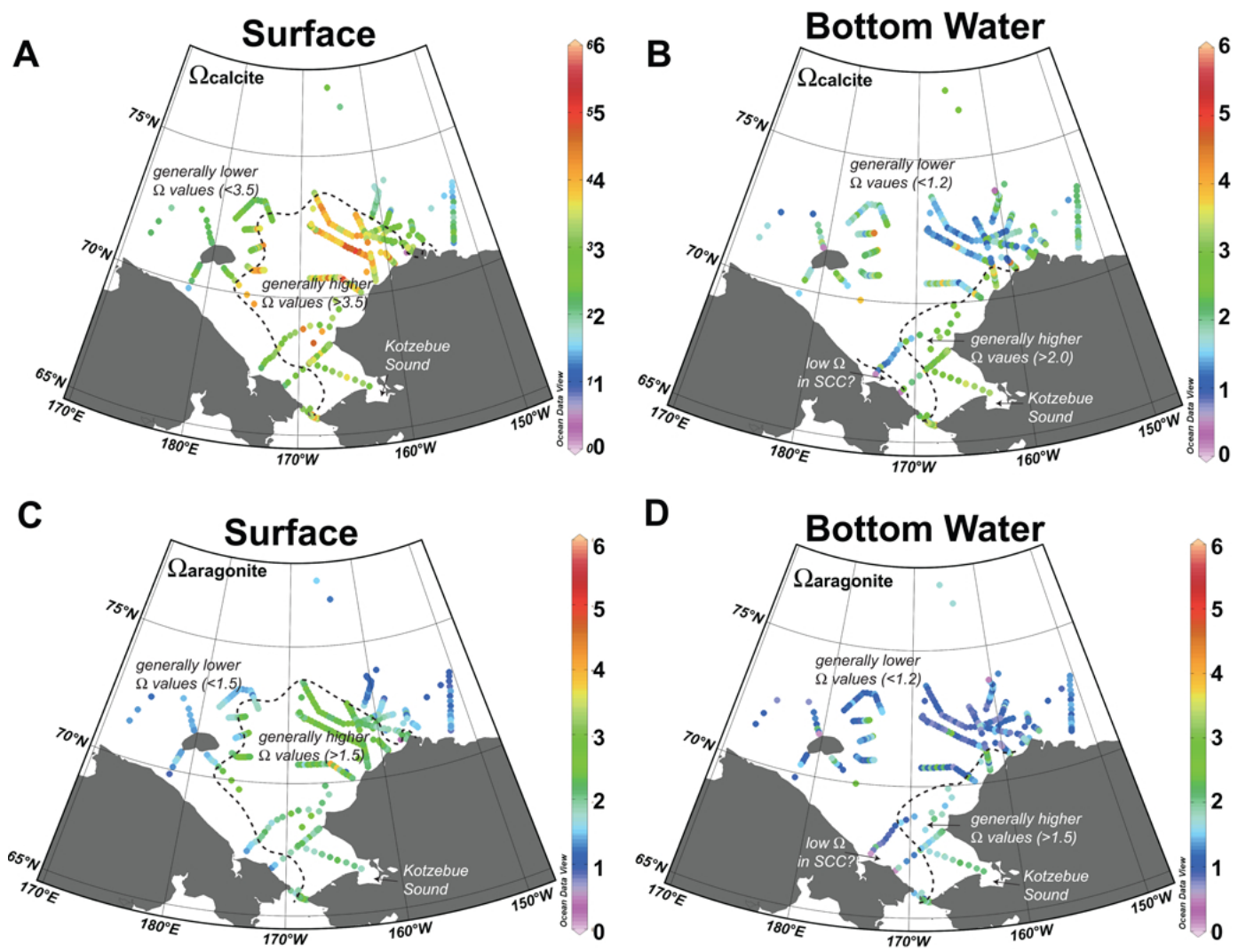

Fig. 5. Composite (2009-2011) summertime maps of surface and bottom-water $\Omega_{\text {calcite }}$ and $\Omega_{\text {aragonite }}$ in the western Arctic Ocean (primarily Chukchi Sea but also eastern East Siberian Sea and western Beaufort Sea). The panels include (A) surface $\Omega_{\text {calcite }} ;\left(\right.$ B) bottom-water $\Omega_{\text {calcite }}$; (C) surface $\Omega_{\text {aragonite }}$; and (D) bottom-water $\Omega_{\text {aragonite }}$.

high seawater $p \mathrm{CO}_{2}$ values $(\sim 500$ to $\sim 1500 \mu$ atm) previously observed in the near-shore bays and estuaries of the East Siberian Sea (e.g., Tiksi Bay) and Kolyma River outflow (Semiletov et al., 1999, 2007; Pipko et al., 2011).

\subsection{Subsurface $p \mathrm{CO}_{2}$ and $\mathrm{pH}$ variability}

Subsurface seawater $p \mathrm{CO}_{2}$ had higher values $(\sim 350->900)$ and low $\mathrm{pH}$ values $(\sim 7.3-7.8)$ when compared to surface waters (Figs. 2c, d, $3 b$, and $4 b, d, f$ ). Seawater $\mathrm{CO}_{2}$-carbonate chemistry differences between surface and bottom waters were as much as $600-800 \mu \mathrm{atm}$ for seawater $p \mathrm{CO}_{2}$ and 1 to 1.5 for $\mathrm{pH}$, respectively. This reflects strong physical stratification between the surface mixed-layer and subsurface waters. High seawater $p \mathrm{CO}_{2}$ values greater than $400 \mu \mathrm{atm}$ were observed in bottom waters close to the seafloor across the southern Chukchi Sea and East Siberian Sea in 2009 (Fig. 4b), and in the northern Chukchi Sea in 2010 and 2011 (Fig. 4d, f). Interestingly, low subsurface $p \mathrm{CO}_{2}$ values $(\sim 250-350 \mu \mathrm{atm})$ were observed at Bering Strait and southern Chukchi Sea shelf, presumably reflecting inflow of low- $p \mathrm{CO}_{2}$ water from the Bering Sea shelf (Bates et al., 2011a).

\subsection{Saturation states of $\boldsymbol{\Omega}_{\text {aragonite }}$ and $\boldsymbol{\Omega}_{\text {calcite }}$}

The saturation states of $\Omega_{\text {calcite }}$ and $\Omega_{\text {aragonite }}$ are useful indicators of the status of ocean acidification on the western Arctic shelves. The $\Omega$ values were highly variable with $\Omega_{\text {calcite }}$ and $\Omega_{\text {aragonite }}$ ranging from $<0.5$ to 5.5 and $<0.5$ to 4 , respectively (Figs. $2 \mathrm{e}, \mathrm{f}$ and $3 \mathrm{c}, \mathrm{d}$ ). In surface waters across the western Arctic, $\Omega_{\text {calcite }}$ and $\Omega_{\text {aragonite }}$ values were typically greater than 1 (Fig. 5a, c). Across much of the Chukchi Sea shelf, $\Omega_{\text {calcite }}$ and $\Omega_{\text {aragonite }}$ values ranged from 3.5 to 5 and 2 to 3, respectively (Fig. 5), with surface waters highly oversaturated with respect to $\mathrm{CaCO}_{3}$ minerals. Elsewhere, $\Omega_{\text {calcite }}$ and $\Omega_{\text {aragonite }}$ values were lower in the westernmost Chukchi Sea and eastern East Siberian Sea shelves, ranging from 2 to 3 and 1.5 to 2, respectively (Fig. 5), with lower values in Long Strait. The low $\Omega_{\text {calcite }}$ and $\Omega_{\text {aragonite }}$ values observed in the East Siberian Sea shelf were not unexpected (Anderson et al., 2010, 2011) given that ESS surface waters have high seawater $p \mathrm{CO}_{2}$ (and low $\mathrm{pH}$ ) values. The high seawater $p \mathrm{CO}_{2}$ of surface waters (and low $\mathrm{pH}$ and $\Omega$ values) have been attributed primarily to the remineralization of terrestrial organic matter (introduced to the ESS from Siberian rivers; e.g., Anderson et al., 1990, 2009; Cauwet and Sidorov, 


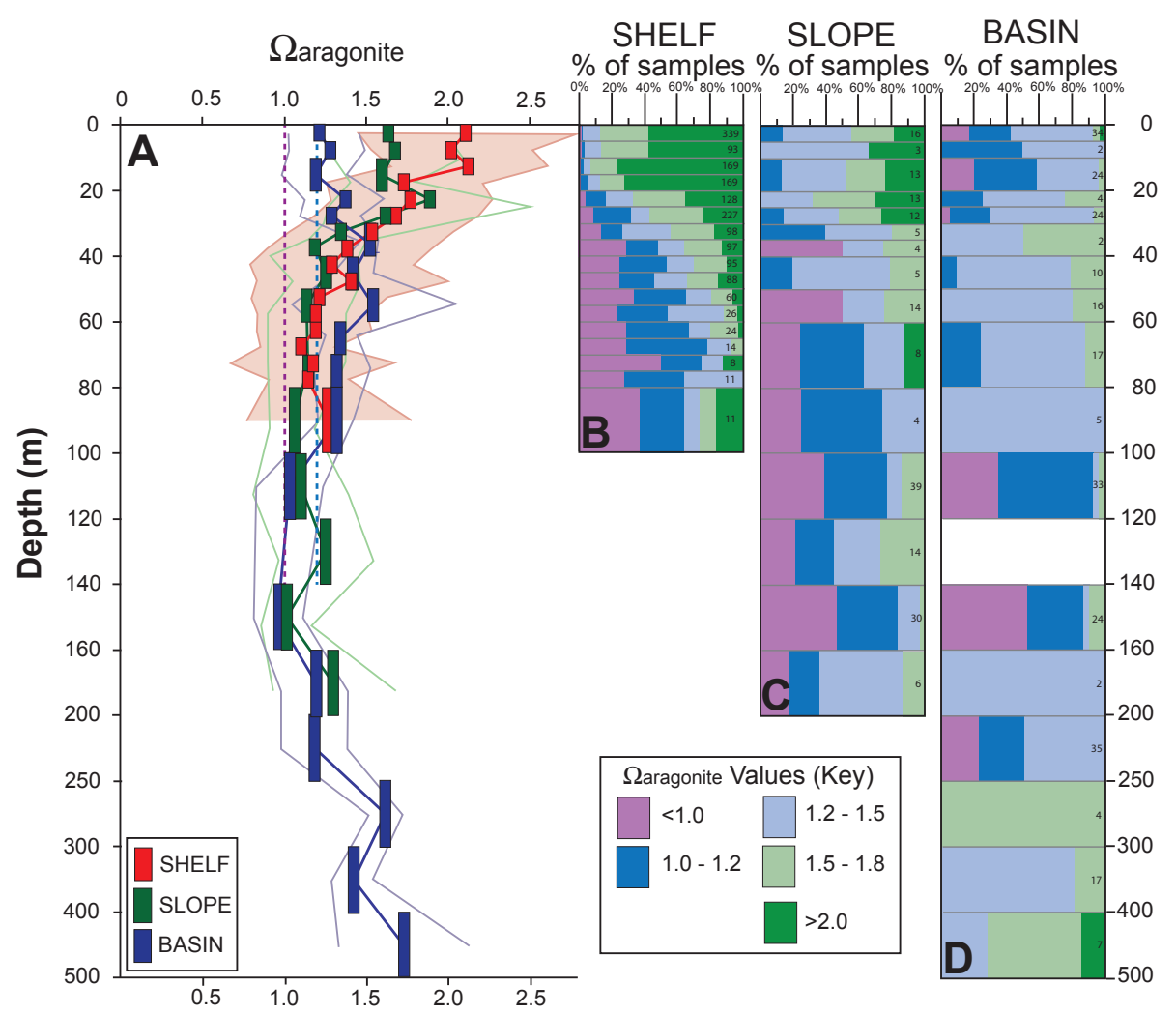

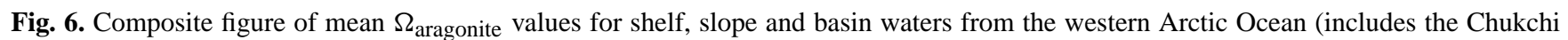
Sea, eastern East Siberian Sea, western Beaufort Sea shelf and Canada Basin) as observed during the 2009-2011 RUSALCA/ICESCAPE

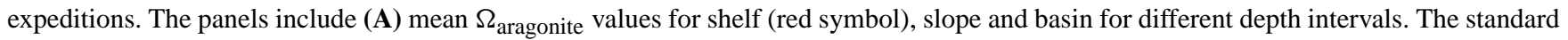
deviation of mean shelf $\Omega_{\text {aragonite }}$ at each depth interval is shown in light red, and gives some indication of range of $\Omega$ values. The standard deviation of $\Omega$ values is also shown for slope (green lines) and basin (blue lines) waters. The vertical height of each mean $\Omega_{\text {aragonite value }}$ shows the depth interval (i.e., $0-5 \mathrm{~m}$ for uppermost depth interval); (B) the $\%$ of sampled water within the defined $\Omega$ ranges (i.e., $<1.0$ is shown as purple; 1.0-1.2 as deep blue, 1.2-1.5 light blue, 1.5-2.0 as light green, and > 2.0 as dark green); (C) as in panel B but for slope waters; and (D) as in (B) but for basin waters. As in (B), $\Omega$ values in (C) and (D) are differentiated by color (i.e., $<1.0$ is shown as purple; 1.0-1.2 as deep blue, 1.2-1.5 light blue, 1.5-2.0 as light green, and > 2.0 as dark green). In (B), (C), and (D), the number of samples (i.e., $n$ of sample within the depth horizon) that comprise each binned depth horizon is given in the right-hand corner of each depth bin, replicating $n$ values given in Table 1.

1996; Kattner et al., 1999), and marine-derived organic carbon back to $\mathrm{CO}_{2}$.

\subsubsection{Surface waters}

In Fig. 6, we show the variability of $\Omega_{\text {aragonite }}$ against depth for shelf and slope waters (i.e., bottom depth from 100 to $200 \mathrm{~m}$ ) of the Chukchi Sea, but also compared to waters sampled in the Canada Basin. For shelf waters, the mean $\Omega_{\text {aragonite }}$ of surface waters (i.e., $0-15 \mathrm{~m}$ ) was $\sim 2.1 \pm 0.6$, decreasing with depth to $<1.2$ below $\sim 40 \mathrm{~m}$ deep (Fig. 6a). Although not shown, a similar profile of $\Omega_{\text {calcite }}$ exhibits a similar vertical profile with values $\sim 0.6-0.8$ higher. The range of surface $\Omega_{\text {aragonite }}$ values was large, reflecting variability of $\Omega_{\text {aragonite }}$ and $\Omega_{\text {calcite }}$ across the region (Fig. 7). For example, relatively high surface $\Omega_{\text {aragonite }}$ values $(>2)$ were evident in the central Chukchi Sea compared to the west- ern Chukchi Sea and East Siberian Sea (Fig. 7c). More than $60 \%$ of shelf surface samples had $\Omega_{\text {aragonite values of }}>2$ (Fig. 6b). In the slope regions (i.e., $100-200 \mathrm{~m}$ water depth) of the Chukchi Sea shelf, the mean surface $\Omega_{\text {aragonite was }}$ lower than shelf waters at $\sim 1.6 \pm 0.4$, but these waters also exhibit a decrease in $\Omega_{\text {aragonite }}$ with depth to $<1.2$ (Fig. 6a). Compared to shelf waters, only $\sim 20 \%$ of slope water samples had $\Omega_{\text {aragonite }}$ values of $>2$, while there was a greater

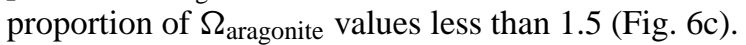

In contrast to the surface and slope waters of the Chukchi, East Siberian and western Beaufort shelves, surface/mixedlayer water $\Omega$ values in the Canada Basin were close to 1 to 1.5 for calcite and even below 1 for aragonite. The mean $\Omega_{\text {aragonite }}$ of surface waters (i.e., $0-20 \mathrm{~m}$ ) was $\sim 1.2 \pm 0.2$ (Fig. 6a). Nearly $50 \%$ of polar mixed-layer waters sampled had $\Omega_{\text {aragonite }}$ values less than 1.2 , and $\sim 20 \%$ below 1 (Fig. 6d). Unlike shelf and slope waters, $\Omega_{\text {aragonite }}$ 


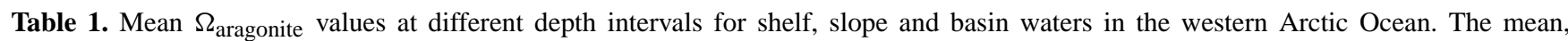
standard deviation and number of samples (bracketed) are given for summertime cruises in 2002 (SBI), 2004 (SBI) and 2009-2011 (RUSALCA/ICESCAPE). The last column denotes the difference between 2009-2011 data and earlier SBI $\Omega_{\text {aragonite }}$ data. We note "similar" if the mean of the $2009-2011 \Omega_{\text {aragonite }}$ data is within $10 \%$ of one or more earlier years. ${ }^{*}$ denotes this depth interval incorporated into mean value above.

\begin{tabular}{|c|c|c|c|c|}
\hline Depth interval & $\begin{array}{l}2002 \\
\text { Mean } \Omega_{\text {aragonite }} \\
\text { std dev and }(n)\end{array}$ & $\begin{array}{l}2004 \\
\text { Mean } \Omega \text { aragonite } \\
\text { std dev and }(n)\end{array}$ & $\begin{array}{l}2009-2011 \\
\text { Mean } \Omega_{\text {aragonite }} \\
\text { std dev and }(n)\end{array}$ & $\begin{array}{l}\Delta \Omega_{\text {aragonite }} \\
\text { difference }\end{array}$ \\
\hline SHELF & 2002 & 2004 & 2009-2011 & \\
\hline $0-5 \mathrm{~m}$ & $2.01 \pm 0.74(22)$ & $1.99 \pm 0.56(16)$ & $2.11 \pm 0.67(339)$ & similar \\
\hline $5-10 \mathrm{~m}$ & $2.17 \pm 0.62(9)$ & $2.28 \pm 0.62(14)$ & $2.02 \pm 0.50(93)$ & similar \\
\hline $10-15 \mathrm{~m}$ & $2.15 \pm 0.41(13)$ & $2.27 \pm 0.64(6)$ & $2.13 \pm 0.47(169)$ & similar \\
\hline $15-20 \mathrm{~m}$ & $2.20 \pm 0.55(11)$ & $2.16 \pm 0.53(6)$ & $1.73 \pm 0.46(169)$ & $(-)$ lower \\
\hline $20-25 \mathrm{~m}$ & $1.89 \pm 0.45(15)$ & $1.99 \pm 0.46(6)$ & $1.77 \pm 0.50(129)$ & (-) lower \\
\hline $25-30 \mathrm{~m}$ & $1.66 \pm 0.47(6)$ & $1.80 \pm 0.37(3)$ & $1.68 \pm 0.51(227)$ & similar \\
\hline $30-35 \mathrm{~m}$ & $1.88 \pm 0.56(10)$ & $1.77 \pm 0.41(5)$ & $1.53 \pm 0.48(98)$ & (-) lower \\
\hline $35-40 \mathrm{~m}$ & $1.72 \pm 0.27(3)$ & $1.92 \pm 0.11(3)$ & $1.37 \pm 0.57(97)$ & $(-)$ lower \\
\hline $40-45 \mathrm{~m}$ & $1.65 \pm 0.51(9)$ & $1.32 \pm 0.72(3)(40-50 \mathrm{~m})$ & $1.33 \pm 0.43(95)$ & similar \\
\hline $45-50 \mathrm{~m}$ & $1.42 \pm 0.20(2)$ & $*$ & $1.41 \pm 0.57(88)$ & similar \\
\hline $50-55 \mathrm{~m}$ & $1.29 \pm 0.35(5)(50-60 \mathrm{~m})$ & $1.62 \pm 0.47(2)(50-60 \mathrm{~m})$ & $1.21 \pm 0.43(60)$ & similar \\
\hline $55-60 \mathrm{~m}$ & $*$ & $*$ & $1.18 \pm 0.36(26)$ & \\
\hline $60-65 \mathrm{~m}$ & $1.20 \pm 0.31(5)$ & $1.36 \pm 0.14(2)(60-70 \mathrm{~m})$ & $1.19 \pm 0.37(24)$ & similar \\
\hline $65-70 \mathrm{~m}$ & $1.25 \pm 0.40(3)$ & $*$ & $1.10 \pm 0.24(14)$ & $(-)$ lower \\
\hline $70-75 \mathrm{~m}$ & $1.38 \pm 0.18(3)$ & $1.43 \pm 0.50(2)(70-80 \mathrm{~m})$ & $1.17 \pm 0.52(8)$ & $(-)$ lower \\
\hline $75-80 \mathrm{~m}$ & $1.11 \pm 0.19(3)$ & $*$ & $1.16 \pm 0.25(11)$ & similar \\
\hline $80-100 \mathrm{~m}$ & $1.21 \pm 0.19$ & $1.57 \pm 0.01(2)$ & $1.26 \pm 0.51(11)$ & similar \\
\hline SLOPE & 2002 & 2004 & 2009-2011 & \\
\hline $0-5 \mathrm{~m}$ & $1.48 \pm 0.63(11)(0-10 \mathrm{~m})$ & $1.90 \pm 0.37(16)$ & $1.63 \pm 0.38(16)$ & ?variable \\
\hline $5-10 \mathrm{~m}$ & $*$ & $2.56 \pm 0.93(7)$ & $1.67 \pm 0.42(3)$ & $(-)$ lower \\
\hline $10-15 \mathrm{~m}$ & $1.94 \pm 0.41(13)(10-20 \mathrm{~m})$ & $2.22 \pm 0.75(7)(10-20 \mathrm{~m})$ & $1.58 \pm 0.39(13)(10-20 \mathrm{~m})$ & $(-)$ lower \\
\hline $15-20 \mathrm{~m}$ & $*$ & $*$ & $*$ & \\
\hline $20-25 \mathrm{~m}$ & $1.99 \pm 0.45(6)(20-30 \mathrm{~m})$ & $1.67 \pm 0.22(4)(20-30 \mathrm{~m})$ & $1.89 \pm 0.65(13)$ & similar \\
\hline $25-30 \mathrm{~m}$ & $*$ & $*$ & $1.63 \pm 0.36(12)$ & \\
\hline $30-35 \mathrm{~m}$ & $1.69 \pm 0.16(4)(30-40 \mathrm{~m})$ & $1.68 \pm 0.25(4)(30-40 \mathrm{~m})$ & $1.35 \pm 0.18(5)$ & (-) lower \\
\hline $35-40 \mathrm{~m}$ & $*$ & $*$ & $1.19 \pm 0.27(4)$ & \\
\hline $40-50 \mathrm{~m}$ & $1.48 \pm 0.20(5)$ & $1.68 \pm 0.36(2)$ & $1.25 \pm 0.25(5)$ & $(-)$ lower \\
\hline $50-60 \mathrm{~m}$ & $1.58 \pm 0.19(3)$ & $\mathrm{n} / \mathrm{a}$ & $1.15 \pm 026(14)$ & (-) lower \\
\hline $60-70 \mathrm{~m}$ & $1.30 \pm 0.09(6)$ & $1.57 \pm 0.40(3)$ & $\mathrm{n} / \mathrm{a}$ & \\
\hline $70-80 \mathrm{~m}$ & $1.38 \pm 0.18(3)$ & $1.29 \pm 0.14(3)$ & $1.15 \pm 024(8)$ & $(-)$ lower \\
\hline $80-100 \mathrm{~m}$ & $1.22 \pm 0.21(5)$ & $1.18 \pm 0.01(2)$ & $1.07 \pm 0.15(4)$ & similar \\
\hline $100-120 \mathrm{~m}$ & $1.14 \pm 0.15(6)$ & $1.26 \pm 0.33(4)$ & $1.11 \pm 0.31(39)$ & similar \\
\hline $120-140 \mathrm{~m}$ & $1.16 \pm 0.21(4)$ & $1.29 \pm 0.05(2)$ & $1.25 \pm 0.32(14)$ & similar \\
\hline $140-160 \mathrm{~m}$ & $1.29 \pm 0.25(9)$ & $1.14 \pm 0.05(2)$ & $1.02 \pm 0.16(30)$ & similar \\
\hline $160-200 \mathrm{~m}$ & $1.25 \pm 0.30(6)$ & $1.47 \pm 0.07(2)$ & $1.29 \pm 0.38(6)$ & similar \\
\hline BASIN & 2002 & 2004 & 2009-2011 & \\
\hline $0-5 \mathrm{~m}$ & $1.43 \pm 0.43(6)(0-10 \mathrm{~m})$ & $1.68 \pm 0.28(8)$ & $1.21 \pm 0.31(34)$ & $(-)$ lower \\
\hline $5-10 \mathrm{~m}$ & $*$ & $1.62 \pm 0.33(5)$ & $1.28 \pm 0.23(2)$ & $(-)$ lower \\
\hline $10-15 \mathrm{~m}$ & $1.87 \pm 0.37(3)(10-20 \mathrm{~m})$ & $1.74 \pm 0.26(6)(10-20 \mathrm{~m})$ & $1.18 \pm 0.21(24)(10-20 \mathrm{~m})$ & $(-)$ lower \\
\hline $15-20 \mathrm{~m}$ & $*$ & $*$ & $*$ & \\
\hline $20-25 \mathrm{~m}$ & $1.87 \pm 0.17(2)(20-30 \mathrm{~m})$ & $1.84 \pm 0.13(6)(20-30 \mathrm{~m})$ & $1.38 \pm 0.25(4)(20-30 \mathrm{~m})$ & (-) lower \\
\hline $25-30 \mathrm{~m}$ & $*$ & $*$ & $1.29 \pm 0.20(24)$ & \\
\hline $30-35 \mathrm{~m}$ & $\mathrm{n} / \mathrm{a}$ & $1.68 \pm 0.25(5)(30-40 \mathrm{~m})$ & $1.51 \pm 0.04(2)(30-40 \mathrm{~m})$ & (-) lower \\
\hline $35-40 \mathrm{~m}$ & $\mathrm{n} / \mathrm{a}$ & $*$ & $*$ & \\
\hline $40-50 \mathrm{~m}$ & $1.93 \pm 0.53(2)$ & $1.70 \pm 0.43(5)$ & $1.40 \pm 0.16(10)$ & (-) lower \\
\hline $50-60 \mathrm{~m}$ & $1.44(1)$ & $\mathrm{n} / \mathrm{a}$ & $1.53 \pm 0.53(16)$ & similar \\
\hline
\end{tabular}


Table 1. Continued.

\begin{tabular}{lllll}
\hline Depth interval & $\begin{array}{l}2002 \\
\text { Mean } \Omega_{\text {aragonite }} \\
\text { std dev and }(n)\end{array}$ & $\begin{array}{l}2004 \\
\text { Mean } \Omega \text { aragonite } \\
\text { std dev and }(n)\end{array}$ & $\begin{array}{l}2009-2011 \\
\text { Mean } \Omega_{\text {aragonite }} \\
\text { std dev and }(n)\end{array}$ & $\begin{array}{l}\Delta \Omega_{\text {aragonite }} \\
\text { difference }\end{array}$ \\
\hline $60-70 \mathrm{~m}$ & $1.08 \pm 0.01(2)(60-100 \mathrm{~m})$ & $\begin{array}{l}1.30 \pm 0.72(2)(60-80 \mathrm{~m}) \\
*\end{array}$ & $\begin{array}{l}1.34 \pm 0.09(17) \\
*\end{array}$ & $\begin{array}{l}\text { similar } \\
7\end{array}$ \\
$80-100 \mathrm{~m}$ & $*$ & $1.26 \pm 0.37(5)$ & $1.31 \pm 0.08(5)$ & similar \\
$100-120 \mathrm{~m}$ & $1.03 \pm 0.12(2)(120-140 \mathrm{~m})$ & $1.45 \pm 0.24(4)(120-140 \mathrm{~m})$ & $1.06 \pm 0.32(33)$ & similar \\
$120-140 \mathrm{~m}$ & $*$ & $*$ & $\mathrm{n} / \mathrm{a}$ & \\
$140-160 \mathrm{~m}$ & $1.15 \pm 0.12(2)$ & $1.27 \pm 0.24(5)(140-200 \mathrm{~m})$ & $0.97 \pm 0.14(24)$ & $(-)$ lower \\
$160-200 \mathrm{~m}$ & $1.35(1)$ & $*$ & $1.19 \pm 0.21(2)$ & similar \\
$200-250 \mathrm{~m}$ & $1.46 \pm 0.11(6)$ & $\mathrm{n} / \mathrm{a}$ & $1.18 \pm 0.21(35)$ & $(-)$ lower \\
$250-300 \mathrm{~m}$ & $1.57 \pm 0.06(5)$ & $\mathrm{n} / \mathrm{a}$ & $1.62 \pm 0.11(4)$ & similar \\
$300-350 \mathrm{~m}$ & $1.66 \pm 0.06(3)$ & $\mathrm{n} / \mathrm{a}$ & $1.41 \pm 0.13(17)$ & $(-)$ lower \\
$350-400 \mathrm{~m}$ & $1.69 \pm 0.11(4)$ & $\mathrm{n} / \mathrm{a}$ & $1.74 \pm 0.40(7)$ & similar \\
\hline
\end{tabular}

values in the Canada Basin increased with depth, and halocline layer waters had $\Omega_{\text {aragonite }}$ of $>1.5$ at depths of $\sim 40$ $100 \mathrm{~m}$ deep). Such low surface saturation states, especially for aragonite, observed from 2009 to 2011, confirm previous findings of low $\Omega$ in summertime polar mixed-layer waters of the Canada Basin (Jütterstrom and Anderson, 2010), which were ascribed to contributions of high- $p \mathrm{CO}_{2}$ and low$\mathrm{pH} / \Omega$ sea-ice melt waters and freshwaters from the Mackenzie River.

\subsubsection{Subsurface waters}

The saturation states of calcite and aragonite in subsurface waters on the western Arctic shelves were much lower than surface water values (Figs. 6a and 7). Across much of the Chukchi Sea shelf, $\Omega_{\text {calcite }}$ and $\Omega_{\text {aragonite }}$ values ranged from 1 to 1.5 and $<1$ to 2 , respectively (Figs. 5 b, d and 7 ). In many regions of the Chukchi Sea and East Siberian Sea, subsurface water had $\Omega_{\text {calcite }}$ values that were close to values of

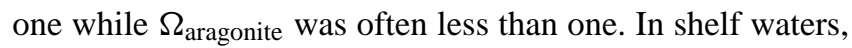
$>50-60 \%$ of subsurface waters sampled deeper than $40 \mathrm{~m}$ had values of less than 1.2 ( $\sim 30 \%$ less than 1; Fig. $6 b)$. Subsurface waters of the East Siberian Sea shelf had low $\Omega_{\text {aragonite values (i.e., less than 1.2), and this is likely due to }}$ remineralization of organic carbon back to $\mathrm{CO}_{2}$ (Semiletov et al., 2007; Anderson et al., 2010). Similarly, in the northern Chukchi Sea shelf, the low $\Omega$ values were co-located in those areas coincident with high rates of euphotic zone marine phytoplankton primary production and thus likely reflect subsurface remineralization of vertically exported organic carbon (Fig. 6). However, there were locations on the Chukchi Sea shelf (particularly in the SW Chukchi Sea) where subsurface waters had $\Omega_{\text {aragonite of }}>2$ (Figs. $6 \mathrm{~b}$, c and 7; $20 \%$ of samples $>1.5$ ), presumably reflecting input of low- $p \mathrm{CO}_{2}$ and high-pH/ $\Omega$ waters inflowing from the Bering Sea shelf. Surface waters of the Alaskan Coastal Current that flows north- wards through the eastern section of Bering Strait had values of $>3$ during summertime of 2009 to 2011 .

In the Canada Basin, adjacent to the Chukchi Sea, low $\Omega_{\text {aragonite values of }<1.2(\sim 80 \% \text { of samples; Fig. } 6 \mathrm{~d}) \text { were }}$ observed in lower halocline waters at $\sim 100$ to $250 \mathrm{~m}$ deep. Such low $\Omega_{\text {aragonite values were observed during the SBI }}$ 2002-2004 expeditions (Bates et al., 2009), and earlier during the 1990s (Jutterström and Anderson, 2005), suggesting that this feature has persistence over the recent past.

\subsubsection{Shelf and slope bottom waters}

During the RUSALCA/ICESCAPE 2009 to 2011 expeditions, $>300$ samples of shelf and slope bottom water nearest the seafloor were collected. The $\Omega_{\text {aragonite values for bot- }}$ tom water (Fig. 8) exhibited a similar vertical profile to that as shown for shelf waters in Fig. 6a. Shallow bottom waters had $\Omega_{\text {aragonite of }}>1.5$ (in SE Chukchi Sea and Kotzebue Sound), while nearly $70 \%$ of bottom-water samples deeper than $20 \mathrm{~m}$ had $\Omega_{\text {aragonite }}$ of $<1.2$ (mostly East Siberian Sea and the majority of Chukchi Sea). Of these, $40 \%$ of samples had $\Omega_{\text {aragonite }}$ of $<1.0$ (Fig. 8). These data suggest that the shallow benthos $(<20 \mathrm{~m}$ deep) and areas strongly influenced by the Alaskan Coastal Current (i.e., shallow Kotzebue Sound; Fig. 1) have relatively high $\Omega$ values $(>1.5)$, whereas elsewhere the deeper seafloor benthos is exposed to summertime undersaturation for aragonite. A caveat for interpreting potential area of the Chukchi Sea from Figs. 6 and 8 is that they represent $\%$ samples with proscribed $\Omega$ values and thus do not reflect a realistic areal estimate due to spatio-temporal variability. However, Fig. 5 is shown with approximate areas of relatively high $(\Omega>1.2$ ) or low (i.e., $\Omega<1.2$ ) $\Omega$ values. 


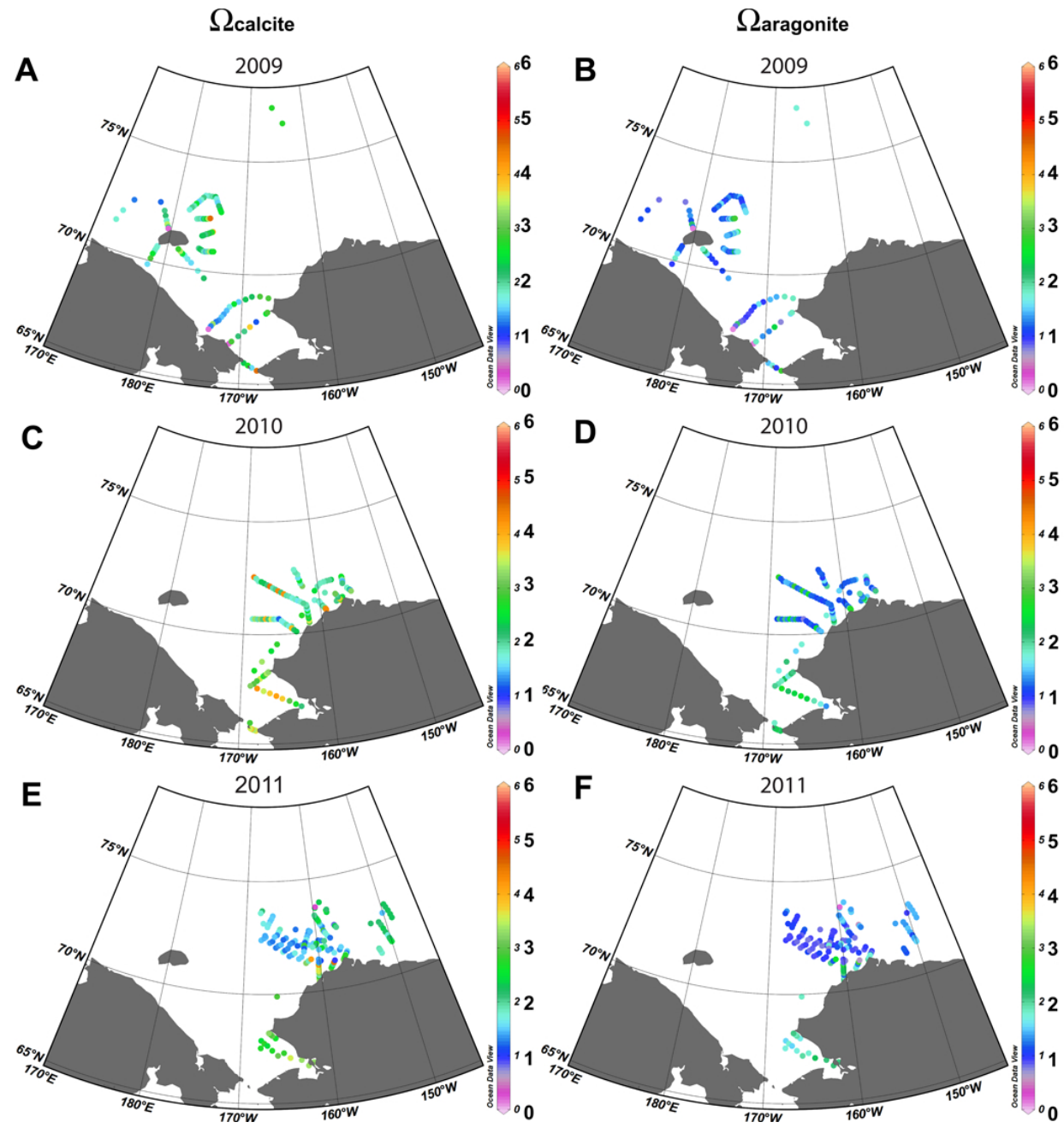

Fig. 7. Summertime maps of bottom-water $\Omega_{\text {calcite }}$ and $\Omega_{\text {aragonite }}$ for individual years in 2009, 2010 and 2011 in the western Arctic Ocean (primarily Chukchi Sea but also eastern East Siberian Sea and western Beaufort Sea). $\Omega_{\text {calcite }}$ data are plotted in panels (A), (C) and (E), while $\Omega_{\text {aragonite }}$ data are plotted in $(\mathbf{B}),(\mathbf{D})$ and $(\mathbf{F})$.

\section{Discussion}

\subsection{Is there any change over time in the $\Omega$ of surface and subsurface waters in the western Arctic?}

The 2009 to 2011 RUSALCA/ICESCAPE data revealed that a substantial percentage of shelf waters sampled had values of $\Omega_{\text {aragonite }}$ less than 1 (Fig. 6) during the sea-ice-free summertime period. Nearly $70 \%$ of bottom water had $\Omega_{\text {aragonite values of less than } 1.2 \text { and } \sim 40 \% \text { less than } 1}$ (Fig. 8). Previous observations in the period 2002-2004 showed undersaturated bottom waters present on the northern slope of the Chukchi Sea (Bates et al., 2009) rather than on the entire shelf as observed more recently. In 2002, 11\% and $\sim 3 \%$ of slope waters had $\Omega_{\text {aragonite values lower than } 1}$ sampled at 0-50 m and 50-100 m, respectively. In 2004, the $\%$ of slope waters sampled with $\Omega_{\text {aragonite }}$ values lower than 1 increased to $\sim 19 \%$ and $\sim 14 \%$, respectively, for the $0-50 \mathrm{~m}$ and $50-100 \mathrm{~m}$ depths.

The comparison between SBI and RUSALCA/ICESCAPE data suggests that the occurrence of low- $\Omega_{\text {aragonite }}$ water has increased on the western Arctic shelf over the last decade. The caveat is that these data represent repeat summertime observations over just a few years and thereby cannot represent time-series sampling. It should also be noted that the 2002-2004 SBI sampled data primarily from the eastern Chukchi Sea, whereas the 20092011 RUSALCA/ICESCAPE expeditions sampled across the region into Russian waters of the Chukchi Sea and East Siberian Sea. Thus the $\Omega_{\text {aragonite }}$ difference between years may relate to differences in sampling location and a bias to sampling waters more influenced by Alaskan Coastal Current water (i.e., with higher $\Omega_{\text {aragonite }}$ as shown in Fig. 4) during the 2002-2004 SBI project. 


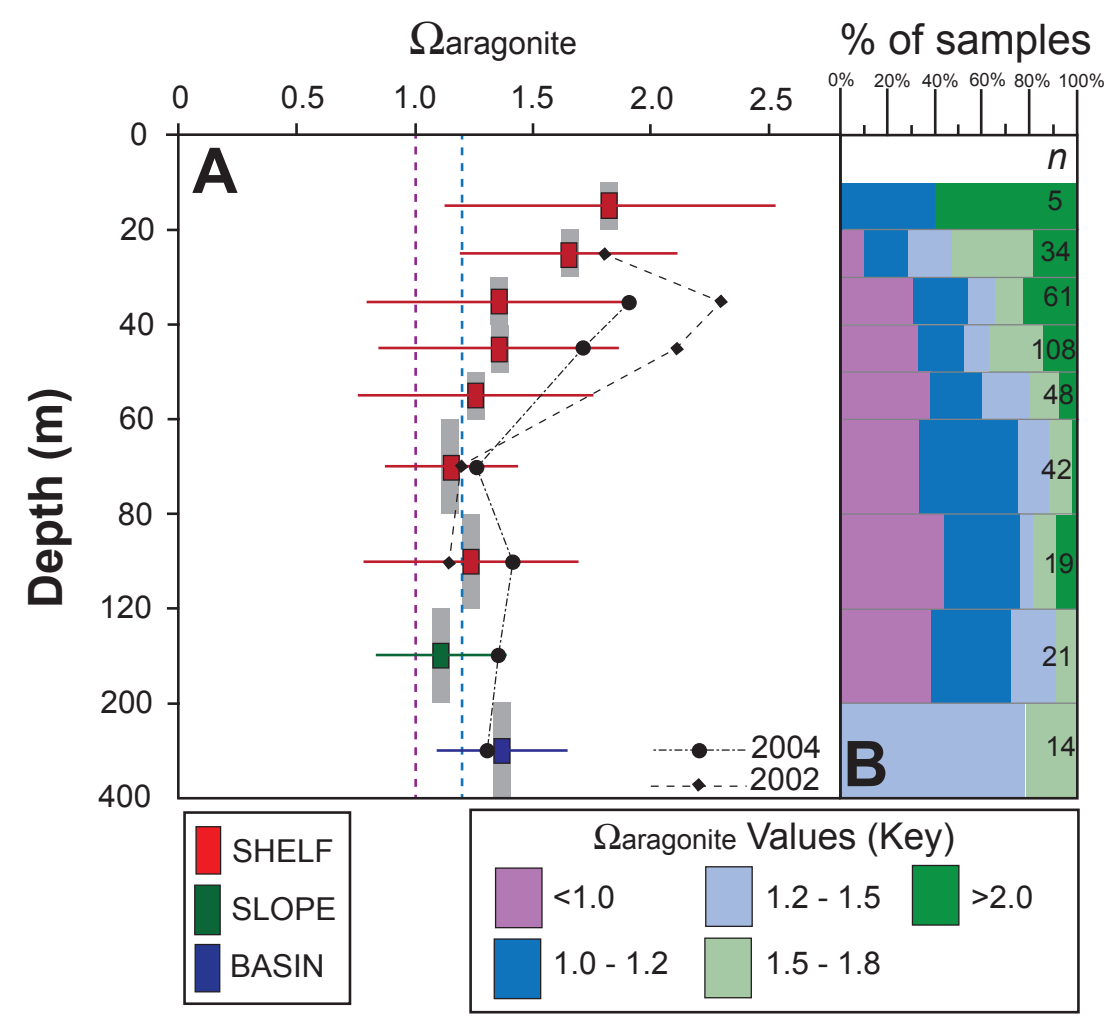

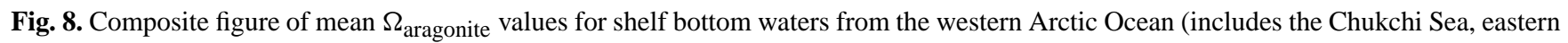
East Siberian Sea, western Beaufort Sea shelf) as observed during the 2009-2011 RUSALCA/ICESCAPE expeditions. Limited data from

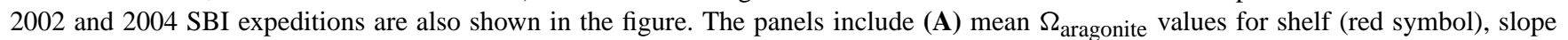
and basin for different depth intervals. The standard deviation of mean shelf $\Omega_{\text {aragonite }}$ at each depth interval is shown in light red, and gives

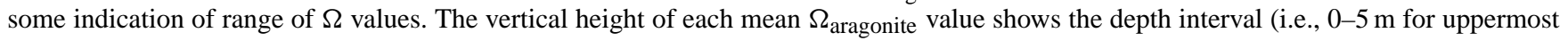
depth interval); (B) the \% of sampled water within the defined $\Omega$ ranges (i.e., $<1.0$ is shown as purple; $1.0-1.2$ as deep blue; $1.2-1.5$ light

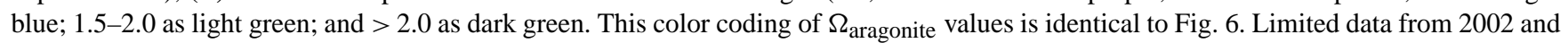
2004 SBI expeditions are also shown in the figure. In (B), the number of samples (i.e., $n$ of sample within the depth horizon) that comprise each binned depth horizon is given in the right-hand corner of each depth bin, replicating $n$ values given in Table 1 .

In Table 1, we compare mean $\Omega_{\text {aragonite }}$ values at different depth intervals for shelf (i.e., Chukchi Sea and East Siberian Sea), slope (i.e., Chukchi Sea) and basin waters (i.e. Canada Basin) for the 2002 to 2011 period. It should be noted that there was a small sampling size for a substantial number of depth intervals for the 2002 and 2004 SBI expeditions. For shelf water, the mean values in the upper $15 \mathrm{~m}$ and below $50 \mathrm{~m}$ were similar. However, $\Omega_{\text {aragonite }}$ values were generally lower by 0.1 to 0.4 in the $15-50 \mathrm{~m}$ depth interval during the period 2009-2011. Although few bottom-water samples were collected during the SBI expeditions, the mean bottomwater $\Omega_{\text {aragonite }}$ is lower by $>0.1-0.2$ during the later 20092011 period (Fig. 8). This suggests that shelf bottom waters and the benthos between $\sim 20$ and $50 \mathrm{~m}$ deep have been exposed to low $\Omega_{\text {aragonite }}$ values (e.g., $<1.2$ ) during the last few years.

The mean $\Omega_{\text {aragonite }}$ of slope waters, primarily on the northern slope of the Chukchi Sea, also appears to have decreased by $\sim 0.1-0.5$ in the upper $100 \mathrm{~m}$, with similar
$\Omega_{\text {aragonite }}$ values in deeper waters observed over the last decade (100-200 m; Fig. 6; Table 1). In Canada Basin waters, a similar $\Omega_{\text {aragonite }}$ decline of $\sim 0.2-0.5$ was also observed in the upper $50 \mathrm{~m}$, with little apparent change deeper in the water column (i.e., 100-400 m; Fig. 6; Table 1). The caveat to such assessments is that relatively few data were collected during the SBI expeditions and any comparison between years likely reflects changes associated with different sampling locations and seasonal timing of data collection, for example.

\subsection{Surface enhancement and subsurface suppression of $\mathrm{CaCO}_{3}$ saturation states}

Previous observations in slope waters of the Chukchi Sea shelf during the SBI project between 2002 and 2004 (Bates et al., 2009) showed a spring to summertime enhancement of $\Omega$ values in surface waters and reduction of subsurface water $\Omega$, respectively, during the sea-ice-free period compared to "winter/early-spring" conditions under sea-ice cover. The 
seasonal divergence in $\Omega$ values for summertime surface and subsurface waters of the western Arctic from winter/earlyspring conditions was suggested to result from changes in seawater $\mathrm{CO}_{2}$-carbonate chemistry imparted by seasonal biological processes such as primary production and respiration/remineralization of organic carbon, during the sea-ice retreat period (Bates et al., 2009). Similar interactions and feedbacks between biological processes and seawater $\mathrm{CO}_{2}$ carbonate chemistry have also been observed in other openocean and coastal environments over different timescales (e.g., diurnal to seasonal), including open-ocean waters of the North Pacific (Feely et al., 1988), in subtropical coral reefs ecosystems due to $\mathrm{CaCO}_{3}$ production and dissolution (Bates et al., 2010), and within anthropogenically perturbed estuaries (Feely et al., 2010), for example.

In the northern Chukchi Sea, the seasonal divergence and perturbation from winter/early-spring conditions of surface and subsurface $\Omega$ was described as evidence for a phytoplankton-carbonate saturation state ("PhyCaSS") interaction (Bates et al., 2009). Similar seasonal interactions between biological processes and seawater $\mathrm{CO}_{2}$-carbonate chemistry have been observed on the Bering Sea shelf (Mathis et al., 2010). In simple terms, the PhyCASS interaction is a variant model of the well-known biological pump of carbon with a focus on $\Omega$ dynamics within a seaice-influenced shallow shelf rather than focused on DIC or $p \mathrm{CO}_{2}$ variability. In shelf and slope waters of the northern Chukchi Sea, very high rates of marine phytoplankton primary production observed during the sea-ice-free period (e.g., Hill and Cota, 2005) results in reduction of seawater DIC and $p \mathrm{CO}_{2}$ (e.g., Bates et al., 2005a, 2011; Pipko et al., 2011) through uptake of $\mathrm{CO}_{2}$ by phytoplankton photosynthesis in surface waters. Seawater $\mathrm{CO}_{2}$-carbonate equilibria dictate that uptake of $\mathrm{CO}_{2}$ via phytoplankton photosynthesis acts to increase the $\mathrm{pH}$ and $\Omega$ of surface waters, with this process seasonally mitigating the long-term, cumulative reduction of $\mathrm{pH}$ and $\Omega$ to the present day due to gradual ocean acidification on the slope waters of the Chukchi Sea (Bates et al., 2009). In the western Arctic, summertime high rates of phytoplankton primary production also result in large vertical export of organic carbon to the subsurface and seafloor (e.g., Moran et al., 2005) and horizontal transport of organic carbon off the shelves into the deep Canada Basin (Bates et al., 2005b). In the PhyCASS interaction, remineralization of organic matter back to $\mathrm{CO}_{2}$ (which acts to decrease $\mathrm{pH}$ and $\Omega$ ) in subsurface waters of the northern shelf and slope waters was invoked to explain the seasonal subsurface reduction of $\mathrm{pH}$ and $\Omega$ in subsurface waters. On seasonal timescales, this biological process augments the reduction of $\mathrm{pH}$ and $\Omega$ due to gradual ocean acidification with subsequent fall homogenization of the water column through mixing during the winter freeze-up "resetting" seawater $\mathrm{CO}_{2}$-carbonate chemistry to winter/early-spring conditions (Bates et al., 2009). In this study, as explanation for our observations collected during the RUSALCA and ICESCAPE projects, we expand on the PhyCaSS treatment and use a simple mass balance model to include other physico-biogeochemical processes that can impact seawater $\mathrm{CO}_{2}$-carbonate chemistry, including air-sea $\mathrm{CO}_{2}$ gas exchange, and sea-ice melt and freshening. Potential changes in physico-biogeochemical conditions are discussed later in light of the apparent expansion of the low- $\Omega$ bottom water in the western Arctic during the last decade.

\subsubsection{Physico-biogeochemical processes that influence $\Omega$}

As discussed above, physico-biogeochemical processes directly impact seawater $\mathrm{CO}_{2}$-carbonate equilibria, thereby modifying such parameters as DIC, TA, $p \mathrm{CO}_{2}, \mathrm{pH}$ and $\Omega$ (e.g., Zeebe and Wolf-Gladrow, 2002). Since this paper is focused on seasonal changes in $\Omega$, it is useful to plot $\Omega$ (here $\Omega_{\text {aragonite }}$ ) against DIC and TA to show the relative direction of changes imparted by the dominant physico-biogeochemical processes in the western Arctic (Fig. 9). In Fig. 9, the range of $\Omega_{\text {aragonite }}$ is shown against DIC and TA in the western Arctic with observed 2009-2011 RUSALCA/ICESCAPE data plotted within the dashed line on the figure. The directions of $\Omega_{\text {aragonite }}$ change imparted by physico-biogeochemical processes are shown relative to winter/early-spring shelf water (temperature $=-0.41 \pm 1.72{ }^{\circ} \mathrm{C} ; \quad$ salinity $32.38 \pm 0.96$; $\mathrm{TA}=2243.8 \pm 60.8 \mu \mathrm{mol} \mathrm{kg}-1 ; \quad$ DIC $=2130 \mu \mathrm{mol} \mathrm{kg}-1 ;$ salinity $=32.58 ;$ temperature $=-0.41^{\circ} \mathrm{C}$; Table 2) with the caveat that the direction of $\Omega_{\text {aragonite }}$ change will alter slightly depending on starting point of seawater $\mathrm{CO}_{2}$-carbonate chemistry. The rationale for the choice of winter/early-spring condition is described later in Sect. 4.2.2. $\Omega_{\text {aragonite }}$ changes are shown in Fig. 9, but $\Omega_{\text {calcite }}$ changes could be similarly shown also. Another important caveat is that the plot of $\Omega$ against DIC and TA shown in Fig. 9 cannot show all of the changes imparted by physico-biogeochemical processes (e.g., temperature and changes in $\mathrm{CaCO}_{3}$ solubility with ionic strength), but these exceptions will be discussed later.

Those physico-biogeochemical processes that act to $d e$ crease DIC and $p \mathrm{CO}_{2}$, and increase $\mathrm{pH}$ and $\Omega$ include the following: (a) photosynthesis or primary production (i.e., net community production, $\mathrm{NCP}$ ); and (b) loss of $\mathrm{CO}_{2}$ from surface waters due to air-sea gas exchange of $\mathrm{CO}_{2}$ in those areas that are sources of $\mathrm{CO}_{2}$ to the atmosphere (see Fig. 9a). This assumes that temperature and salinity remain constant and that the latter process (i.e., air-sea $\mathrm{CO}_{2}$ gas exchange) does not alter TA. The uptake of nitrate by phytoplankton photosynthesis increases TA (Brewer and Goldman, 1976) with the net result that $\Omega_{\text {aragonite }}$ (or $\Omega_{\text {calcite }}$ ) increases slightly by $\sim 0.01$ per $1 \mu \mathrm{mol} \mathrm{kg}{ }^{-1}$ nitrate uptake.

Those physico-biogeochemical processes that act to increase DIC and $p \mathrm{CO}_{2}$, and decrease $\mathrm{pH}$ and $\Omega$ (i.e., assuming that temperature and salinity remain constant) include the following: (c) respiration or remineralization of organic 

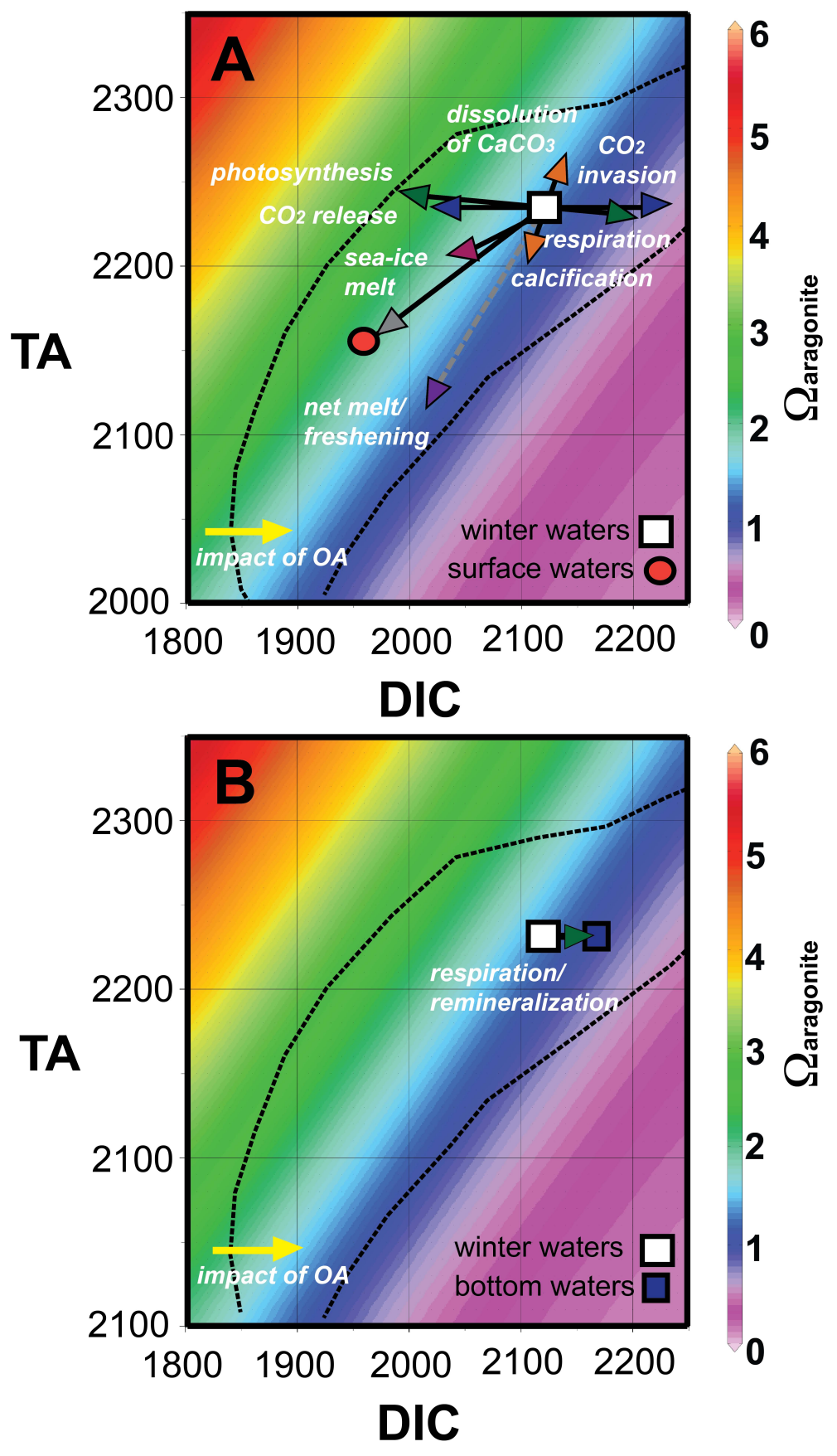

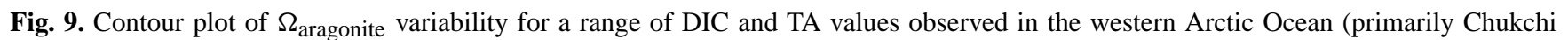
Sea but also eastern East Siberian Sea and western Beaufort Sea) with the relative direction of changes imparted by the dominant physicobiogeochemical drivers in the region (shown by arrows). Nearly all RUSALCA/ICESCAPE $\Omega_{\text {aragonite }}$ data fall within the dashed line shown (surface waters, A, and subsurface seasonal changes, B). The directions of $\Omega_{\text {aragonite }}$ change imparted by physico-biogeochemical processes are shown for "typical" spring shelf water $\left(\mathrm{TA}=2200 \mu \mathrm{mol} \mathrm{kg}-1\right.$; $\mathrm{DIC}=2000 \mu \mathrm{mol} \mathrm{kg}-1$; salinity $=33$; temperature $\left.=-1^{\circ} \mathrm{C}\right)$ with the caveat that the direction of $\Omega_{\text {aragonite }}$ change will alter slightly depending on the starting point of seawater carbonate chemistry. $\Omega_{\text {aragonite }}$ changes are shown in Fig. 7, but $\Omega_{\text {calcite }}$ changes could be similarly shown also. Another important caveat is that the plot of $\Omega$ against DIC and TA does not show all of the changes imparted by physico-biogeochemical processes (e.g., temperature and changes in $\mathrm{CaCO}_{3}$ solubility with ionic strength), but these exceptions are discussed in the paper. The arrows denote direction of $\Omega$ change due to individual/combined processes, but arrow length does not denote magnitude of $\Omega$ change. Photosynthesis, primary production and loss of $\mathrm{CO}_{2}$ from surface waters due to gas exchange increase $\Omega$. Calcification/dissolution of $\mathrm{CaCO}_{3}$, warming and cooling, and freshening of the mixed layer have minor impact on $\Omega$. Respiration, remineralization of organic carbon to $\mathrm{CO}_{2}$ and gain of $\mathrm{CO}_{2}$ by surface waters due to gas exchange decrease $\Omega$. 
Table 2. Mean remnant "winter/early-spring" physical conditions, nutrient concentrations and seawater $\mathrm{CO}_{2}$-carbonate chemistry for 2002-2004 SBI data (May to early June) and 2009-2011 RUSALCA/ICESCAPE summer data. In B, the mean seawater CO ${ }_{2}$-carbonate chemistry of surface summertime and winter/early-spring water remnant of the shelf during summertime are compared.

\begin{tabular}{|c|c|c|c|c|c|c|c|c|c|}
\hline & Temp & $\begin{array}{c}\text { Salinity } \\
\left({ }^{\circ} \mathrm{C}\right)\end{array}$ & $\begin{array}{c}\mathrm{NO}_{3} \\
\left(\mu \mathrm{mol} \mathrm{kg}^{-1}\right)\end{array}$ & $\begin{array}{c}\text { Oxygen } \\
\left(\mu \mathrm{mol} \mathrm{kg}^{-1}\right)\end{array}$ & $\begin{array}{c}\text { DIC } \\
\left(\mu \mathrm{mol} \mathrm{kg}^{-1}\right)\end{array}$ & $\begin{array}{c}n \mathrm{DIC} \\
\left(\mu \mathrm{mol} \mathrm{kg}^{-1}\right)\end{array}$ & $\begin{array}{c}\text { TA } \\
\left(\mu \mathrm{mol} \mathrm{kg}^{-1}\right)\end{array}$ & $\begin{array}{c}n \mathrm{TA} \\
\left(\mu \mathrm{mol} \mathrm{kg}^{-1}\right)\end{array}$ & $\Omega_{\text {aragonite }}$ \\
\hline \multicolumn{10}{|l|}{ A. Subsurface } \\
\hline \multicolumn{10}{|c|}{ Shelf subsurface winter water $(30-60 \mathrm{~m} ; \sim 100 \%$ sea-ice cover $)$} \\
\hline Spring 2002 & $-1.64 \pm 0.28$ & $32.54 \pm 0.71$ & $9.08 \pm 2.90$ & $327.8 \pm 23.2$ & $2158.7 \pm 44.6$ & $2327.2 \pm 14.2$ & $2288.7 \pm 42.6$ & $2466.5 \pm 35.9$ & $1.49 \pm 0.36$ \\
\hline Spring 2004 & $-1.54 \pm 0.30$ & $32.23 \pm 0.84$ & $7.81 \pm 4.38$ & $347.1 \pm 32.3$ & $2127.4 \pm 37.1$ & $2310.4 \pm 30.4$ & $2243.8 \pm 25.0$ & $2437.0 \pm 31.9$ & $1.37 \pm 0.29$ \\
\hline \multicolumn{10}{|c|}{ Shelf subsurface summer water ( $30-60 \mathrm{~m} ; 35-40 \mathrm{~m}$ only) } \\
\hline Summer 2002 & $-0.77 \pm 1.63$ & $32.36 \pm 0.58$ & $8.34 \pm 5.36$ & $317.9 \pm 39.4$ & $2128.7 \pm 62.9$ & $2294.0 \pm 52.3$ & $2262.9 \pm 28.6$ & $2442.1 \pm 23.6$ & $1.53 \pm 0.51$ \\
\hline Summer 2004 & $-0.02 \pm 2.44$ & $32.29 \pm 0.62$ & $7.63 \pm 5.56$ & $336.3 \pm 24.3$ & $2098.2 \pm 58.8$ & $2270.5 \pm 32.0$ & $2227.0 \pm 22.9$ & $2407.0 \pm 22.6$ & $1.47 \pm 0.46$ \\
\hline $\begin{array}{l}\text { Summer } \\
(2009-2011)\end{array}$ & $-0.41 \pm 1.72$ & $32.58 \pm 0.96$ & $7.91 \pm 5.86$ & $329.3 \pm 29.8$ & $2130.0 \pm 92.1$ & $2293.2 \pm 66.6$ & $2243.8 \pm 60.8$ & $2413.6 \pm 29.6$ & $1.35 \pm 0.50$ \\
\hline \multicolumn{10}{|c|}{ Bering Strait subsurface summer water $(35-45 \mathrm{~m})$} \\
\hline AW 2010 & +0.28 & 32.38 & 10.13 & $\mathrm{n} / \mathrm{a}$ & 2036.41 & 2201.1 & 2205.9 & 2384.2 & 1.82 \\
\hline ACC 2009 & $\mathrm{n} / \mathrm{a}$ & $\mathrm{n} / \mathrm{a}$ & $\mathrm{n} / \mathrm{a}$ & $\mathrm{n} / \mathrm{a}$ & 1978.5 & $\mathrm{n} / \mathrm{a}$ & 2180.3 & $\mathrm{n} / \mathrm{a}$ & $\mathrm{n} / \mathrm{a}$ \\
\hline ACC 2010 & +2.18 & 32.11 & 0.21 & $\mathrm{n} / \mathrm{a}$ & 2005.5 & 2186.4 & 2216.0 & 2415.8 & 2.20 \\
\hline ACC 2011 & +2.46 & 31.15 & 5.43 & 378.2 & 2015.1 & 2239.8 & 2207.3 & 2453.8 & 2.06 \\
\hline \multicolumn{10}{|c|}{ B. Comparison of subsurface and surface shelf water $(0-15 \mathrm{~m} ; 35-40 \mathrm{~m}$ only) } \\
\hline $\begin{array}{l}\text { Surface } \\
(2009-2011)\end{array}$ & $+2.14 \pm 2.39$ & $30.77 \pm 1.63$ & $0.53 \pm 1.57$ & $378.5 \pm 45.1$ & $1951.6 \pm 74.9$ & $2221.8 \pm 85.8$ & $2154.5 \pm 90.5$ & $2441.5 \pm 53.5$ & $2.10 \pm 0.54$ \\
\hline Subsurface & $-0.41 \pm 1.72$ & $32.58 \pm 0.96$ & $7.91 \pm 5.86$ & $329.3 \pm 29.8$ & $2130.0 \pm 92.1$ & $2293.2 \pm 66.6$ & $2243.8 \pm 60.8$ & $2413.6 \pm 29.6$ & $1.35 \pm 0.50$ \\
\hline
\end{tabular}

carbon back to $\mathrm{CO}_{2}$; and (d) gain of $\mathrm{CO}_{2}$ in surface waters due to air-sea gas exchange of $\mathrm{CO}_{2}$ in those areas that are oceanic sinks of $\mathrm{CO}_{2}$ from the atmosphere (Fig. 9a). In the former process, regeneration of nitrate through remineralization of organic matter decreases $\Omega_{\text {aragonite }}$ (or $\Omega_{\text {calcite }}$ ) by $\sim 0.01$ per $1 \mu \mathrm{mol} \mathrm{kg}^{-1}$ nitrate released.

Other physico-biogeochemical processes can act in either direction, increasing/decreasing DIC, $p \mathrm{CO}_{2}, \mathrm{pH}$ and $\Omega$. These include the following: (e) freshening of the mixed layer due to sea-ice melt, precipitation, or riverine input (Fig. 9a); and (f) vertical mixing and diffusion, as well as horizontal mixing. Other physico-biogeochemical processes have relevance in the western Arctic but, as described later, are likely to have minor impacts on $\Omega$ (and $\mathrm{pH}$ ). They include (g) calcification and dissolution of $\mathrm{CaCO}_{3}$ and (h) warming or cooling (for example, a $10^{\circ} \mathrm{C}$ temperature change imparts a 0.1 change in $\Omega$, but since this does not change TA and DIC no arrow can be shown in Fig. 9a). Calcification, in the absence of other physico-biogeochemical processes, decreases TA : DIC in the ratio of $2: 1$, thereby increasing $\Omega$ slightly, with dissolution of $\mathrm{CaCO}_{3}$ having the opposite effect.

\subsubsection{Simple mass balance model for understanding seasonal changes in $\Omega$}

Here, we construct a simple mass balance model to examine the primary causes for the short-term, seasonal perturbation in seawater $\mathrm{CO}_{2}$-carbonate chemistry from winter/earlyspring to summertime conditions during sea-ice retreat. It should be noted that this mass balance model examines mean changes in seawater $\mathrm{CO}_{2}$-carbonate chemistry to highlight the dominant and relative influence of physico- biogeochemical processes that are likely controlling $\Omega$ in the shelf waters of the Chukchi Sea. It is not a detailed physicalbiological dynamic model assessment; both approaches have their advantages and disadvantages. We also show the longterm influence on $\Omega$ in surface and subsurface waters imparted by ocean acidification due to anthropogenic $\mathrm{CO}_{2}$ uptake (i.e., $\Sigma \Omega_{\mathrm{CANT}}$ ). Thus, superimposed on gradual changes in $\Omega$, cumulative to the present day, caused by ocean acidification, are seasonal changes influenced by the following.

In surface waters, the potential changes due to seasonal forcing on $\Omega$ due to different physico-biogeochemical processes can be estimated by determining changes in DIC $\left(\triangle D I C{ }^{\text {SURFACE }}\right)$ and $\Omega$ values $\left(\Delta \Omega^{\text {SURFACE }}\right)$ from winter/early-spring to summertime conditions during the sea-ice retreat. Here, $\triangle D I C^{\text {SURFACE }}$ and $\Delta \Omega^{\text {SURFACE }}$ reflects the following:

$$
\triangle \mathrm{DIC}^{\mathrm{SURFACE}}={ }^{\text {MEAN }} \mathrm{DIC}_{(35-40 \mathrm{~m})}-{ }^{\mathrm{MEAN}} \mathrm{DIC}_{(0-20 \mathrm{~m})}
$$

$\Delta \Omega^{\text {SURFACE }}={ }^{\text {MEAN }} \Omega_{(35-40 \mathrm{~m})}-{ }^{\text {MEAN }} \Omega_{(0-20 \mathrm{~m})}$,

where ${ }^{\text {MEAN DIC }}(35-40 \mathrm{~m})$ and ${ }^{\mathrm{MEAN}} \Omega_{(35-40 \mathrm{~m})}$ are mean DIC and $\Omega$ values at $35-40 \mathrm{~m}$ deep and ${ }^{\mathrm{MEAN}} \mathrm{DIC}_{(0-20 \mathrm{~m})}$ and MEAN $\Omega_{(0-20 \mathrm{~m})}$ are mean DIC and $\Omega$ values in the mixed layer (Table 2; Fig. 11a). In Eq. (1) and those following,

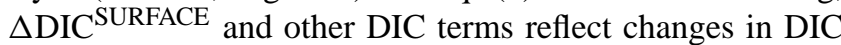
normalized to a salinity of 32.58 .

The physico-biogeochemical components that contribute to $\triangle \mathrm{DIC} \mathrm{SURFACE}^{\mathrm{and}} \Delta \Omega^{\mathrm{SURFACE}}$ are expressed by the 
Seasonal changes in $\Omega$ aragonite

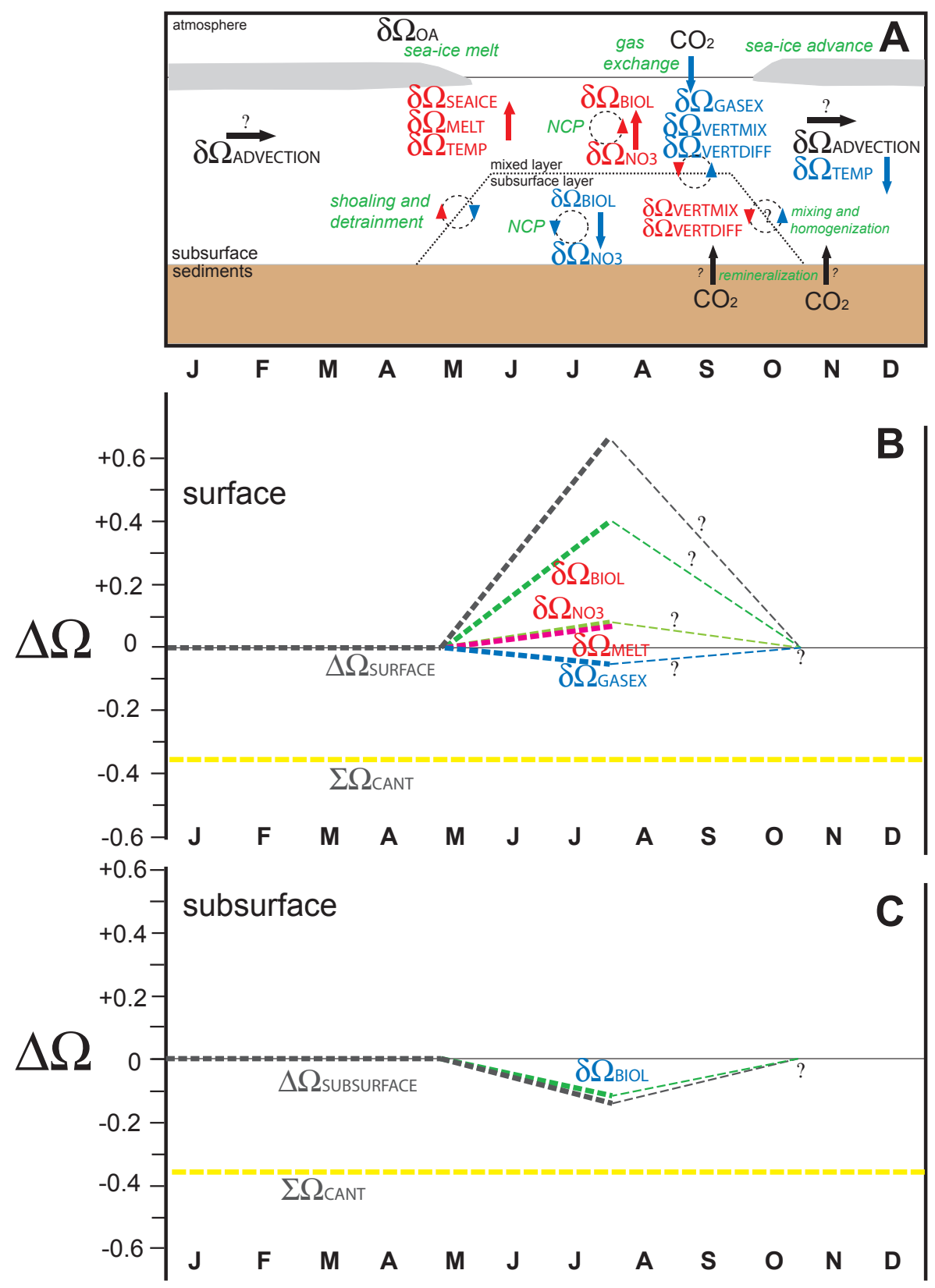

Fig. 10. Conceptual model of seasonal changes in seawater $\mathrm{CO}_{2}$-carbonate chemistry on the western Arctic shelves. This hypothesized paradigm shows impact of ocean acidification and biological/physical processes on $\Omega$ values for aragonite. It should be stressed that the $\Omega$ changes shown reflect "seasonal" changes only (e.g., $\delta \Omega_{\mathrm{BIOL}}, \delta \Omega_{\mathrm{GASEX}}$, and $\delta \Omega_{\mathrm{TEMP}}$ ), while $\Sigma \Omega_{\mathrm{CANT}}$ the cumulative change in $\Omega$ due to the emission of anthropogenic $\mathrm{CO}_{2}$ from pre-industrial times to present (i.e., $\Sigma \Omega_{\mathrm{CANT}}$ ) is shown for comparison. In all three panels, bottom-axis J to D denotes January to December. The red or blue arrows denote increase or decrease in $\Omega$. (A) Annual schematic of changes in $\Omega_{\text {aragonite }}$ on shelf waters of the western Arctic Ocean. The sea-ice-free period is approximately 3-4 months. Shelf waters are well mixed during the sea-ice-covered period, with mixed layer developing in late spring due to warming and sea-ice melt, and erosion of the mixed layer in September-October due to convective mixing and homogenization of shelf waters during fall cooling and sea-ice advance. The $\delta \Omega_{\mathrm{OA}}$, $\delta \Omega_{\mathrm{BIOL}}, \delta \Omega_{\mathrm{GASEX}}$, and $\delta \Omega_{\mathrm{TEMP}}$ terms are shown in the figure with general direction of forcing of $\Omega$. (B) Annual schematic changes in $\Omega_{\text {aragonite }}$ of surface waters. The red line denotes total change in $\Omega$ (i.e., $\Delta \Omega^{\text {SURFACE }}$, while other terms are denoted as follows: $\Sigma \Omega_{\mathrm{CANT}}$ (yellow), $\delta \Omega_{\mathrm{BIOL}}$ (dark green), $\delta \Omega_{\mathrm{GASEX}}$ (blue), and $\delta \Omega_{\mathrm{MELT}}$ (purple). (C) Annual schematic changes in $\Omega_{\text {aragonite }}$ of subsurface waters. The red line denotes total change in $\Omega$ (i.e., $\Delta \Omega^{\text {SUBSURFACE }}$ ), while other terms are denoted as follows: $\delta \Omega_{\mathrm{BIOL}}$ (dark green). 


\section{SURFACE WATERS}
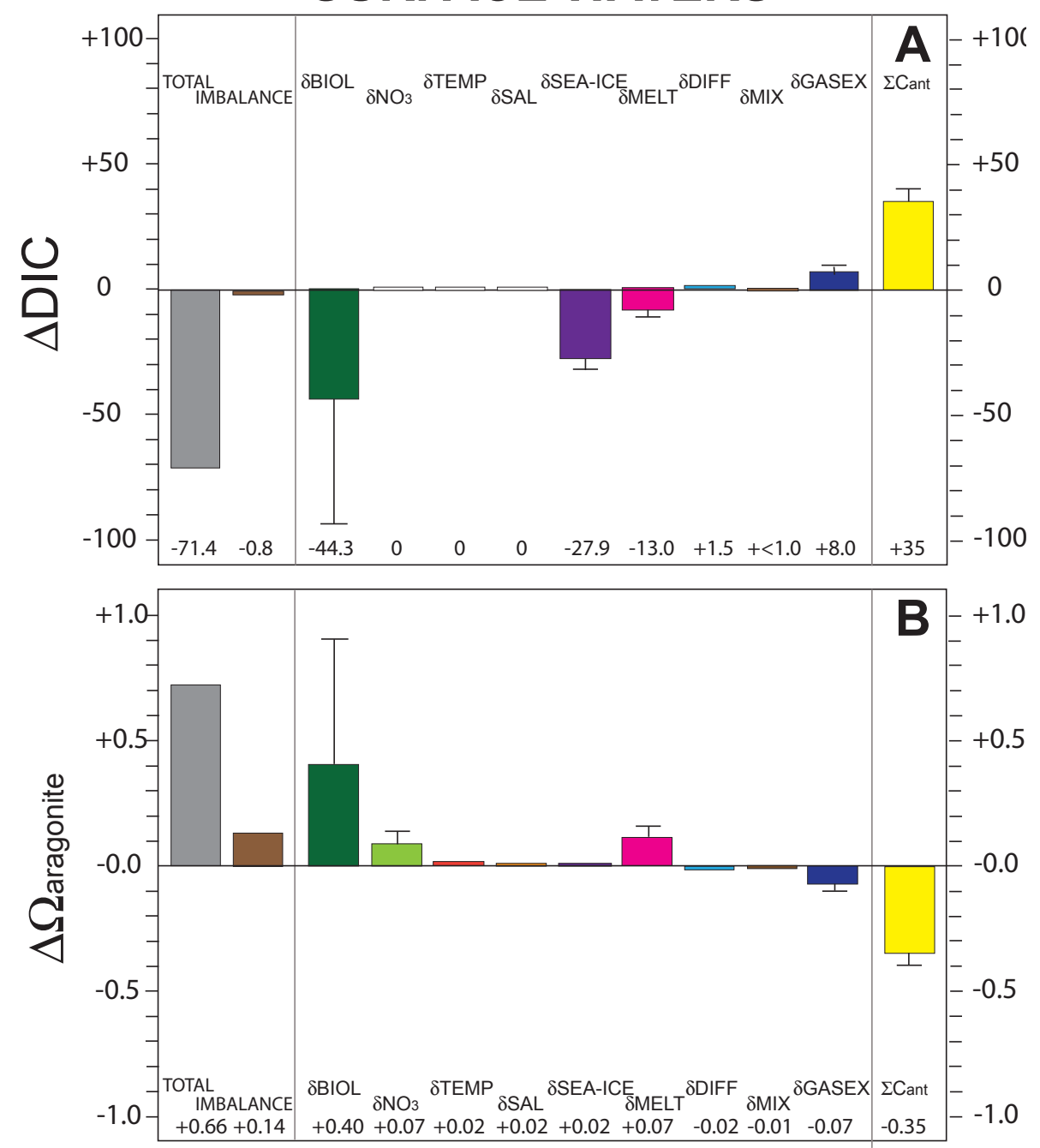

Fig. 11. Winter/early-spring to summertime changes in surface water DIC ( $\triangle \mathrm{DIC}$ SURFACE; grey) and $\Omega\left(\Delta \Omega^{\mathrm{SURFACE}}\right.$; grey) using mean winter/early-spring to summertime changes in seawater $\mathrm{CO}_{2}$-carbonate chemistry values reported in Table 3 . The imbalance in both terms is shown in brown. (A) This panel shows the mean impact on DIC as described in Eq. (3) of $\delta \mathrm{DIC}_{\mathrm{BIOL}}($ green$), \delta \mathrm{DIC} \mathrm{NO}_{3}$ (light green), $\delta \mathrm{DIC}_{\mathrm{TEMP}}$ (red), $\delta \mathrm{DIC}_{\mathrm{SALINITY}}$ (orange), $\delta \mathrm{DIC}_{\mathrm{SEAICE}}$ (purple), $\delta \mathrm{DIC}_{\mathrm{MELT}}$ (pink), $\delta \mathrm{DIC}_{G A S E X}$ (blue), $\delta \mathrm{DIC} \mathrm{VERTDIFF}_{\text {(cyan), and }}$ $\delta$ DIC VERTMIXING (dark brown). The $\delta$ DIC ADVECTION cannot be determined and likely contributes to the imbalance. (B) This panel shows the mean impact on $\Omega$ as described in Eq. (4) of $\delta \Omega_{\mathrm{BIOL}}, \delta \Omega_{\mathrm{NO}_{3}}, \delta \Omega_{\mathrm{TEMP}}, \delta \Omega_{\mathrm{SALINITY}}, \delta \Omega_{\mathrm{SEAICE}}, \Omega_{\mathrm{MELT}}, \delta \Omega_{\mathrm{VERTDIFF}}$,

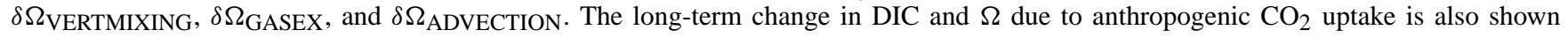
for reference to the short-term, seasonal changes ( $\Sigma \Omega_{\text {CANT }}$, yellow).

following equations:

$$
\begin{aligned}
& \Delta \mathrm{DIC}^{\mathrm{SURFACE}}=\delta \mathrm{DIC}_{\mathrm{BIOL}}+\delta \mathrm{DIC}_{\mathrm{NO}_{3}}+\delta \mathrm{DIC}_{\mathrm{TEMP}} \\
& +\delta \mathrm{DIC}_{\text {SALINITY }}+\delta \mathrm{DIC}_{\text {SEAICE }}+\delta \mathrm{DIC}_{\text {MELT }} \\
& +\delta \mathrm{DIC}_{\mathrm{GASEX}}+\delta \mathrm{DIC}_{\text {VERTDIFF }}+\delta \mathrm{DIC}_{\text {VERTMIXING }} \\
& +\delta \mathrm{DIC}_{\mathrm{ADVECTION}}
\end{aligned}
$$

$$
\begin{aligned}
& \Delta \Omega^{\text {SURFACE }}=\delta \Omega_{\mathrm{BIOL}}+\delta \Omega_{\mathrm{NO}_{3}}+\delta \Omega_{\mathrm{TEMP}}+\delta \Omega_{\mathrm{SALINITY}} \\
& +\delta \Omega_{\mathrm{SEAICE}}+\delta \Omega_{\mathrm{MELT}}+\delta \Omega_{\mathrm{GASEX}}+\delta \Omega_{\mathrm{VERTDIFF}} \\
& +\delta \Omega_{\mathrm{VERTMIXING}}+\delta \Omega_{\mathrm{ADVECTION}}
\end{aligned}
$$

where $\triangle \mathrm{DIC} \mathrm{CURACE}^{\mathrm{S}}$ and $\Delta \Omega^{\mathrm{SURFACE}}$ are the changes in DIC and $\Omega$ from winter to summertime, respectively. With detailed explanations later in the text, the terms in Eqs. (3) and (4) reflect changes due to net community production (i.e., $\delta \mathrm{DIC} \mathrm{BIOL}_{\mathrm{B}}$ ), nitrate uptake/release(i.e., $\delta \mathrm{DIC}_{\mathrm{NO}_{3}}$ ), temperature (i.e., $\delta \mathrm{DIC}_{\mathrm{TEMP}}$ ), salinity (i.e., $\delta \mathrm{DIC}_{\mathrm{SALINTY}}$ ), sea-ice contributions (i.e., $\delta$ DIC $\mathrm{CSEICE}_{\text {), }}$ under-ice melt contributions (i.e., $\delta \mathrm{DIC}_{\mathrm{MELT}}$ ), air-sea $\mathrm{CO}_{2}$ gas exchange

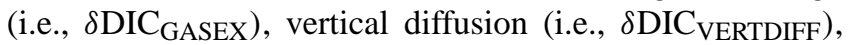
vertical mixing (i.e., $\delta$ DIC $_{\text {VERTMIX }}$ ), and advection (i.e., $\delta \mathrm{DIC}_{\mathrm{ADVECTION}}$ ), respectively (Fig. 10). In Eq. (3), 
several of the DIC terms are helpful for determining $\Omega$ terms in Eq. (4). Furthermore in Eq. (3), several terms are zero. For example, since the $\triangle \mathrm{DIC} \mathrm{SURFACE}^{\mathrm{S}}$ term and terms in Eq. (3) reflect changes in DIC normalized to a salinity of 32.58, $\delta \mathrm{DIC}_{\text {SALINITY }}=0$. Furthermore, in Eq. (3) processes such as warming/cooling do not change DIC $\left(\delta \mathrm{DIC}_{\mathrm{TEMP}}=0\right)$, while changes in nitrate do not directly alter DIC $\left(\delta \mathrm{DIC}_{\mathrm{NO}_{3}}=0\right)$. Thus, Eq. (3) can be abbreviated to

$$
\begin{aligned}
& \Delta \mathrm{DIC}^{\text {SURFACE }}=\delta \mathrm{DIC}_{\mathrm{BIOL}}+\delta \mathrm{DIC}_{\text {SEAICE }}+\delta \mathrm{DIC}_{\text {MELT }} \\
& +\delta \mathrm{DIC}_{\mathrm{GASEX}}+\delta \mathrm{DIC}_{\text {VERTDIFF }}+\delta \mathrm{DIC}_{\text {VERTMIXING }} \\
& +\delta \mathrm{DIC}_{\text {ADVECTION }} .
\end{aligned}
$$

The terms in Eqs. (3) and (5) are expressed in $\mu \mathrm{mol} \mathrm{kg} \mathrm{kg}^{-1}$, while $\Omega$ terms have no units.

As stated earlier the $\triangle \mathrm{DIC}$ SURFACE and $\Delta \Omega^{\text {SURFACE }}$ terms reflect changes from winter/early-spring to summertime conditions (i.e., $\mathrm{DIC}_{\text {winter }}-\mathrm{DIC}_{\text {summer }}=\Delta \mathrm{DIC}^{\mathrm{SURFACE}}=$ $\left.\operatorname{MEAN} \operatorname{DIC}_{(35-40 \mathrm{~m})}-{ }^{\mathrm{MEAN}} \mathrm{DIC}_{(0-20 \mathrm{~m})}\right)$. Here, we use the seawater $\mathrm{CO}_{2}$-carbonate chemistry of shelf water from 35 to $40 \mathrm{~m}$ collected during the 2009-2011 RUSALCA/ICESCAPE expeditions as the best representative of remnant winter/early-spring water; it is cold (mean of $-0.43^{\circ} \mathrm{C}$ ) and has a mean salinity of $\sim 32.6$ and nitrate content of $7.9 \pm 1.0 \mu \mathrm{mol} \mathrm{kg}{ }^{-1}$ (Table 2). This remnant winter/early-spring water has physico-biogeochemical and seawater $\mathrm{CO}_{2}$-carbonate chemistry properties very similar to winter water observed on the shelf during spring 2002-2004 SBI cruises and summertime water present at $30-60 \mathrm{~m}$ deep during summertime SBI cruises (Bates et al., 2005a; Table 2). The spring SBI observations were generally conducted under 90-100\% sea-ice cover and a well-mixed water column before substantial seasonal stratification. This winter/early-spring remnant is also present as Anadyr Water at Bering Strait.

In subsurface waters, the $\triangle \mathrm{DIC} \mathrm{C}^{\mathrm{SUBSURFACE}}$ and $\Delta^{\text {SUBSURFACE }}$ terms reflects the following:

$\triangle$ DIC $^{\text {SUBSURFACE }}={ }^{\text {MEAN }} \operatorname{DIC}_{(35-40 \mathrm{~m})}-{ }^{\text {MEAN }} \operatorname{DIC}_{(50-70 \mathrm{~m})}$

$\Delta \Omega^{\text {SUBSURFACE }}={ }^{\text {MEAN }} \Omega_{(35-40 \mathrm{~m})}-{ }^{\text {MEAN }} \Omega_{(0-20 \mathrm{~m})}$,

where ${ }^{\text {MEAN DIC }}(35-40 \mathrm{~m})$ and ${ }^{\mathrm{MEAN}} \Omega_{(35-40 \mathrm{~m})}$ are mean DIC and $\Omega$ values at $35-40 \mathrm{~m}$ deep and ${ }^{\mathrm{MEAN}} \mathrm{DIC}_{(50-70 \mathrm{~m})}$ and ${ }^{\text {MEAN }} \Omega_{(50-70 \mathrm{~m})}$ are mean DIC and $\Omega$ values in the subsurface shelf layer (Table 2). The physico-biogeochemical components that contribute to $\triangle \mathrm{DIC}^{\text {SUBSURFACE }}$ and $\Delta \Omega^{\text {SUBSURFACE }}$, given that air-sea $\mathrm{CO}_{2}$ gas exchange, seaice melt and temperature changes are less important for subsurface waters given the capping of the water column and isolation from the mixed layer above, are expressed by the following equations:

$$
\begin{aligned}
& \Delta \mathrm{DIC}^{\text {SUBSURFACE }}=\delta \mathrm{DIC}_{\mathrm{BIOL}}+\delta \mathrm{DIC}_{\mathrm{NO}_{3}}+\delta \mathrm{DIC}_{\mathrm{VERTDIFF}} \\
& +\delta \mathrm{DIC}_{\text {VERTMIXING }}+\delta \mathrm{DIC}_{\mathrm{ADVECTION}}
\end{aligned}
$$

$$
\begin{aligned}
& \Delta \Omega^{\text {SUBSURFACE }}=\delta \Omega_{\mathrm{BIOL}}+\delta \Omega_{\mathrm{NO}_{3}}+\delta \Omega_{\text {VERTDIFF }} \\
& +\delta \Omega_{\text {VERTMIXING }}+\delta \Omega_{\text {ADVECTION }} .
\end{aligned}
$$

We thus compare and contrast changes in DIC and $\Omega$ in surface and subsurface waters to determine whether potentially corrosive subsurface waters are a signal of the Anthropocene (i.e., ocean acidification) that is compounded by natural physico-biogeochemical processes (Figs. 9, 10). Please note that the contribution due to long-term change in $\Omega$ (or DIC) due to the uptake of anthropogenic $\mathrm{CO}_{2}$ (i.e., $\Sigma \Omega_{\mathrm{CANT}}$ or $\Sigma \mathrm{DIC}_{\mathrm{CANT}}$ ) superimposes its impact on short-term changes irrespective of season, and represents the cumulative impact on $\Omega$ or DIC due to uptake of anthropogenic $\mathrm{CO}_{2}$ up to the present day (see Sect. 4.2.6 for more detail). Many of the terms in Eqs. (3), (4), (5), (8) and (9) will also be relevant to the changes in chemical conditions from summertime to "winter/spring" that complete an annual cycle (Fig. 10).

\subsubsection{Potential physical and biological factors influencing seasonal changes in $\Omega$ in shelf surface waters}

In shelf surface waters of the Chukchi Sea, eastern East Siberian Sea and western Beaufort Sea, we use mean seawater $\mathrm{CO}_{2}$-carbonate chemistry values at different depth intervals (Table 1) to determine the terms in Eqs. (4) and (5) (Table 2). The difference in DIC between winter/early-spring values and summertime surface values was $\sim 180 \mu \mathrm{mol} \mathrm{kg}-1$ (Table 3), and similar to previous observations during SBI (Bates et al., 2005a). However, the salinity-normalized DIC change was only $75.7 \mu \mathrm{mol} \mathrm{kg}^{-1}$ (Tables 2,3 ). Thus, the total change of DIC (i.e., $\triangle \mathrm{DIC}^{\mathrm{SURFACE}}$; salinity-normalized DIC changes) and $\Omega\left(\Delta \Omega^{\text {SURFACE }}\right)$ from winter/early-spring values to summertime values was $-75.7 \mu \mathrm{mol} \mathrm{kg} \mathrm{kg}^{-1}$ and +0.66 for $\Omega$ for the mass balance model, respectively (Table 2).

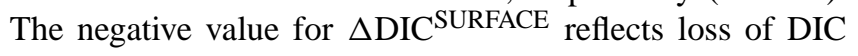
during the winter/early-spring to summertime period (positive value would be an increase in DIC). For the terms in Eq. (4) (and Eq. 9 that are discussed in Sect. 4.2.4; i.e., $\Omega$ terms), we use mean observed DIC, TA, temperature and salinity data to first calculate $\Omega$ using CO2calc (Robbins et al., 2011) and then recalculate $\Omega$ using DIC or another physico-biogeochemical "perturbation" relevant to each term (i.e., $\delta \mathrm{DIC}_{\mathrm{BIOL}}$ ) in Eq. (5) (and Eq. 8 that is discussed in Sect. 4.2.4).

\section{Net community production and nitrate influences on $\Omega$}

The $\delta \mathrm{DIC}_{\mathrm{BIOL}}$ or $\delta \Omega_{\mathrm{BIOL}}$ term is the largest contributor to DIC and $\Omega$ change in shelf surface waters. Marine phytoplankton primary production or net community production $(\mathrm{NCP})$ during the sea-ice-free growing season reduces DIC (i.e., $\delta \mathrm{DIC}_{\mathrm{BIOL}}$ in Eq. 3 ) and increases $\Omega$ values (i.e., $\delta \Omega_{\mathrm{BIOL}}$ in Eq. 4) (Fig. 10a, b). In the Chukchi Sea, very high rates of marine phytoplankton primary production or net community 
Table 3. Physico-biogeochemical contributors to seasonal changes in DIC and $\Omega$ between winter/early-spring conditions and summertime conditions during the 2009-2011 RUSALCA/ICESCAPE expeditions in the western Arctic Ocean. nd = not determined.

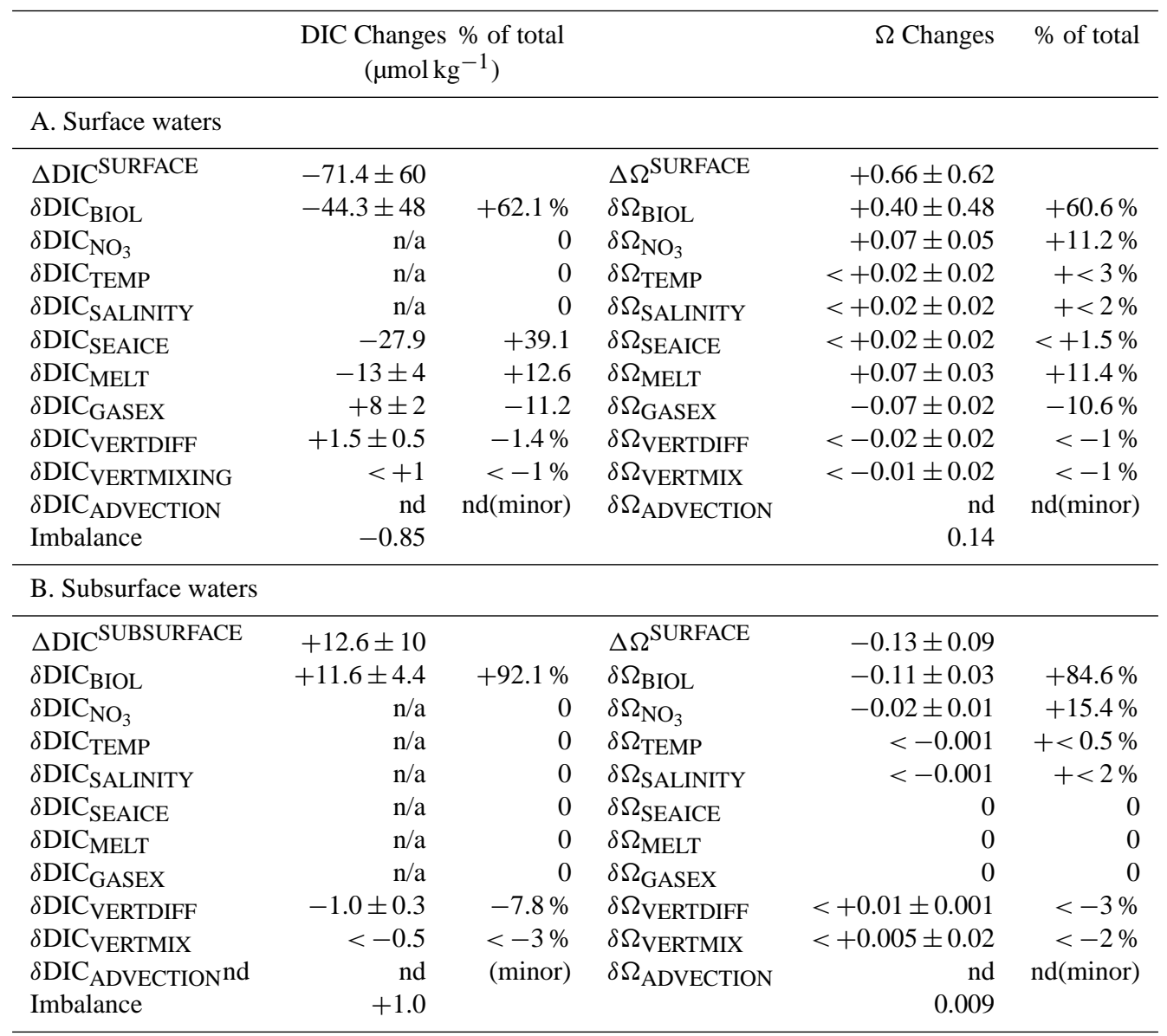

production $\left(0.8-1.2 \mathrm{~g} \mathrm{C} \mathrm{m}^{-2} \mathrm{~d}^{-1}\right.$ and greater than $4 \mathrm{~g} \mathrm{C} \mathrm{m}^{-2}$ $\mathrm{d}^{-1}$; Bates et al., 2005a, and references therein) have been observed in 2002 to 2004 during the SBI project, and similarly during the 2009 to 2011 RUSALCA/ICESCAPE expeditions (Arrigo et al., 2012) especially in the northern areas of the Chukchi Sea shelf. Here, we compare mean remnant winter/early-spring water nitrate and dissolved oxygen concentrations with surface water (i.e., $\triangle \mathrm{NO}_{3}^{\text {SURFACE }}$

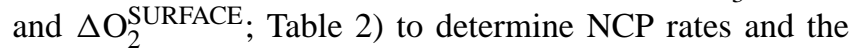
$\delta \mathrm{DIC}_{\mathrm{BIOL}} / \delta \Omega_{\mathrm{BIOL}}$ terms. Using Redfield elemental $\mathrm{C}: \mathrm{N}$ stoichiometry of $6: 1$ and photosynthetic quotient $\mathrm{C}: \mathrm{O}_{2}$ ratio of $1: 1.14$, the mean $\triangle N_{3}^{\text {SURFACE }}$ and $\Delta \mathrm{O}_{2}^{\text {SURFACE }}$ changes of $7.38 \mu \mathrm{mol} \mathrm{kg} \mathrm{kg}^{-1}$ and $49.25 \mu \mathrm{mol} \mathrm{kg} \mathrm{kg}^{-1}$ equate to mean DIC changes of $-44.3 \mu \mathrm{mol} \mathrm{kg}-1$ and $-43.2 \mu \mathrm{mol} \mathrm{kg}-1$, respectively. This DIC change is equivalent to the rate of NCP on the shelf or $\delta \mathrm{DIC}_{\mathrm{BIOL}}$ (Fig. 11a). Assuming an average growing season of 60 days from wintertime to summertime observations, the $\delta \mathrm{DIC}_{\mathrm{BIOL}}$ term is equivalent to an $\mathrm{NCP}$ rate of $\sim 0.3 \mathrm{~g} \mathrm{C} \mathrm{m}^{-2} \mathrm{~d}^{-1}$, which is lower than NCP rates estimated during the SBI project (Bates et al., 2005a). If the phosphate difference between winter/early-spring water and surface summertime water (Table 2), a $\Delta \mathrm{PO}_{4}$ of $0.8 \mu \mathrm{mol} \mathrm{kg}{ }^{-1}$, was used rather than nitrate, then the $\delta \mathrm{DIC}_{\mathrm{BIOL}}$ term would be $84.8 \mu \mathrm{mol} \mathrm{kg} \mathrm{kg}^{-1}$ and the NCP rate estimated at $\sim 0.5 \mathrm{~g} \mathrm{C} \mathrm{m}^{-2}$ $\mathrm{d}^{-1}$. The $\delta \mathrm{DIC}_{\mathrm{BIOL}}$ term is negative, reflecting negative NCP or net autotrophy within the surface waters of the western Arctic shelves (i.e., Chukchi Sea) similar to previous summertime observations (Bates, 2006). The computed $\delta \Omega_{\mathrm{BIOL}}$ term due to $\delta \mathrm{DIC}_{\mathrm{BIOL}}$ is +0.40 and has a standard deviation of \pm 0.48 (Fig. 11b; Table 3 ) that reflects spatio-temporal variability in the rates of NCP on the shelf.

The uptake of nitrate by phytoplankton photosynthesis has an additional impact on $\Omega$ since it increases TA (Brewer and Goldman, 1976) with the net result that $\Omega_{\text {aragonite }}$ (or $\Omega_{\text {calcite }}$ ) increases slightly by $\sim 0.01$ per $1 \mu \mathrm{mol} \mathrm{kg}{ }^{-1}$ of nitrate taken up for photosynthesis. Thus given that the $\Delta \mathrm{NO}_{3}^{\text {SURFACE }}$ value is $7.38 \pm 5.2 \mu \mathrm{mol} \mathrm{kg} \mathrm{g}^{-1}$, the nitrate uptake term increases $\Omega_{\text {aragonite }}$ by $\sim 0.07 \pm 0.05$ (i.e., $\delta \Omega_{\mathrm{NO}_{3}}$; Fig. 11 ; Table 3). Combined, both the $\delta \Omega_{\mathrm{BIOL}}$, which reflects rates of shelf NCP, and $\delta \Omega_{\mathrm{NO}_{3}}$ terms contribute to the impact of biological processes on $\Omega$. 


\section{Temperature and salinity influences on $\Omega$}

Temperature and salinity had minor impact on $\Omega$. For example, seasonal warming of surface waters $\left(\delta \Omega_{\mathrm{TEMP}}\right)$ during sea-ice retreat is computed to increase $\Omega_{\text {aragonite by } \sim 0.01}$ per ${ }^{\circ} \mathrm{C}$. Given that the mean temperature increase exhibited between winter/early-spring and summertime surface water was $2.55 \pm 2.39^{\circ} \mathrm{C}$ (Table 2), we estimate that temperature increased $\Omega$ by $\sim 0.02 \pm 0.02$ (Fig. 11b; Table 3). Compared to remnant winter water, mean surface water salinity was $\sim 6 \%$ lower (Table 2 ), which would increase by $\sim 0.02 \pm 0.02$ (i.e., if surface water was diluted with rainwater with zero TA and DIC end-member; $\delta \Omega_{\text {SALINITY) }}$ if we estimate physicochemical change imparted on $\Omega$ by salinity alone.

\section{Sea-ice melt influences on $\Omega$}

We ascribe the observed changes in salinity to sea-ice melt rather than precipitation or river freshwater input. Mean precipitation of $\sim 6 \mathrm{~cm}$ (recorded at Barrow, Alaska) during the summertime would contribute negligibly to salinity changes $(\sim 0.2 \%$; the dilution of DIC and TA by precipitation has minor impact on $\Omega_{\text {aragonite, i.e., increase of }}$ $\sim 0.06$ per unit change in salinity), while the Chukchi Sea does not receive significant direct river input. During the 2009-2011 expeditions the $6 \%$ reduction of surface salinity likely results primarily from sea-ice melt. Previous reports of $\%$ contribution of sea-ice melt to mixed-layer waters in the Chukchi Sea shelf, determined by $\delta^{18} \mathrm{O}$-salinity relationships (e.g., Cooper et al., 1997), were $<5-10 \%$ in surface water during the 2002-2004 SBI project (Bates, 2006). As described earlier, difference in observed DIC between winter/early-spring values and summertime surface values was $\sim 180 \mu \mathrm{mol} \mathrm{kg}^{-1}$ compared to salinity-normalized DIC change of only $75.7 \mu \mathrm{mol} \mathrm{kg}{ }^{-1}$ (Tables 2,3 ). A $6 \%$ reduction in salinity should reduce DIC and TA by $\sim 120$ and $130 \mu \mathrm{mol} \mathrm{kg}{ }^{-1}$, respectively, which combined with salinitynormalized DIC changes $\left(120+75.7=195.7 \mu \mathrm{mol} \mathrm{kg}^{-1}\right)$ is comparable to the mean observed change in surface DIC of $\sim 180 \mu \mathrm{mol} \mathrm{kg}{ }^{-1}$. However, the mass balance model (Eqs. 1 and 3) uses salinity-normalized DIC so the salinity only influence is explicitly excluded.

Unfortunately, $\delta^{18} \mathrm{O}$-salinity measurements were not conducted during the 2009-2011 RUSALCA/ICESCAPE expeditions, but we can use TA as a proxy tracer for the contribution of sea-ice melt to seawater $\mathrm{CO}_{2}$ carbonate chemistry to the shelf water changes in $\Omega$. Salinity-normalized alkalinity (i.e., nTA) values were $\sim 30 \mu \mathrm{mol}$ higher in surface water compared to below the mixed layer across the shelf, and we use it as a tracer for determining the contribution of sea-ice melt to changes in DIC and $\Omega$ (i.e., $\delta$ DIC MELT $_{1}$ and $\delta \Omega_{\mathrm{MELT}}$ ). Sea-ice melt waters of the western Arctic have DIC and TA values between $\sim 400$ and $800 \mu \mathrm{mol} \mathrm{kg}^{-1}$ (N.R.
Bates, unpublished data from under-ice and above-ice melt ponds in the Chukchi Sea). We thus estimate that dilution of remnant winter water with $6 \%$ sea-ice melt would decrease TA but increase nTA by $\sim 27.9 \mu \mathrm{mol} \mathrm{kg}^{-1}$, similar to the changes observed in surface shelf waters $\left(\delta\right.$ DIC $_{\text {SEAICE}}$; Fig. 11; Table 3). Given that TA : DIC ratios of sea-ice melt water are close to $1: 1$, we compute the mean changes in DIC due to sea-ice melt (i.e., $\delta$ DIC $_{\text {SEAICE }}$ ) was $-28 \mu \mathrm{mol} \mathrm{kg}{ }^{-1}$. Since sea-ice melt also impacts TA, we estimated the net impact on $\Omega$ was minor at $<+0.02\left(\delta \Omega_{\text {SEAICE }}\right.$; Fig. 11 ; Table 3). However, TA and DIC data sampled from under-ice melt ponds during the 2011 ICESCAPE expedition indicate that the TA:DIC ratios were significantly higher than the mixed layer beneath, and than the above-ice melt pond water (Bates et al., 2013). This reduction in DIC relative to TA is most likely due to within-sea-ice primary production during the early growing season. We estimate that the contribution of under-ice sea-ice melt to seawater $\mathrm{CO}_{2}$-carbonate chemistry (i.e., $\delta \mathrm{DIC}_{\mathrm{MELT}}$ ) was equivalent to a loss of $\sim 9$ to $17 \mu \mathrm{mol}^{-1}$ of DIC $\left(13 \pm 0.04 \mu \mathrm{mol} \mathrm{kg}{ }^{-1}\right.$; Fig. $11 \mathrm{a}$; Table 3) or $\sim 0.07 \pm 0.03$ for $\Omega$ (i.e., $\delta \Omega_{\mathrm{MELT}}$; Fig. $11 \mathrm{~b}$; Table 3). It has almost equivalent impact on $\Omega$ as nitrate uptake discussed earlier. Furthermore, reduction in ionic strength of seawater $\left(\right.$ and $\mathrm{Ca}^{2+}$ ) will slightly decrease $\mathrm{CaCO}_{3}$ solubility and $\Omega$ at lower salinities $(<0.01)$ given the range of salinities observed during the RUSALCA/ICESCAPE expeditions (e.g., Butler, 1982).

In contrast to shelf waters, as shown in Fig. 8d, the pres-

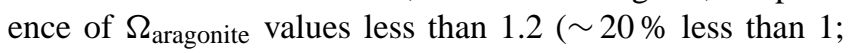
$50-55 \%$ less than 1.2) in the upper $20 \mathrm{~m}$ of the Canada Basin waters likely indicates proportionately greater influence of sea-ice melt waters on seawater $\mathrm{CO}_{2}$-carbonate chemistry (Yamamoto-Kawai et al., 2009; Jutterström and Anderson, 2010) compared to shelf waters.

\section{Gas exchange and mixing influences on $\Omega$}

There are, however, counteracting processes such as gas exchange (i.e., $\delta \Omega_{\mathrm{GASEX}}$ ), vertical diffusion (i.e., $\delta \Omega_{\mathrm{VERTDIFF}}$ ) and mixing (i.e., $\delta \Omega_{\text {VERTMIX) }}$ that can act to decrease $\Omega$ in shelf surface waters (Figs. 9-11). Previous estimates of air-sea $\mathrm{CO}_{2}$ flux on the Chukchi Sea shelf ranged from 10 to $40 \mathrm{mmol} \mathrm{CO}_{2} \mathrm{~m}^{-2} \mathrm{~d}^{-1}$, depending on the magnitude and spatio-temporal variability of the air-sea $p \mathrm{CO}_{2}$ gradient (Bates and Mathis, 2009, and references therein). The flux $(F)$ of $\mathrm{CO}_{2}$ between ocean and atmosphere can be estimated from the difference in $p \mathrm{CO}_{2}$ between air and sea (i.e., $\left.\Delta p \mathrm{CO}_{2}\right)$ and air-sea $\mathrm{CO}_{2}$ gas exchange parameterizations ( $F=\alpha K \Delta p \mathrm{CO}_{2}$; Wanninkhof, 1992, where $\alpha$ is solubility of $\mathrm{CO}_{2}$ in seawater and $K$ is the gas transfer velocity). Given seawater $\mathrm{CO}_{2}$-carbonate chemistry of the winter/early-spring remnant water (Table 2), we estimate this water had a mean seawater $p \mathrm{CO}_{2}$ of $\sim 360 \mu \mathrm{atm}$, about 20-25 uatm lower than the atmospheric $p \mathrm{CO}_{2}$ observed at 
Point Barrow, Alaska (www.esrl.noaa.gov/gmd/obop/brw/). In contrast, surface summertime seawater $p \mathrm{CO}_{2}$ had a mean of $195 \mu \mathrm{atm}$ and a $\Delta p \mathrm{CO}_{2}$ of $\sim 190 \mu \mathrm{atm}$, which indicates that the shelf waters have the strong potential to uptake $\mathrm{CO}_{2}$ from the atmosphere. The mean wind speed in the region (May to August) was $10.5 \pm 2 \mathrm{~m} \mathrm{~s}^{-1}$, and we estimate airsea $\mathrm{CO}_{2}$ fluxes using $\mathrm{CO} 2$ calc (Robbins et al., 2011). We used sea-ice maps produced by NASA to determine the $\%$ of open water during the 2009-2011 expeditions. There was $\sim 100 \%$ sea-ice cover in mid-May with open water present by mid-July on the shelf areas. We thus use a 60-day period (with average $50 \%$ open water) to compute air-sea $\mathrm{CO}_{2}$ flux, which is estimated at $\sim 8.5 \pm 2$ mmoles $\mathrm{CO}_{2} \mathrm{~m}^{-2} \mathrm{~d}^{-1}$ at the beginning of sea-ice melt in mid-May to a mean of $12.5 \pm 3$ by the beginning of August. Assuming that the $\mathrm{CO}_{2}$ influx is integrated over the mixed layer (i.e., $30 \mathrm{~m}$ deep), we estimate that gas exchange increased DIC by $\sim 6$ to $10.5 \mu \mathrm{mol} \mathrm{kg}^{-1}$ (i.e., $\delta \mathrm{DIC}_{\mathrm{GASEX}}$, Fig. $11 \mathrm{a}$ ) and $\Omega$ by $\sim 0.05-0.09$ (i.e., $\delta \Omega_{\text {GASEX }}=0.07 \pm 0.02$; Fig. $11 \mathrm{~b}$; Table 3). Please note that these terms reflect mean values and they do not reflect the spatio-temporal variability of $\Delta p \mathrm{CO}_{2}$ and $F$. The uncertainty of the $\delta \Omega_{\mathrm{GASEX}}$ term is likely to be higher than 0.02 , but as with the $\delta \Omega_{\mathrm{BIOL}}$ term, interannual variability is likely to impart greater variability in the $\delta \Omega_{\text {GASEX }}$ term.

\section{Vertical mixing and diffusion influences on $\Omega$}

Vertical mixing (i.e., $\delta$ DIC $\mathrm{VERTMIXING}_{\mathrm{V}} / \delta \Omega_{\mathrm{VERTMIXING}}$ ) or diffusion of $\mathrm{CO}_{2}$ (i.e., $\delta$ DIC VERTDIFF $/ \delta \Omega_{\mathrm{VERTDIFF}}$ ) into surface waters could act to reduce $\Omega_{\text {aragonite }}$ of surface waters, but, again, strong stratification induced by freshening, sea-ice melt and warming would likely suppress any entrainment of high- $p \mathrm{CO}_{2}$, low- $\mathrm{pH} / \Omega$ subsurface waters into the surface layer (Fig. 10). Vertical diffusivity flux of $\mathrm{CO}_{2}$ (i.e., $\delta$ DIC VERTDIFF $/ \delta \Omega_{\text {VERTDIFF) was estimated as the prod- }}$ uct of the vertical diffusion coefficient $\left(K_{v}\right)$, DIC gradient $(\delta \mathrm{DIC} / \delta \mathrm{Z})$ below the mixed layer (i.e., vertical gradient in DIC below $30 \mathrm{~m}$ ), and seawater density (Denman and Gargett, 1983) using an average $K_{v}$ of $30 \mathrm{~cm}^{2} \mathrm{~s}^{-1}$ (Bates et al., 2005a). We estimate that vertical diffusion across the base of the mixed layer increased DIC by $<1-2 \mu \mathrm{mol} \mathrm{kg}^{-1}$ and $\Omega$ by $<0.02$ (Table 3 ). As shown in Fig. 10, vertical mixing could also contribute DIC to surface waters, thereby lowering $\Omega$. This term is difficult to estimate since there are insufficient data on mixed-layer changes during the 2009-2011 RUSALCA/ICESCAPE expeditions. However, it is likely that this term is minor given that the summertime is a period of shoaling/detrainment and that the considerable density difference between surface and subsurface waters should have suppressed mixing on the shelf. Rather, cooling and deeper convective mixing beyond $25-30 \mathrm{~m}$ and homogenization of shelf waters occur later in the late-September to November period during rapid winter freeze-up, and sea-ice formation and brine rejection.

\section{Other potential influences on $\Omega$}

Other potential physical and biological factors have a minor or undetermined impact on $\Omega$. As shown in Fig. 7, calcification or dissolution of $\mathrm{CaCO}_{3}$ in surface waters was not likely to contribute to changes in $\Omega$ given that pelagic calcifiers such as coccolithophorids (and $\mathrm{CaCO}_{3}$ lith production) were not observed in the western Arctic during the ICESCAPE cruises (Arrigo et al., 2012; W. M. Balch, personal communication, 2012). Pelagic pteropods, with aragonitic shells, are present in the western Arctic, but it is not certain if they have sufficient biomass and calcification rates to influence seawater $\mathrm{CO}_{2}$-carbonate chemistry. The shelly epi- and infauna, including benthic foraminifera of the Chukchi Sea shelf benthos, clearly produce $\mathrm{CaCO}_{3}$, but given summertime strong stratification, we assume that benthic calcification has minor impact on surface $\Omega$ due to suppression of mixing $\Omega$ (Fig. 10a).

\section{Imbalance of mean surface $\boldsymbol{\Omega}$}

As shown in Fig. 11, our best estimates of terms in Eqs. (3) and (4) explain most of the winter/early-spring to summertime changes in seawater $\mathrm{CO}_{2}$-carbonate chemistry. The major terms that contribute to $\triangle \mathrm{DIC} \mathrm{SURFACE}^{\mathrm{S}}$ and $\Delta \Omega^{\mathrm{SURFACE}}$ are due to NCP (i.e., $\delta \Omega_{\mathrm{BIOL}}$ ), nitrate uptake (i.e., $\delta \Omega_{\mathrm{BIOL}}$ ), sea-ice melt contributions (i.e., $\delta \Omega_{\mathrm{MELT}}$ ), and gas exchange (i.e., $\left.\delta \Omega_{\mathrm{GASEX}}\right)$. For DIC, no imbalance in the terms was found, but there was an imbalance for $\Omega$ of 0.18 (Fig. 11; Table 3). The largest uncertainty appears associated with determination of $\mathrm{NCP}$ rate and hence determination of $\delta \mathrm{DIC}_{\mathrm{BIOL}} / \delta \Omega_{\mathrm{BIOL}}$ terms. Year-to-year variability in $\mathrm{NCP}$ would thus likely impart considerable variability in the actual $\delta \Omega_{\mathrm{BIOL}}$ term, but here we view the $\delta \Omega_{\mathrm{BIOL}}$ term in the mean or average sense. If we had used phosphate rather than nitrate to determine $\mathrm{NCP}$, then the $\delta \mathrm{DIC}_{\mathrm{BIOL}} / \delta \Omega_{\mathrm{BIOL}}$ term would have been much higher at $84.8 \mu \mathrm{mol} \mathrm{kg} \mathrm{k}^{-1}$ or +0.71 , respectively, causing a much larger imbalance in terms of DIC and $\Omega$. During the SBI project, a transition from high $\mathrm{C}: \mathrm{N}$ ratios to lower $\mathrm{C}: \mathrm{N}$ ratios was observed in suspended particulate organic matter (Bates et al., 2005b) that suggests that the shelf waters were producing N-poor organic matter by summertime. Thus the $\triangle \mathrm{NO}_{3}^{\text {SURFACE }}$ term used to determine NCP and $\delta \mathrm{DIC}_{\mathrm{BIOL}}$ may underestimate both.

The air-sea $\mathrm{CO}_{2}$ flux rates computed here were on the lower end of previous ranges reported for the Chukchi Sea (up to $40 \mathrm{mmol} \mathrm{CO}_{2} \mathrm{~m}^{-2} \mathrm{~d}^{-1}$; Bates and Mathis, 2009). Using the higher rates of gas exchange reported (assuming that the summertime observations are at the mid-point of the seasonal $\mathrm{CO}_{2}$ influx during open water), the $\delta \Omega_{\mathrm{GASEX}}$ term may be higher by $\sim 0.06$ to 0.1 . 
The contribution of other water masses with different seawater $\mathrm{CO}_{2}$-carbonate chemistry properties (i.e., $\left.\delta \mathrm{DIC}_{\mathrm{ADVECTION}} / \delta \Omega_{\mathrm{ADVECTION}}\right)$ is an undetermined contributor to the mass balance model assessment. The inflow of Alaskan Coastal Current (ACC) water appears to bring high- $\Omega$ water through Bering Strait into the Chukchi Sea ( $\Omega$ values of 2.2; Table 2 ), while inflow of Siberian Coastal Current (SCC) water likely brings low- $\Omega$ waters due to respiration and remineralization on the East Siberian Sea shelf (e.g., Semiletov et al., 2007; Anderson et al., 2010). However, as estimated in Sect. 3.1, the residence time of water on the Chukchi Sea shelf is $\sim 6$ months, and given the rapid (i.e., $<2$ months) sea-ice retreat and biological responses (i.e., NCP) on the shelf, inflow of both ACC and SCC is likely to impact the southern part of the Chukchi Sea rather than the entire shelf. This advection term may contribute to the imbalance of the mass balance (i.e., Table 3), but we cannot evaluate its quantitative importance here (including uncertainty that advection may also contribute to changes in nitrate that were used to estimate the $\delta \mathrm{DIC}$ BIOL $/ \delta \Omega_{\mathrm{BIOL}} / \delta \Omega_{\mathrm{NO}_{3}}$ terms).

\subsubsection{Potential physical and biological factors influenc- ing seasonal changes in $\Omega$ in subsurface waters}

During the SBI expedition, subsurface $\Omega(50-100 \mathrm{~m})$ decreased in 2002 and 2004 by 0.18 and 0.05 , respectively, compared to surface waters (Bates et al., 2009). In comparison, the $\triangle$ DIC ${ }^{\text {SUBSURFACE }}$ and $\Delta \Omega^{\text {SUBSURFACE }}$ of subsurface waters (Eqs. 6 and 7) below $50 \mathrm{~m}$ deep increased by $12.6 \mu \mathrm{mol} \mathrm{kg} \mathrm{g}^{-1}$ and decreased by 0.13 , respectively, during the 2009-2011 RUSALCA-ICESCAPE expedition compared to winter/early-spring water (Fig. 9b, Table 3). The increase in subsurface DIC and reduction in $\Omega$ appears primarily due to the $\delta \mathrm{DIC}_{\mathrm{BIOL}}\left(+11.6 \pm 4.4 \mu \mathrm{mol} \mathrm{kg}{ }^{-1}\right)$ and $\delta \Omega_{\mathrm{BIOL}}(-0.11 \pm 0.03)$ terms. These terms were computed from the change in nitrate concentration between winter/early-spring water and subsurface waters of $\sim 1.94 \pm 1.55 \mu \mathrm{mol} \mathrm{kg}^{-1}$. The $\delta \Omega_{\mathrm{BIOL}}$ term is positive, which reflects a positive NCP value or net heterotrophy in the subsurface waters of the shelf. There was also minor contributions from vertical diffusion and mixing (Table 3), but negligible/zero contributions from changes in temperature or contributions from sea-ice, sea-ice melt or gas exchange. As with surface waters, there is a small imbalance in the terms, with the largest uncertainty related to the standard deviation of the mean $\delta \mathrm{DIC}_{\mathrm{BIOL}}$ and $\delta \Omega_{\mathrm{BIOL}}$ terms. In summary, the decrease in subsurface $\Omega$ appears related primarily to production of $\mathrm{CO}_{2}$ and DIC. This must result from a combination of remineralization of sinking organic matter back to $\mathrm{CO}_{2}$, pelagic community respiration and benthic community respiration.

\subsubsection{Imbalance in the $\delta \mathrm{DIC} \mathrm{BIOL}_{\mathrm{L}}$ and $\delta \Omega_{\mathrm{BIOL}}$ terms of surface and subsurface waters and winter resetting}

The mass balance model also suggests that there is an imbalance of the $\delta \mathrm{DIC}_{\mathrm{BIOL}}$ and $\delta \Omega_{\mathrm{BIOL}}$ term for surface and subsurface waters of the western Arctic (i.e., Table 3). The differences between surface $(0-20 \mathrm{~m})$ and subsurface $(50-80 \mathrm{~m})$ $\delta \mathrm{DIC}_{\mathrm{BIOL}}$ and $\delta \Omega_{\mathrm{BIOL}}$ terms were $32.7 \mu \mathrm{mol} \mathrm{kg}{ }^{-1}$ and 0.29 , respectively. This imbalance is likely driven by unquantified terms such as the slow release of $\mathrm{CO}_{2}$ from shelf sediments (due to remineralization of sedimentary organic carbon and benthic ecosystem respiration; e.g., Grebmeier et al., 2008) and offshelf horizontal export of organic carbon (Bates et al., $2005 \mathrm{~b}$ ). The former process is likely to reduce $\Omega$ in bottom waters during the wintertime sea-ice covered period when the water column on the shelf is well mixed. For the latter process, previous studies have shown large plumes of suspended particulate organic matter being transported off the Chukchi Sea shelf into the halocline of the Canada Basin (e.g., Bates et al., 2005b). The implication of these observations is that the $\Omega$ values of halocline waters in the Canada Basin are reduced from remineralization of shelf-derived, allochthonous organic carbon.

The proceeding mass balance model for surface and subsurface waters of the western Arctic shelves (i.e. primarily Chukchi Sea) reflects seawater $\mathrm{CO}_{2}$-carbonate chemistry changes associated with the winter-to-summertime seasonal transition. While we cannot explicitly define terms for the subsequent season (i.e., summer to winter), it is likely that strong mixing and water column homogenization during the winter freeze-up and sea-ice advance (in October and November) blends late summer surface and subsurface physico-biogeochemical conditions. Winter freeze-up thus likely "resets" seasonally imparted changes in $\mathrm{pH}$ and $\Omega$ to "winter" conditions during the sea-ice cover until the next spring/summertime sea-ice retreat (as conceptually shown in Fig. 10).

\subsubsection{The contribution of ocean acidification $\left(\delta \Omega_{\mathrm{OA}}\right)$ to $\Omega$ changes in the western Arctic}

We estimate the present-day contribution of ocean acidification due to uptake of anthropogenic $\mathrm{CO}_{2}$ (i.e., $\Sigma \Omega_{\mathrm{CANT}}$ ) as follows. Recent estimates of the global ocean inventory of anthropogenic $\mathrm{CO}_{2}$ have been reported to range from $\sim 120$ to $160 \mathrm{Pg} \mathrm{C}\left(\mathrm{Pg}=10^{15} \mathrm{~g} \mathrm{C}\right.$; Sabine et al., 2004; Khatiwala et al., 2009). In the Arctic Ocean, the inventory of anthropogenic $\mathrm{CO}_{2}$ has been estimated at approximately 2.5 to $3.3 \mathrm{Pg} \mathrm{C}$, or about $2 \%$ of the global ocean inventory (Tanhua et al., 2009). Pacific Ocean water entering the western Arctic has a reported anthropogenic $\mathrm{CO}_{2}$ content of 30$40 \mu \mathrm{mol} \mathrm{kg}{ }^{-1}$ of DIC (Sabine et al., 2004), while the Tanhua et al. (2009) estimate suggests a range of $\sim 20-50 \mu \mathrm{mol} \mathrm{kg}^{-1}$ for anthropogenic $\mathrm{CO}_{2}$ content in upper waters of the Arctic 
(depending on water depth, residence time and Atlantic versus Pacific Ocean source of waters entering the Arctic region). Given the relatively short residence time of shelf waters in the western Arctic ( $\sim 6$ months; Sect. 3.1$)$, we assume that the anthropogenic $\mathrm{CO}_{2}$ content of western Arctic shelf water reflects conditions in the North Pacific Ocean. Thus, we estimate that the anthropogenic $\mathrm{CO}_{2}$ content of the upper ocean of the western Arctic shelf waters is approximately $30-40 \mu \mathrm{mol} \mathrm{kg}^{-1}$ of DIC. Stated another way, the mean DIC content of polar surface water is estimated to be $30-40 \mu \mathrm{mol} \mathrm{kg}^{-1}$ greater at present compared to preindustrial times, with the consequence of reducing $\mathrm{pH}$ and $\Omega$. Given salinity, temperature, DIC and TA values for surface to subsurface waters of the western Arctic shelves observed during summertime of 2009 to 2011, we estimate that ocean acidification due to anthropogenic $\mathrm{CO}_{2}$ uptake has reduced $\Omega$ values by $\sim 0.4$ to 0.6 for $\Omega_{\text {calcite }}$ and $\sim 0.3$ to 0.4 for $\Omega_{\text {aragonite }}$ since pre-industrial times up to the present day. Using the range of observed seawater $\mathrm{CO}_{2}$-carbonate chemistry, $40 \mu \mathrm{mol} \mathrm{kg}{ }^{-1}$ of anthropogenic $\mathrm{CO}_{2}$ is computed to decrease

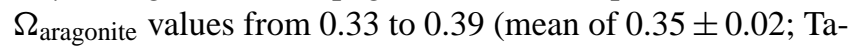
ble 3). The uncertainty in the $\delta \Omega_{\text {CANT }}$ term is likely to be $\sim 0.08$ for $\Omega_{\text {calcite }}$ and $\sim 0.05$ for $\Omega_{\text {aragonite }}$ given the uncertainty in North Pacific Ocean anthropogenic $\mathrm{CO}_{2}$ content.

A schematic seasonal time series for $\Omega_{\text {aragonite }}$ is shown with $\delta \Omega_{\text {CANT }}$ denoted by the dashed yellow line for both surface and subsurface waters (Fig. 10b, c; a similar time series for $\Omega_{\text {calcite }}$ is not shown but would be scaled by approximately $150 \%$ ). Superimposed on the long-term cumulative changes due to ocean acidification are changes in $\Omega$ imparted by seasonal processes (e.g., $\delta \Omega_{\mathrm{BIOL}}, \delta \Omega_{\mathrm{GASEX}}$, and $\delta \Omega_{\mathrm{TEMP}}$ ) discussed in Sects. 4.2.3 and 4.2.4 (Fig. 10). A final caveat is that while the long-term impact of ocean acidification can be shown in Fig. 10, long-term changes in other factors such as salinity (changes in hydrology/freshwater input) and temperature (warming in the Arctic) are not shown but are likely to have longer-term effects on $\Omega$.

Compared to pre-industrial times, the mean $\Omega$ values of bottom waters on the shelf appear to be $\sim 0.35$ lower at the present time, with subsurface processes further reducing $\Omega$ by $\sim 0.13$ during the summertime sea-ice retreat. As described earlier in Sect. 3.5, nearly $70 \%$ of bottom-water samples deeper than $20 \mathrm{~m}$ had $\Omega_{\text {aragonite }}$ of $<1.2$ (mostly East Siberian Sea and the majority of Chukchi Sea), with $40 \%$ of samples having $\Omega_{\text {aragonite }}$ values of $<1.0$ (Fig. 8). If the contribution of $\delta \Omega_{\text {CANT }}$ is removed, it is likely that shelf bottom waters were not undersaturated with respect to aragonite during pre-industrial times, with perhaps only $10-30 \%$ of bottom waters having $\Omega_{\text {aragonite }}$ values less than 1.5. Thus, it appears highly likely that the presence of corrosive waters on the western Arctic shelves is a recent phenomenon, a signal of the Anthropocene. Furthermore, on seasonal timescales, it seems that, while uptake of anthropogenic $\mathrm{CO}_{2}$ and ocean acidification has cumulatively reduced subsurface water $\Omega$ values close to a value of one, it is biologically mediated suppression of $\Omega$ values that tips the balance and reduces $\Omega$ values below a value of one (Fig. 7b). Such seasonal transitions in $\Omega$ that are compounded by natural biological processes have also been shown to occur in the Bering Sea shelf (Mathis et al., 2009, 2011a, b) and in the East Siberian Sea (Anderson et al., 2010).

\subsubsection{Is there any change in the distribution of low- $\Omega$ bottom water in the western Arctic?}

The 2009 to 2011 RUSALCA/ICESCAPE data revealed large areas of $\Omega_{\text {aragonite }}$ undersaturation across the Chukchi Sea shelf (Fig. 5 shows that $\sim 70 \%$ of bottom water had $\Omega_{\text {aragonite }}$ values less than 1.2). The summer $\Omega_{\text {aragonite }}$ values decreased to levels lower than observed in previous years during the SBI project from 2002 to 2004 (Bates et al., 2009). In the 2002-2004 period, undersaturated bottom waters were only observed on the northern slope of the Chukchi Sea rather than across the entire shelf as observed more recently. Our observations from 2009 to 2011 suggest that low$\Omega$ bottom water has expanded across the shelves of the western Arctic Ocean. Arrigo et al. (2008) have shown significant increases in rates of summertime phytoplankton primary production (and a longer growing season) in surface waters across the Arctic over the last two decades. Model studies also suggest that coastal shelf phytoplankton primary production has increased over the last few decades (e.g., Manizza et al., 2013). The ICESCAPE expeditions in 2010 and 2011 found extensive blooms of phytoplankton under the sea ice of the central Chukchi Sea (Arrigo et al., 2012), and some of the lowest seawater values of seawater $p \mathrm{CO}_{2}$ ever observed in the global ocean (i.e., $<100 \mu \mathrm{atm}$ ) have been measured in this area (e.g., Bates et al., 2011). The implications of these studies are that if rates of primary production are higher in the western Arctic Ocean compared to other regions of the Arctic, then surface water enhancement of $\Omega$ is likely as well as concomitant reduction of $\Omega$ values in bottom waters present on the shelf. This presumably could be linked to increased vertical export of organic carbon and subsequent benthic respiration and remineralization. Potentially counteracting this phenomena is the likelihood that a longer growing season, lower surface seawater $p \mathrm{CO}_{2}$ and expanded areas of seasonally sea-ice-free areas will enhance the uptake of $\mathrm{CO}_{2}$ from the atmosphere through air-sea $\mathrm{CO}_{2}$ gas exchange.

In the central basin of the Arctic Ocean, increases in surface seawater $p \mathrm{CO}_{2}$ - and presumably reduction in $\Omega$ - due to enhanced air-sea $\mathrm{CO}_{2}$ gas exchange since the major seaice loss event in 2007 have been determined to have reduced the sink of $\mathrm{CO}_{2}$ into surface waters over the last few years (Cai et al., 2010, 2013).

It is evident that the geographic distribution and seasonal timing of seawater $\mathrm{CO}_{2}$-carbonate chemistry, $\mathrm{pH}$ and $\Omega$ variability is rapidly changing in a transitioning Arctic Ocean. Ocean time-series stations show that the DIC content of surface waters is increasing at a rate of $\sim 0.7$ to 
$1.0 \mu \mathrm{mol} \mathrm{kg}{ }^{-1}$ year $^{-1}$ (e.g., Bates et al., 2012; Tanhua et al., 2013). Given our observations that $70 \%$ of shelf bottom waters had $\Omega_{\text {aragonite values }}<1.2$, it is likely that at least $70 \%$ of bottom waters will be undersaturated with respect to aragonite (i.e., $\Omega_{\text {aragonite }}<1.0$ ) for a few months each year within 20 to 30 years, with the caveat that other synergistic environmental impacts in the Arctic may enhance the mitigation of this $\Omega$ reduction.

\subsection{Potential impact on marine ecosystems}

Considering the fact that $\Omega_{\text {aragonite }}$ and $\Omega_{\text {calcite }}$ are generally lower in the high-latitude regions (Doney et al., 2009), gradual ocean acidification in the future may have an earlier impact on polar and subpolar benthic calcifying organisms compared to temperate and tropical species (e.g., Doney et al., 2009; Bates et al., 2009; Mathis et al., 2011a). The seasonal presence of potentially corrosive bottom waters for $\mathrm{CaCO}_{3}$ may have a variety of direct impacts on juvenile to adult benthic calcifying organisms, and their associated ecosystems. For example, $\mathrm{CaCO}_{3}$ undersaturation can be harmful especially in early development stages of calcifying organisms (Lischka et al., 2011). Rapid changes in seawater $\mathrm{CO}_{2}$-carbonate chemistry of the Arctic Ocean might cause a decrease in diversity of calcifying organisms (both benthic and planktonic), with consequences for trophic flow/ecosystem structure (Walther, 2010). The most recent study on mineralogy of skeletons of bimineralic calcifiers exposed to seawater high- $\mathrm{CO}_{2}$ conditions showed increases of the calcite-to-aragonite ratio (Ries, 2011), favoring calcitic organisms. Experimental calcification studies on Arctic Ocean pteropods (which secrete aragonite shells) showed a $28 \%$ decrease in calcification projected for 2100 low-pH conditions (Comeau et al., 2009). The increased solubility of aragonite compared to calcite makes this form of $\mathrm{CaCO}_{3}$ mineral more vulnerable to dissolution in waters with low $\mathrm{pH}$ values $(<8.0)$ and lower $\Omega$ conditions (i.e., $<1)$.

As described in Sect. 3.5 and shown in Fig. 8, the deeper benthos $(<20 \mathrm{~m}$ deep) appears to be more vulnerable to the impact of reduced $\Omega$ brought about by ocean acidification and summertime suppression of $\Omega$. In contrast, the shallow benthos of the western Arctic shelves may be more resilient, with summertime enhancement of $\Omega$ offsetting long-term $\Omega$ reduction by ocean acidification. Given the relatively high $\Omega$ of shallow water ( $>2.0$ ) on the western Arctic shelves, it may be more than a century before the shallow benthos experiences undersaturated water conditions. Over the next few decades, a pronounced benthic community zonation with respect to depth and $\Omega$ conditions is likely, as is deeper parts of the Chukchi Sea shelf exhibiting reduced calcification (and presence of shelly fauna) due to unfavorable seawater chemical conditions. Given that the seawater $\mathrm{CO}_{2}$-carbonate chemistry of the Arctic Ocean is controlled by complex physical and biological processes that are vulnerable to future environmental change (Kaltin and Anderson, 2005), quantifying the responses of calcifying organisms to ocean acidification and seasonally changing $\Omega_{\text {aragonite }}$ is of great importance for the future (Orr et al., 2005; Walther et al., 2009; Comeau et al., 2009; Smith, 2009; Lischka et al., 2011).

\section{Conclusions}

Previous models predict that undersaturation with respect to aragonite will occur in the polar mixed layer of the Arctic by 2016, with the polar shelves transitioning later this century (Steinacher et al., 2009). Observations have shown previously that the polar mixed layer in the Canada Basin (Yamamoto-Kawai et al., 2009) and small areas of the Chukchi Sea shelf (Bates et al., 2009) already exhibit $\Omega$ values less than one. In this study, we find that $\sim 40 \%$ of bottom-water sampled had $\Omega_{\text {aragonite values less than } 1.0 \text { and }}$ $\sim 70 \%$ less than 1.2. Thus large areas of the shelf in the western Arctic are seasonally exposed to bottom waters that are undersaturated with respect to $\mathrm{CaCO}_{3}$ minerals and thus potentially corrosive for biogenic or sedimentary $\mathrm{CaCO}_{3}$. Our results suggest that the area of undersaturation for aragonite and even calcite has expanded to most of the western Arctic shelf over the last decade, but sustained time-series observations are needed to confirm this suggestion.

The potential causes for these changes in seawater $\mathrm{CO}_{2}$ carbonate chemistry in the western Arctic relate to ocean acidification and seasonal biological/physical processes in the region. Ocean acidification due to anthropogenic $\mathrm{CO}_{2}$ uptake is estimated to have reduced $\Omega$ values by $\sim 0.4$ to 0.6 for $\Omega_{\text {calcite }}$ and $\sim 0.3$ to 0.4 for $\Omega_{\text {aragonite }}$ since pre-industrial times. However, superimposed on the ocean acidification influence on $\Omega$ are seasonal physico-biogeochemical processes that drive $\Omega$ values in different directions for surface and subsurface waters. As such, these processes mitigate and enhance the impact of ocean acidification seasonally in surface and subsurface waters, respectively. Future changes in $\Omega$ values on the western Arctic shelves appear unpredictable due to uncertainties about the extent of sea-ice loss, warming, changes in marine phytoplankton production and airsea $\mathrm{CO}_{2}$ gas exchange in the region. Expansion of the areas that are sea ice free and have increased surface water warming and an increased growing season may synergistically facilitate future increases in marine phytoplankton primary production/NCP that in turn could exacerbate subsurface suppression of $\Omega$ values due to increased vertical export of organic carbon. Counteracting this may be increased air-sea $\mathrm{CO}_{2}$ gas exchange in the region (due to longer seaice-free periods and increased marine phytoplankton primary production/NCP) that would act to increase $\Omega$ values. Such predictions are difficult to make given that air-sea $\mathrm{CO}_{2}$ gas exchange rates appear to be rapidly changing in the Arctic Ocean (Bates and Mathis 2009). The deep Arctic Ocean basins (Canada and Eurasian basins) and surrounding shallow coastal seas (e.g., Barents, Laptev, Kara, East Siberian, 
Chukchi, and Beaufort seas, and Canadian Archipelago) constitute only $\sim 4 \%$ of global ocean area (Pipko et al., 2011). In the last couple of decades, the summertime retreat of summer sea ice from the Arctic polar shelves due to enhanced melting has exposed surface waters to the atmosphere and allowed the shallow coastal seas of the Arctic Ocean such as the Chukchi and Barents Sea (and Bering Sea) to become significant sinks for atmospheric $\mathrm{CO}_{2}$ (Murata and Takizawa, 2003; Bates, 2006; Chen and Borges, 2009). Such changes may have temporarily increased the ocean uptake of $\mathrm{CO}_{2}$ into the Arctic (Bates et al., 2006) such that the Arctic Ocean now contributes approximately 5-14\% of the annual global $\mathrm{CO}_{2}$ uptake (Bates and Mathis, 2009) and as a consequence suppressed $\Omega$ values on the shelves. However, since the major sea-ice loss event in 2007, observations indicate that the Arctic may have transitioned back to a smaller sink for $\mathrm{CO}_{2}$ (Cai et al., 2010, 2012) with potentially less impact on $\Omega$, illustrating the dynamic and rapidly changing nature of the Arctic environment.

In this study, we have not addressed any observed impact on benthic organisms or ecosystems, but it is clear that the combination of ocean acidification and seasonal physicobiogeochemical processes combine to seasonally produce conditions that are potentially unfavorable for calcifying organisms and merit future monitoring of the western Arctic shelves.

Acknowledgements. The authors wish to thank the crews of the research vessels that took part in obtaining the data, and all the technicians that participated in collecting the samples. We thank Deborah Ianson and four anonymous reviewers for their insightful and constructive comments. Part of this work was undertaken as a studentship to Monika Orchowska supported by the Nippon Foundation and Partnership for Observation of Global Ocean at the Bermuda Institute of Ocean Sciences. The following US federal agencies are thanked for their support through the following grants: NASA-NNX10AG36G; NOAA-NA080AR4310605, and NSF OPP-1107457.

Edited by: K. Fennel

\section{References}

ACIA, Arctic Climate Impact Assessment: Cambridge University Press, 1042 pp., USA, 2005.

Anderson, L. G., Dyrssen, D., and Jones, E. P., An assessment of the transport of atmospheric $\mathrm{CO}_{2}$ into the Arctic Ocean, J. Geophys. Res., 95, 1703-1711, 1990.

Anderson, L. G., Jutterstrom, S., Hjalmarsson, S. H., Wahlstrom, I., and Semiletov, I. P.: Out-gassing of $\mathrm{CO}_{2}$ from Siberian Shelf seas by terrestrial organic matter decomposition, Geophys. Res. Lett., 36, L20601, doi:10.1029/2009GL040046, 2009.

Anderson, L.G., Tanhua, T., Bjork, G., Hjalmarsson, S.H., Jones, E.P., Anderson, L. G., Tanhua, T., Bjork, G., Hjalmarsson, S.H., Jones, E.P., Jutterstrom, S., Rudels, B., Swift, J. H. and Wahlstrom, I.: Arctic ocean shelf-basin interaction: An active continental shelf $\mathrm{CO}_{2}$ pump and its impact on the degree of calcium carbonate solubility, Deep-Sea Res. Pt. I, 57, 869-879, doi:10.1016/j.dsr.2010.03.012, 2010.

Anderson, L. G., Björk, G., Jutterström, S., Pipko, I., Shakhova, N., Semiletov, I., and Wåhlström, I.: East Siberian Sea, an Arctic region of very high biogeochemical activity, Biogeosciences, 8 , 1745-1754, doi:10.5194/bg-8-1745-2011, 2011.

Andersson, A. J., Mackenzie, F. T., and Bates, N. R.: Life on a margin: implication of ocean acidification on Mg-calcite, high latitude and cold-water marine calcifiers, Mar. Ecol.-Prog. Ser., 373, 265-273, 2010.

Andersson, A. J., Mackenzie, F. T., and Gattuso, J.-P.: Effects of ocean acidification on benthic processes, organisms, and ecosystems, in: Ocean Acidification, edited by: Gattuso, J.-P. and Hansson, L., Oxford University Press, New York, 122-153, 2011.

Arrigo, K. R., van Dijken, G., and Pabi, S.: Impact of a shrinking Arctic ice cover on marine primary production, Geophys. Res. Lett., 35, L19603, doi:10.1029/2008GL035028, 2008.

Arrigo, K. J., Perovich, D. K., Pickart, R. S., Brown, Z. W., van Dijken, G. L., Lowry, K. E., Mills, M. M., Palmer, M. A., Balch, W. M., Bates, N. R., Benitez-Nelson, C., Brownlee, E., Ehn, J. K., Frey, K. E., Garley, R., Laney, S. R. Mathis, J. T., Matsuoko, A., Mitchell, B. G., Moore, G. W. K., Ortega-Retuerta, E., Plasshenski, C. M., Reynolds, R. A., and Swift, J. H.: Massive phytoplankton blooms under Arctic sea-ice, Science, 336, 1408-1409, doi:10.1126/science.1215065, 2012.

Azetsu-Scott, K., Clarke, A., Falkner, K., Hamilton, J., Jones, E.P., Lee, C., Petrie, B., Prinsenberg, S., Starr, M., and, Yeats, P.: Calcium carbonate saturation states in the waters of the Canadian Arctic Archipelago and the Labrador Sea, J. Geophys. Res.Oceans, 115, C11021, doi:10.1029/2009JC005917, 2010.

Bates, N. R.: Air-sea carbon dioxide fluxes and the continental shelf pump of carbon in the Chukchi Sea adjacent to the Arctic Ocean, J. Geophys. Res.-Oceans, 111, C10013, doi:10.129/2005JC003083, 2006.

Bates, N. R. and Mathis, J. T.: The Arctic Ocean marine carbon cycle: evaluation of air-sea $\mathrm{CO}_{2}$ exchanges, ocean acidification impacts and potential feedbacks, Biogeosciences, 6, 2433-2459, doi:10.5194/bg-6-2433-2009, 2009.

Bates, N. R. and Peters, A. J.: The contribution of atmospheric acid deposition to ocean acidification in the subtropical North Atlantic Ocean, Mar. Chem., 107, 547-558, doi:10.1016/j.marchem.2007.08.002, 2007.

Bates, N. R., Michaels, A. F., and Knap, A. H.: Seasonal and interannual variability of oceanic carbon dioxide species at the US JGOFS Bermuda Atlantic Time-series Study (BATS) site, DeepSea Res. Pt. II, 43, 347-383, doi:10.1016/0967-0645(95)000933, Corrigendum, 43, 1435-1435, 1996.

Bates, N. R., Best, M. H. P., and Hansell, D. A.: Spatio-temporal distribution of dissolved inorganic carbon and net community production in the Chukchi and Beaufort Seas, Deep-Sea Res. Pt. II, 52, 3303-3323, doi:10.1016/j.dsr2.2005.10.005, 2005a.

Bates, N. R., Hansell, D. A., Moran, S. B., and Codispoti, L. A.: Seasonal and spatial distributions of particulate organic matter (POM) in the Chukchi and Beaufort Seas, Deep-Sea Res. Pt. II, 52, 3324-3343, doi:10.1016/j.dsr2.2005.10.003, 2005b.

Bates, N. R., Moran, S. B., Hansell, D. A., and Mathis, J. T.: An increasing $\mathrm{CO}_{2}$ sink in the Arctic Ocean due to sea-ice loss?, Geophys. Res. Lett., 33, L23609, doi:10.1029/2006GL027028, 
2006.

Bates, N. R., Mathis, J. T., and Cooper, L.: The effect of ocean acidification on biologically induced seasonality of carbonate mineral saturation states in the Western Arctic Ocean, J. Geophys. Res.Oceans, 114, C11007, doi:10.1029/2008JC004862, 2009.

Bates, N. R., Amat, A., and Andersson, A. J.: Feedbacks and responses of coral calcification on the Bermuda reef system to seasonal changes in biological processes and ocean acidification, Biogeosciences, 7, 2509-2530, doi:10.5194/bg-7-25092010, 2010.

Bates, N. R., Mathis, J. T., and Jeffries, M. A.: Air-sea $\mathrm{CO}_{2}$ fluxes on the Bering Sea shelf, Biogeosciences, 8, 1237-1253, doi:10.5194/bg-8-1237-2011, 2011a.

Bates, N. R., Cai, W.-J., and Mathis, J. T.: The ocean carbon cycle in the western Arctic Ocean: Distributions and air-sea fluxes of carbon dioxide $\left(\mathrm{CO}_{2}\right)$, Oceanography, 24, 186-201, doi:10.5670/oceanog.2011.71, 2011.71, 2011 b.

Bates, N. R., Best, M. H. P., Neely, K., Garley, R., Dickson, A. G., and Johnson, R. J.: Detecting anthropogenic carbon dioxide uptake and ocean acidification in the North Atlantic Ocean, Biogeosciences, 9, 2509-2522, doi:10.5194/bg-9-2509-2012, 2012.

Brewer, P. G. and Goldman, J. C.: Alkalinity changes generated by phytoplankton growth, Limnol. Oceanogr., 21, 108-117, 1976.

Buddemeier, R. W., Kleypas, J. A., and Aronson, R. B.: Coral Reefs and Global Climate Change: Potential Contributions of Climate Change to Stresses on Coral Reef Ecosystems, p. 44, (download report at http://www.c2es.org/docUploads/Coral_ Reefs.pdf), Pew Center on Climate Change, (last access: 29 July 2013), 2004.

Büdenbender, J., Riebesell, U., and Form, A., Calcification of the Arctic coralline red algae Lithothamnion glaciale in response to elevated $\mathrm{CO}_{2}$, Mar. Ecol.-Prog. Ser., 441, 79-87, 2011.

Butler, J. N.: Carbon dioxide equilibria and their applications. Addison-Wesley, Michigan, 255 pp., 1982.

Byrne, R. H., Mecking, S., Feely, R. A., and Liu, X. W.: Direct observations of basin-wide acidification of the North Pacific Ocean, Geophys. Res. Lett., 37, L02601, doi:10.1029/2009GL040999, 2010.

Cai, W.-J., Chen, L., Chen, B., Gao, Z., Lee, S.H., Chen, J., Pierrot, D., Sullivan, K., Wang, Y., Hu, X., Huang, W.-J., Zhang, Y., Xu, S., Murata, A., Grebmeier, J. M., Jones, E. P., and Zhang, H.: Decrease in the $\mathrm{CO}_{2}$ uptake capacity in an ice-fee Arctic Ocean basin, Science, 329, 556, doi:10.1126/science.1189338, 2010.

Cai, W. J., Bates, N. R., Guo, L., Anderson, L. G., Mathis, J., Wanninkhof, R., Hansell, D. A., Chen, L., and Semiletov, I., Carbon Fluxes across Boundaries in the Pacific Sector of the Arctic Ocean in a Changing Environment, in: The Pacific Arctic Sector: Status and Trends, edited by: Grebmeier, J. M., Maslowski, W., and Zhao, J., Springer, in press, 2013.

Caldeira, K. and Wickett, M. E.: Anthropogenic carbon and ocean pH, Nature, 425, 365-368, 2003.

Caldeira, K. and Wickett, M. E.: Ocean model predictions of chemistry changes from carbon dioxide emissions to the atmosphere and ocean, J. Geophys. Res.-Oceans, 110, C09S04, doi:10.1029/2004JC002671, 2005.

Carmack, E. and Wassman, P.: Food webs and physical-biological coupling on pan-Arctic shelves: Unifying concepts and comprehensive perspectives, Prog. Oceanogr., 71, 446-477, 2006.
Cauwet, G. and Siderov, I.: The biogeochemistry of Lena River: Organic carbon and nutrients distribution, Mar. Chem., 53, $211-$ 227, 1996.

Cavalieri, D., Parkinson, C., Gloersen, P., and Zwally, H. J.: Sea Ice Concentrations from Nimbus-7 SMMR and DMSP SSM/ISSMIS Passive Microwave Data, [2009, 2010, 2011 monthly climatology], Boulder, Colorado USA, National Snow and Ice Data Center, 1996, updated yearly.

Chen, C. T. A. and Borges, A. V.: Reconciling opposing views on carbon cycling in the coastal ocean: Continental shelves as sinks and near-shore ecosystems as sources of atmospheric $\mathrm{CO}_{2}$, Deep-Sea Res. Pt. II, 56, 578-590, 2009.

Chierici, M. and Fransson, A.: Calcium carbonate saturation in the surface water of the Arctic Ocean: undersaturation in freshwater influenced shelves, Biogeosciences, 6, 2421-2431, doi:10.5194/bg-6-2421-2009, 2009.

Comeau, S., Gorsky, G., Jeffree, R., Teyssié, J.-L., and Gattuso, J.-P.: Impact of ocean acidification on a key Arctic pelagic mollusc (Limacina helicina), Biogeosciences, 6, 1877-1882, doi:10.5194/bg-6-1877-2009, 2009.

Cooper, L. W., Whitledge, T. E., Grebmeier, J. M., and Weingartner, T., The nutrient, salinity, and stable oxygen isotope composition of Bering and Chukchi Seas waters in and near the Bering Strait, J. Geophys. Res., 102, 12563-12573, 1997.

Denman, K. L. and Gargett, A. E.: Time and space scales of vertical mixing and advection of phytoplankton in the upper ocean, Limnol. Oceanogr., 28, 801-815, 1983.

Dickson, A. G. and Millero, F. J.: A comparison of the equilibrium constants for the dissociation of carbonic acid in seawater media, Deep Sea Res. Pt. A, 34, 1733-174, 1987.

Dickson, A. G., Sabine, C. L., and Christian, J. R.: Guide to best practices for ocean $\mathrm{CO}_{2}$ measurements, PICES Special Publication 3, (International Ocean Carbon and Climate Project) IOCCP Report no. 8, 2007, North Pacific Marine Science Organization, Seattle, 2007.

Doney, S. C., Fabry, V. J., Feely, R. A., and Kleypas, J. A.: Ocean acidification: the other $\mathrm{CO}_{2}$ problem, Ann. Rev. Mar. Sci., 1, 169-192, doi:10.1146/annurev.marine.010908.163834, 2009.

Dore, J. E., Lukas, R., Sadler, D. W., Church, M. J., and Karl, D. M.: Physical and biogeochemical modulation of ocean acidification in the central North Pacific, P. Natl. Acad. Sci. USA, 106, 1223512240, doi:10.1073/pnas.0906044106, 2009.

Emery, W. J.: Water types and water masses, in: Water Circulation, Elsevier Science, London, 2003.

Fabry, V. J., Seibel, B. A., Feely, R. A., and Orr, J. C.: Impacts of ocean acidification on marine fauna and ecosystem processes, ICES J. Mar. Sci., 65, 414-432, doi:10.1093/icesjms/fsn048, 2008.

Fassbender, A. J., Sabine, C. L., Feely, R. A., Langdon, C., and Mordy, C. W.: Inorganic carbon dynamics during northern California coastal upwelling. Cont. Shelf Res., 31, 1180-1192, doi:10.1016/j.csr.2011.04.006, 2011.

Feely, R. A., Byrne, R. H., Acker, J. G., Betzer, P. R., Chen, C. T.A., Gendron, J. F., and Lamb, M. F.: Winter summer variations of calcite and aragonite saturation in the Northeast Pacific, Mar. Chem., 25, 227-241, doi:10.1016/0304-4203(88)90052-7, 1988.

Feely, R. A., Sabine, C. L., Lee, K., Berelson, W., Kleypas, J., Fabry, V. J., and Millero, F. J.: Impact of anthropogenic $\mathrm{CO}_{2}$ on the $\mathrm{CaCO}_{3}$ system in the oceans, Science, 305, 362-366, 
doi:10.1126/science.1097329, 2004.

Feely, R. A., Sabine, C. L., Hernandez-Ayon, J. M., Ianson, D., and Hales, B.: Evidence for upwelling of corrosive "acidified" water onto the continental shelf, Science, 320, 1490-1492, doi:10.1126/science.1155676, 2008.

Feely, R. A., Doney, S. C., and Cooley, S. R.: Ocean acidification: Present and future changes in a high- $\mathrm{CO}_{2}$ world, Oceanography, 22, 36-47, 2009.

Feely, R. A., Alin, A. R., Newton, J. R., Sabine, C. L., Warner, M., Devol, A., Krembs, C., and Maloy, C.: The combined effects of ocean acidification, mixing, and respiration on $\mathrm{pH}$ and carbonate saturation in an urbanized estuary, Estuar. Coast. Shelf S., 88, 442-449, doi:10.1016/j.ecss.2010.05.004, 2010.

Fransson, A., Chierici, M., and Nojiri, Y.: New insights into the spatial variability of the surface water carbon dioxide in varying sea ice conditions in the Arctic Ocean, Cont. Shelf Res., 29, 13171328, doi:10.1016/j.csr.2009.03.008, 2009.

González-Dávila, M., Santana-Casiano, J. M., Rueda, M. J., and Llinás, O.: The water column distribution of carbonate system variables at the ESTOC site from 1995 to 2004, Biogeosciences, 7, 3067-3081, doi:10.5194/bg-7-3067-2010, 2010.

Grebmeier, J. M., Bates, N. R., and Devol, A.: Continental Margins of the Arctic Ocean and Bering Sea, in: North American Continental Margins: A Synthesis and Planning Workshop, edited by: Hales, B., Cai., W.-J., Mitchell, B. G., Sabine, C. L., and Schofield, O., US Carbon Cycle Science Program, Washington DC, 61-72, 2008.

Hill, V. and Cota, G.: Spatial patterns of primary production on the shelf, slope and basin of the western Arctic in 2002, DeepSea-Res. Pt. II, 52, 3344-3354, doi:10.1016/j.dsr2.2005.10.001, 2005.

Jutterström, S. and Anderson, L. G.: The saturation of calcite and aragonite in the Arctic Ocean, Mar. Chem., 94, 101-110, 2005.

Jutterström, S. and Anderson, L. G.: Uptake of $\mathrm{CO}_{2}$ by the Arctic Ocean in a changing climate, Mar. Chem., 122, 96-104, 2010.

Kaltin, S. and Anderson, L. G.: Uptake of atmospheric carbon dioxide in Arctic shelf seas: evaluation of the relative importance of processes that influence $p \mathrm{CO}_{2}$ in water transported over the Bering-Chukchi Sea shelf, Mar. Chem., 94, 67-79, 2005.

Kattner, G., Lobbes, J. M., Fitznar, H. P., Engbrodt, R., Nothig, E. M., and Lara, R. J.: Tracing dissolved organic substances and nutrients from the Lena River through Laptev Sea (Arctic), Mar. Chem., 65, 25-39, doi:10.1016/S0304-4203(99)00008-0, 1999.

Khatiwala, S., Primeau, F., and Hall, T.: Reconstruction of the history of anthropogenic $\mathrm{CO}_{2}$ concentration in the ocean, Nature, 462, 346-347, doi:10.1038/nature08526, 2009.

Lischka, S., Büdenbender, J., Boxhammer, T., and Riebesell, U.: Impact of ocean acidification and elevated temperatures on early juveniles of the polar shelled pteropod Limacina helicina: mortality, shell degradation, and shell growth, Biogeosciences, 8, 919-932, doi:10.5194/bg-8-919-2011, 2011.

Macdonald, R. W., McLaughlin, F. A., and Carmack, E. C.: Fresh water and its sources during the SHEBA drift in the Canada Basin of the Arctic Ocean, Deep-Sea Res., 49, 1769-1785, doi:10.1016/S0967-0637(02)00097-3, 2002.

Manizza M., Follows, M. J., Dutkiewicz, S., Menemenlis, D., McClelland, J. W., Hill, C. N., Peterson, B. J., and Key, R. M.: A model of Arctic Ocean carbon cycle, J. Geophys. Res., 116, in press, 2013.
Maslanik, J. A., Drobo, S., Fowler C., Emery, W., and Barry R.: On the Arctic climate paradox and the continuing role of atmospheric circulation in affecting sea ice conditions, Geophys. Res. Lett., 34, L03711, doi:10.1029/2007GL032043, 2007.

Mathis, J. T. and Bates, N. R.: The marine carbon cycle of the Arctic Ocean: Some thoughts about the controls on air-sea $\mathrm{CO}_{2}$ exchanges and responses to ocean acidification, Ocean Carbon and Biogeochemistry (OCB) News, 3, 1-5, spring/summer 2010.

Mathis, J. T., Bates, N. R., Hansell, D. A., and Babila, T.: Net community production in the northeastern Chukchi Sea, DeepSea Res. Pt. II, 56, 1213-1222, doi:10.1016/j.dsr2.2008.10.017, 2009.

Mathis, J. T., Cross, J. N., Bates, N. R., Bradley Moran, S., Lomas, M. W., Mordy, C. W., and Stabeno, P. J.: Seasonal distribution of dissolved inorganic carbon and net community production on the Bering Sea shelf, Biogeosciences, 7, 1769-1787, doi:10.5194/bg-7-1769-2010, 2010.

Mathis, J. T., Cross, J., and Bates, N. R.: The role of ocean acidification in systemic carbonate mineral suppression in the Bering Sea, Geophys. Res. Lett., 39, L19602, doi:10.1029/2011GL048884, 2011a.

Mathis, J. T., Cross, J., and Bates, N. R.: Coupling primary production and terrestrial runoff to ocean acidification and carbonate mineral suppression in the eastern Bering Sea, Global Biogeochem. Cy., 116, C02030, doi:10.1029/2010JC006453, 2011 b.

Mathis, J. T., Pickart, R. S., Byrne, R. H., McNeil, C. L., Moore, G. W. K., Juranek, L. W., Liu, X. W., Ma, J., Easley, R. A., Elliot, M. M., Cross, J. N., Reisdorph, S. C., Bahr, F., Morison, J., Lichendorf, T., and Feely, R. A.: Storm-induced upwelling of high $p \mathrm{CO}_{2}$ waters onto the continental shelf of the western Arctic Ocean and implications for carbonate mineral saturation states, Geophys. Res. Lett., 39, L07606, doi:10.1029/2012GL051574, 2012.

McGuire, A. D., Chapin, F. S., Walsh, J. E., and Wirth, C.: Integrated regional changes in arctic climate feedbacks: implications for the global climate system, Annu. Rev. Env. Resour., 31, 6191, 2006.

McGuire, A. D., Anderson, L., Christensen, T. R., Dallimore, S., Guo, L. D., Hayes, D., Heimann, M., Macdonald, R., and Roulet, N.: Sensitivity of the carbon cycle in the Arctic to climate change (Review), Ecol. Monogr., 79, 523-555, 2009.

Mehrbach, C., Culberson, C. H., Hawley, J. E., and Pytkowicz, R. M.: Measurement of the apparent dissociation constants of carbonic acid in seawater at atmospheric pressure, Limnol. Oceanogr., 18, 897-907, 1973.

Moran, S. B., Kelly, R. P., Hagstrom, K., Smith, J. N., Grebmeier, J. M., Cooper, L. W., Cota, G. F., Walsh, J. J., Bates, N. R., Hansell, D. A., Maslowski, W., Nelson, R. P., and Mulsow, S.: Seasonal changes in POC export flux in the Chukchi Sea and implications for water column-benthic coupling in Arctic shelves, Deep-Sea Res., 52, 3427-3451, doi:10.1016/j.dsr2.2005.09.011, 2005.

Murata, A. and Takizawa, T.: Summertime $\mathrm{CO}_{2}$ sinks in shelf and slope waters of the western Arctic Ocean, Cont. Shelf Res., 23, 753-776, 2003.

Olafsson, J., Olafsdottir, S. R., Benoit-Cattin, A., Danielsen, M., Arnarson, T. S., and Takahashi, T.: Rate of Iceland Sea acidification from time series measurements, Biogeosciences, 6, 26612668, doi:10.5194/bg-6-2661-2009, 2009. 
Orr, J. C., Fabry, V. J., Aumont, O., Bopp, L., Doney, S. C., Feely, R. A., Gnanadesikan, A., Gruber, N., Ishida, A., Joos, F., Key, R. M., Lindsay, K., Maier-Reimer, E., Matear, R., Monfray, P., Mouchet, A., Najjar, R. G., Plattner, G.-K., Rodgers, K. B., Sabine, C. L, Sarmiento, J. L., Schlitzer, R., Slater, R. D., Totterdell, I., Weirig, M.-F., Yamanaka, Y., and Yool, A.: Anthropogenic ocean acidification over the twenty-first century and its impacts on calcifying organisms, Nature, 437, 681-686., 2005.

Pabi, S., van Dijken, G. L., and Arrigo, K. R.: Primary production in the Arctic Ocean, 1998-2006, J. Geophys. Res., 113, C08005, doi:10.1029/2007JC004578, 2008.

Pipko, I. I., Semiletov, I. P., Pugach, S. P., Wåhlström, I., and Anderson, L. G.: Interannual variability of air-sea $\mathrm{CO}_{2}$ fluxes and carbon system in the East Siberian Sea, Biogeosciences, 8, 19872007, doi:10.5194/bg-8-1987-2011, 2011.

Ries, J. B.: Skeletal mineralogy in a high- $\mathrm{CO}_{2}$ world, J. Exp. Mar. Biol. Ecol., 403, 54-64, 2011

Robbins, L. L. Hansen, M. E., Kleypas, J. A., and Meylan, S. C.: CO2calc: a user-friendly seawater carbon calculator for Windows, Max OS X, and iOS (iPhone), US Geological Survey Open-File Report, 2010-1280, 1-17, http://pubs.usgs.gov/ of/2010/1280/, (last access: July 2013), 2010.

Sabine, C. L., Feely, R. A., Gruber, N., Key, R. M., Lee, K., Bullister, J. L., Wanninkhof, R., Wong, C.S., Wallace, D. W. R., Tilbrook, B., Millero, F. J., Peng, T. H., Kozyr, A., Ono, T., and Rios, A. F.: The oceanic sink for anthropogenic $\mathrm{CO}_{2}$, Science, 305, 367-371, 2004.

Santana-Casiano, J. M., Gonzalez-Davila, M., Rueda, M.-J., Llinas, O., and Gonzalez-Davila, E.-F.: The interannual variability of oceanic $\mathrm{CO}_{2}$ parameters in the western Atlantic subtropical gyre at the ESTOC site, Global Biogeochem. Cy., 21, GB1015, doi:10.1029/2006GB002788, 2007.

Schlitzer, R.: Ocean Data View, http://odv.awi.de, (last access: 5 May 2012), 2011.

Semiletov, I. P.: Aquatic sources of $\mathrm{CO}_{2}$ and $\mathrm{CH}_{4}$ in the Polar regions, J. Atmos. Sci., 56, 286-306, 1999.

Semiletov, I., Makshtas, A., Akasofu, S. I., and Andreas, E. L.: Atmospheric $\mathrm{CO}_{2}$ balance: the roles of Arctic sea ice, Geophys. Res. Lett., 31, L05121, doi:10.1029/2003GL017996, 2004.

Semiletov, I., Pipko, I., Repina, I., and Shakhova, N. E.: Carbonate chemistry dynamics and carbon dioxide fluxes across the atmosphere-ice-water interfaces in the Arctic Ocean: Pacific sector of the Arctic, J. Marine Syst., 66, 204-226, 2007.

Serreze, M. C. and Francis, J. A.: The Arctic amplification debate, Climate Change, 76, 241-264, 2006.

Smith, A. M.: Bryozoans as southern sentinels of ocean acidification: a major role for a minor phylum, Mar. Freshwater Res., 60, 475-482, 2009.
Solomon, S., Qin, D., Manning, M., Chen, Z., Marquis, M., Averyt, K. B., Tignor, M., and Miller, H. L. (Eds.): Contribution of Working Group I to the Fourth Assessment Report of the Intergovernmental Panel on Climate Change, 2007, Cambridge University Press, Cambridge, UK and New York, NY, USA, 2007.

Steinacher, M., Joos, F., Frölicher, T. L., Plattner, G.-K., and Doney, S. C.: Imminent ocean acidification in the Arctic projected with the NCAR global coupled carbon cycle-climate model, Biogeosciences, 6, 515-533, doi:10.5194/bg-6-515-2009, 2009.

Tanhua, T., Jones, E. P., Jeansson, E., Jütterstrom, S., Smethie, W.M. Wallace, D. W. R., and Anderson, L. G.: Ventilation of the Arctic Ocean: Mean ages and inventories of anthropogenic $\mathrm{CO}_{2}$ and CFC-11, J. Geophys. Res., 114, C01002, doi:10.1029/2008JC004868, 2009.

Tanhua, T., Bates, N. R., and Kortzinger, A.: The marine carbon Cycle and ocean carbon inventories, edited by: Church J. and G. Seidler, Springer-verlag, New York, in press, 2013.

Walther, G.-R.: Community and ecosystem responses to recent climate change, Philos. T. R. Soc. B, 365, 2019-2024, 2010.

Walther, K., Sartoris, F. J., Bock, C., and Pörtner, H. O.: Impact of anthropogenic ocean acidification on thermal tolerance of the spider crab Hyas araneus, Biogeosciences, 6, 2207-2215, doi:10.5194/bg-6-2207-2009, 2009.

Wang, M. Y. and Overland, J. E.: A sea-ice free summer Arctic within 30 years?, Geophys. Res. Lett., 36, L07502, doi:10.1029/2009GL037820, 2009.

Wanninkhof, R.: Relationship between wind speed and gas exchange over the ocean, J. Geophys. Res.-Oceans, 97, 7373-7382, 1992.

Weingartner, T. J.: The Siberian Coastal Current: A wind- and buoyancy-forced Arctic coastal current, J. Geogr. Res., 104, 29697-29713, 1999.

Woodgate, R. A. and Aagaard, K.: Revising the Bering Strait freshwater flux into the Arctic Ocean, Geophys. Res. Lett., 32, L02602, doi:10.1029/2004GL021747, 2005.

Woodgate, R. A., Aagaard, K., and Weingartner, T. J.: Monthly temperature, salinity and transport variability of the Bering Strait through flow, Geophys. Res. Lett., 32, L04601, doi:10.1029/2004GL021880, 2005.

Yamamoto-Kawai, M., McLaughlin, F. A., Carmack, E. C., Nishino, S., and Shimada, K.: Aragonite undersaturation in the Arctic Ocean: effects of ocean acidification and sea ice melt, Science, 326, 1098-1100, doi:10.1126/science.1174190, 2009. 